UNIVERSIDADE DE SÃO PAULO

ESCOLA DE COMUNICAÇÕES E ARTES

PROGRAMA DE PÓS-GRADUAÇÃO EM ARTES VISUAIS

LÍNGUA

Morta

ANA LUIZA DIAS

BATISTA

SÃO PAULO

2014 
UNIVERSIDADE DE SÃO PAULO

ESCOLA DE COMUNICAÇÕES E ARTES

PROGRAMA DE PÓS-GRADUAÇÃO EM ARTES VISUAIS

\section{LÍNGUA MorTA}

ANA LUIZA DIAS

BATISTA

Tese apresentada ao Programa de Pós-Graduação em Artes Visuais da Escola de Comunicações e Artes da Universidade de São Paulo, como requisito parcial para obtenção do título de Doutor em Artes Visuais. Orientadora: Profa. Dra. Sônia Salzstein Goldberg.

SÃO PAULO

2014 


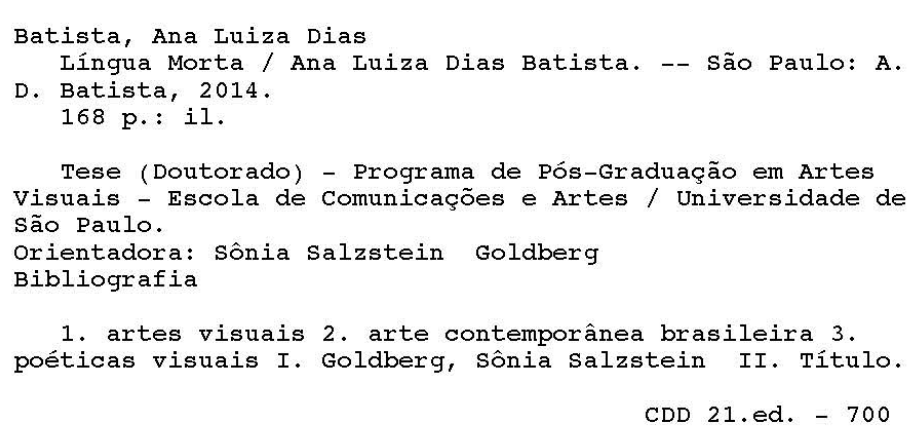


Agradeço ao João, à Maria do Carmo, ao Nildo, à Silvia, à Mariana e à Clara. À Sônia. À Liliane e ao Cadu. 
O objeto desta tese são os trabalhos de arte da autora. Eles são agrupados segundo critérios provisórios de identidade, que se constituem e explicitam nas próprias formas dos textos e imagens que os acompanham. Buscam-se elementos comuns, simétricos ou proporcionais nos trabalhos, procedimentos comuns, confluentes ou paralelos, correspondências formais. A abordagem é descritiva. A passagem entre os trabalhos se dá diretamente, sem conexões explicativas, por acareação. Pretende-se construir, na dimensão da linguagem, lugares de coexistência, chãos comuns onde os trabalhos se possam dispor, espaços transitórios que permitam arranjá-los.

PALAVRAS-CHAVE: artes visuais; arte contemporânea brasileira; poéticas visuais 
The object of this thesis is the author's works of art. They are grouped according to contingent criteria of identity, which constitute and explicit themselves in the very forms of texts and adjoining images. The author searches among the works for common, symmetrical or proportional elements, common, confluent or parallel procedures, formal correspondences. The approach is descriptive. The transition between the works is deprived of explanatory connections; they face each other directly, in line-up confrontation. The intention is to build, in the dimension of language, sites of coexistence, common grounds where the works can lay, transitory spaces that allow to arrange them.

KEY-WORDS: visual arts; Brazilian contemporary art; visual poetics 
SUMÁRIO

1 Sem título

2 O FIM

3 Numerador E DENOMinAdor

4 O DIA DO JABUTI

5 O CENTRO

6 O Que É, O QUE É? SEU NúCLEO É CONSTITUÍDO DE FERRO,

NíQUEL E TALVEZ ENXOFRE

7 RuíDO BRANCO

8 Vício De LINGUAGEM

9 IMPLICAÇÃO MÚtUA

10 SEQUÊNCIA

11 ESOTERISMO

12 Sistema digestivo

13 Sem título

14 Bibliografia ANOTADA 
Olhar todos os meus trabalhos, ou imagens deles, com o máximo distanciamento possível. Tentar enxergá-los como objetos emancipados. Encará-los de supetão, sem memória. Observar procedimentos, processos de formalização, fisionomia, modos de operação, sentido. Notar recorrências, analogias, correspondências, derivações. Associar provisoriamente, agrupar.

Passar à redação. Evitar interpretações e tomar tudo literalmente. Descrever os trabalhos, trazê-los ao primeiro plano ${ }^{1}$, seguindo sua disciplina. Dispôlos em chãos comuns, espaços que permitam ordená-los, construídos na dimensão da linguagem. Manejar as palavras com cuidado. Interromper, inverter, reiterar, repetir. Apropriar-se de "certa ética da linguagem literária, que deve ser afirmada porque ela é contestada" ${ }^{2}$. Evitar as passagens explicativas, as relações causais, cotejar qualidades, acarear.

Selecionar ou produzir imagens, confrontá-las ao texto, confrontá-las aos trabalhos. Testar sua suficiência e sua necessidade. Mostrar de novo, mostrar menos.

\author{
A ideia de que descrever é "trazer \\ para o primeiro plano" é de Philippe \\ Hamon: "A descrição não é cópia realista \\ utópica adequação a uma realidade, \\ sim uma racionalização 'a posteriori' \\ permanentemente em busca de um \\ vocabulário metafórico." O que é um \\ descrição. In: Categorias da narrativa. Lisboa:
}

Vega, 1991, p. 57.Ver:TAMARO, Angela Harumi. A descrição na literatura e no cinema. Pro-posições, vol. 10, n. 1, março de 1999.

${ }^{2}$ Barthes deriva essa ética da disposição de "mudar a língua” em Mallarmé. Ver: Aula. São Paulo: Cultrix, 1997, p. 24. 
menos, dizer de novo.

Voltar aos trabalhos, verificar os efeitos coercivos do conjunto. Voltar ao texto, voltar às imagens, voltar aos trabalhos. Equilibrar-se no limiar entre falta e excesso, cair de novo, cair melhor ${ }^{3}$.

Intitular os capítulos, circunscrevendo seus movimentos formais num campo semântico ${ }^{4}$, sem pretender traduzi-los

Intitular a tese.

3 "Ever tried. Ever failed. No matter. Try again. Fail again. Fail better”. Samuel Beckett, em Worstward Ho. Apud BENETTI, Liliane. Ângulos de uma caminhada lenta: exercícios de contenção, reiteração e saturação na obra de Bruce Nauman. São Paulo, 2013, p. 139. Tese de Doutorado. Escola de Comunicações e Artes da Universidade de São Paulo.

${ }^{4}$ Michel Foucault, em As palavras e as coisas: "Parece que certos afásicos não chegam a classificar de maneira coerente as meadas sobre a superfície de uma mesa; como se esse retângulo unificado não pudesse servir de espaço homogêneo e neutro onde as coisas viessem ao mesmo tempo manifestar a ordem contínua de suas identidades ou de suas diferenças e o campo semântico de sua denominação. Eles formam, nesse

espaço unido, onde as coisas normalmente se distribuem e se nomeiam, uma multiplicidade de pequenos domínios granulosos e

fragmentários onde semelhanças sem nome glutinam as coisas em ilhotas descontinu ium canto, colocim as meadas mais car noutro, as vermelhas, aqui, aquelas que têm uma consistência mais lanosa, ali, aquelas mais longas, ou as que tendem ao violeta, ou as que foram enroladas em novelo. Mas, mal são esboçados, todos esses agrupamentos se desfazem, pois a orla de identidade que os sustenta, por mais estreita que seja, é aind demasiado extensa para não ser instável; e, infinitamente, o doente reúne e separa, amontoa similitudes diversas, destrói as mais evidentes, dispersa as identidades, superpõe critérios diferentes, agita-se, recomeça, inquieta-se e chega finalmente à beira da angústia." São Paulo: Martins Fontes, 2000, p. XIII.
Montado em 2008, num pequeno espaço na sobreloja de um sebo no bairro da Liberdade, em São Paulo , "Continuação" foi feito com uma mangueira luminosa vermelha de aproximadamente 50 metros, ligada a um sequenciador e programada para piscar alternadamente em ritmo constante. A mangueira foi instalada junto ao rodapé no primeiro degrau da escada que conduzia do sebo à sobreloja, desdobrando-se nos degraus sucessivos. No primeiro andar, a mangueira contornava o batente de uma porta fechada à direita, dobrava-se 90 graus junto à quina e seguia, sempre adjacente ao rodapé, por um corredor estreito que levava à sala central. Ali, a mangueira dava uma volta completa no espaço, percorrendo as paredes e retornando ao limiar da passagem pela qual tinha entrado, para, então, subir pelo batente, dobrar à esquerda e formar, torcendo-se, uma palavra, saída. 
O espaço era truncado: a escada estreita e irregular; no pequeno hall, a porta fechada à direita; atrás, um corredorzinho separado do vão da escada por uma balaustrada de metal; duas outras portas fechadas; o corredor também muito estreito levando à sala principal; pé direito baixo, vigas atravessando o forro. No centro da sala, um recorte quadrado na laje através do qual se via o sebo e outra balaustrada de metal; à direita, o volume da escada que vinha da rua e levava ao segundo andar; uma pequena janela de correr em alumínio, com insulfilm preto, ligando essa sala a uma das salinhas atrás das portas fechadas; a parede do fundo em ângulo, acompanhando a fachada, com dois janelões de vidro voltados para a rua. Tudo gasto, usado, como os livros em fila no andar de baixo. E algo de labiríntico.

Duas serventias usuais da mangueira luminosa: orientar deslocamentos de pessoas em espaços de grande circulação e realçar vitrines comerciais, chamando atenção para produtos expostos. Em “Continuação”, a mangueira orientava o deslocamento e realçava o espaço. Mas ali não havia grande circulação, nem produtos, nem vitrines.

O último esquete do vídeo "Programa", realizado em 2007, no meu projeto de mestrado, é um plano fixo no qual se vê um retângulo feito com mangueira luminosa - amarela, desta vez. Dada a resistência do material, o retângulo obtido não é simétrico; seus cantos são arredondados e as arestas irregulares. O enquadramento é fechado na mangueira, que ocupa as extremidades da imagem.

O tamanho real do retângulo filmado coincide com as dimensões internas de um televisor de 29 polegadas. Assim, quando o vídeo é exibido, a mangueira faz uma espécie de mediação entre a imagem e o espaço concreto de transmissão. Mas ali não há qualquer (outra) imagem.

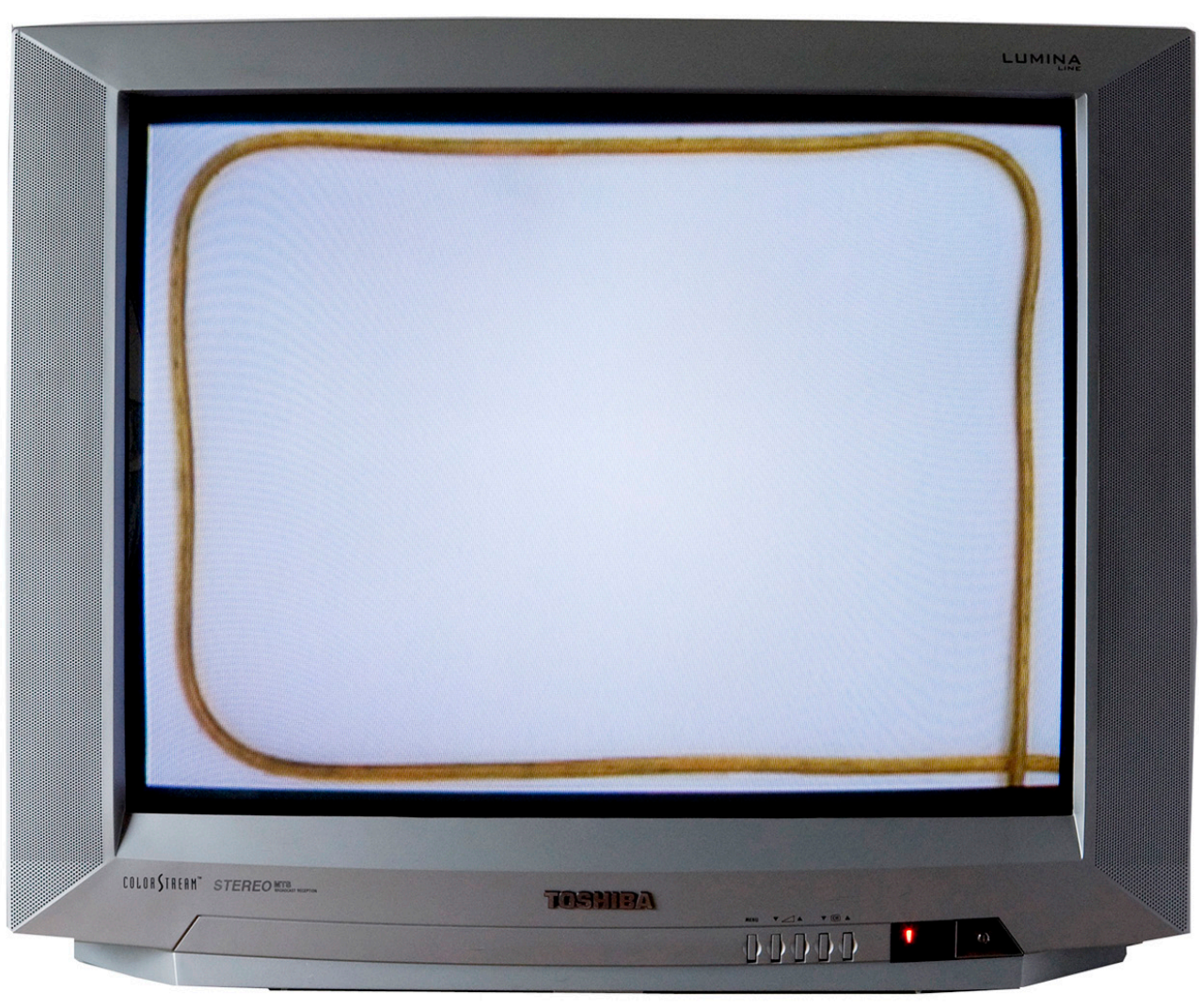

Nos primeiros segundos do esquete, todas as lâmpadas da mangueira estão apagadas. Elas se acendem simultaneamente em gradação lenta, atingindo um nível máximo de luminosidade. A partir daí, passa a diminuir a intensidade de luz, até que as lâmpadas se apagam completamente. O ruído de um reator de lâmpada fluorescente varia de intensidade numa progressão sincrônica à imagem. 
"Hipódromo" é um par de bobinas idênticas de papel monolúcido branco, de $60 \mathrm{~cm}$ de altura e $45 \mathrm{~cm}$ de diâmetro, realizado em 2009. Impressas nas bobinas, que têm aproximadamente 4000 metros de extensão cada, duas imagens se repetem alternadamente - como as lâmpadas piscantes numa mangueira de luz -, separadas por um pequeno espaço vazio - como os quadros estáticos de um filme -, a cada metro linear.

Na imagem "A" vê-se o perfil achatado de um jóquei em seu cavalo, o tronco do jóquei inclinado à frente, o cavalo com as patas projetadas, os dois fundidos em preto chapado, correndo contra o fundo branco do papel. Na base, uma faixa verde, reta embaixo, replicando o limite do papel, e ondulada em cima, aludindo às representações de terrenos gramados. A imagem "B" traz apenas essa faixa ondulada, sem jóquei-e-cavalo, “apagados”. Com seu metro exato de comprimento, a faixa verde, sozinha no quadro, marca a distância percorrida, ou a percorrer.

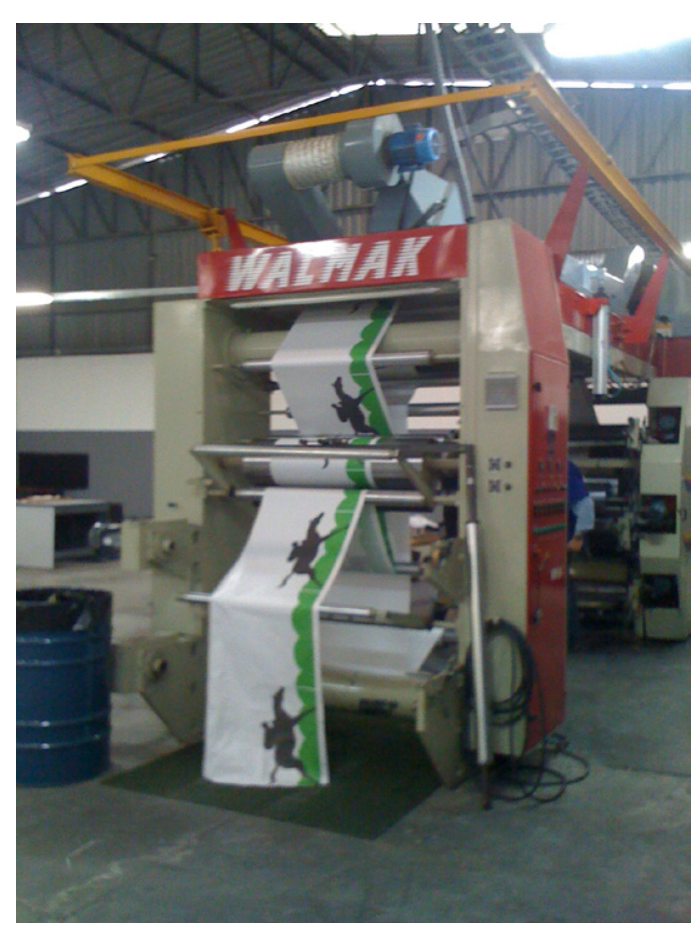

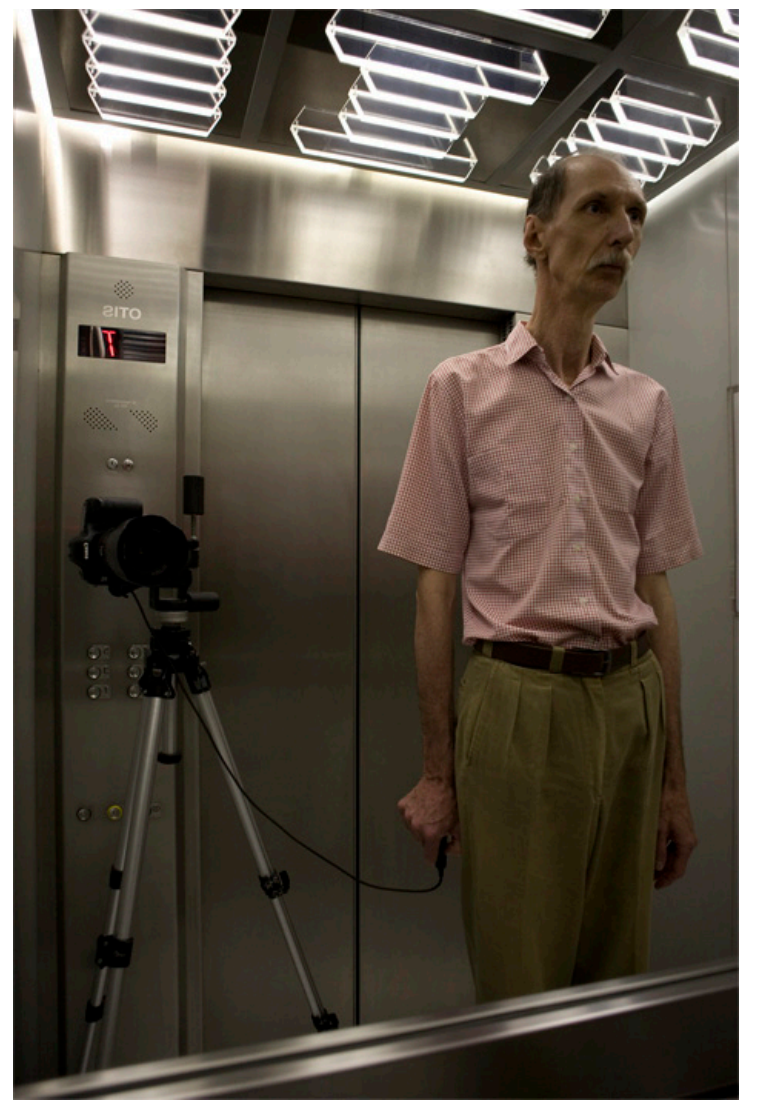

Em “O gigante”, de 2009, há um vídeo e uma imagem fotográfica. O vídeo foi filmado no terceiro andar da Estação Pinacoteca e transmitido em monitores instalados nos elevadores do museu. A foto foi tirada no elevador da Estação Pinacoteca e reproduzida nos convites da exposição que apresentei no museu.

O que mostra o vídeo transmitido no elevador: a sala no terceiro andar, vista a partir do hall de entrada, está completamente vazia. Os painéis que costumam cobrir suas janelas foram retirados. Um homem de dois metros e treze centímetros de altura, muito magro, percorre os limites do espaço, caminhando em ritmo constante, com passadas largas, contadas, como se medisse as paredes. Não há movimento de câmera. Sempre que o homem está prestes a sair do quadro, o enquadramento se modifica, num corte seco. Não 
ocorre deslocamento do ponto de vista, só oscilação panorâmica da câmera no tripé. A figura do homem diminui de tamanho à medida que ele se afasta da câmera, e aumenta quando ele volta a se aproximar. O vídeo é editado em loop. Não há som, como de resto não costuma haver nos monitores instalados em elevadores.

O que mostra a foto reproduzida no convite: o homem de dois metros e treze centímetros de altura, muito magro, e uma câmera fotográfica, montada num tripé, estão dentro do elevador. Lado a lado, ambos estão voltados para frente, e ambos miram o mesmo ponto: a imagem do homem refletida no espelho. O homem pressiona um disparador, ligado à câmera. Como a câmera não mira sua própria imagem, mas a do homem, o observador, do outro lado do espelho, não vê a cena de frente, mas de três quartos.

A mangueira luminosa em "Continuação" piscava alternadamente em ritmo regular, sugerindo um movimento progressivo, numa direção e num sentido. O visitante do sebo era incitado a segui-la escada acima, ao longo do corredor e em torno da sala, em velocidade constante. Ao mesmo tempo, a mangueira subia e descia pelos batentes, e, opondo-se à própria sugestão de fluidez, sublinhava os acidentes do espaço.

O que se encontrava no final do percurso era a mesma mangueira, submetida às mesmas ações (dobras e torções) por que vinha passando junto a rodapés e batentes, sem interrupção de continuidade. Formando, sobre a porta, a palavra "saída", ela continuava a orientar o tráfego e evidenciar o espaço, garantindo que o término da linha não significasse o fim da vigência da lógica do trabalho.
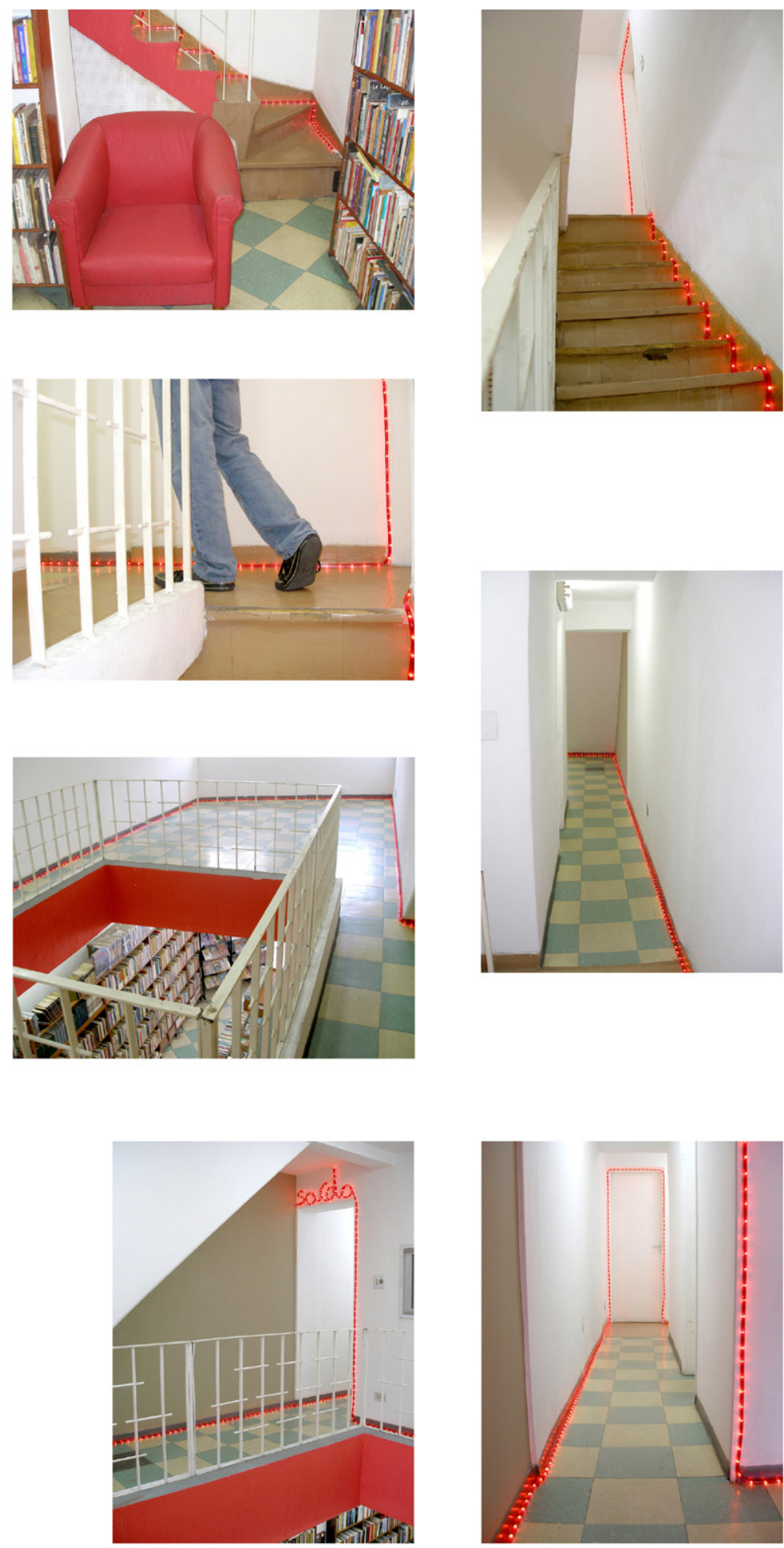
Os efeitos de transição conhecidos como fade in e fade out são recursos utilizados no processo de montagem de um filme, nos quais uma imagem aparece/ desaparece gradualmente a partir do preto total. O par fade out/ fade in, nessa ordem, é utilizado no cinema norte-americano clássico para fazer a passagem entre sequências distintas, indicando deslocamentos espaciotemporais.

O último dos seis esquetes que compõem o vídeo "Programa", editado em loop, faz a passagem entre o final e o início do conjunto. Iluminando-se e apagando-se gradualmente, inverte a ordem clássica fade out/ fade in. A transição não se realiza como efeito de pós-produção, como trucagem, mas é citada numa ação que acontece em tempo real, no momento da captação.

Caso se tratasse da trucagem, a duração dessa ação não seria percebida e, portanto, não seria contabilizada. Mas aqui parece excessiva: longos 10 segundos. A trucagem apaga a referência espaciotemporal, enquanto o trabalho ilumina literalmente os contornos do aparato. A primeira transição se dá no âmbito da história, a segunda no da exibição.

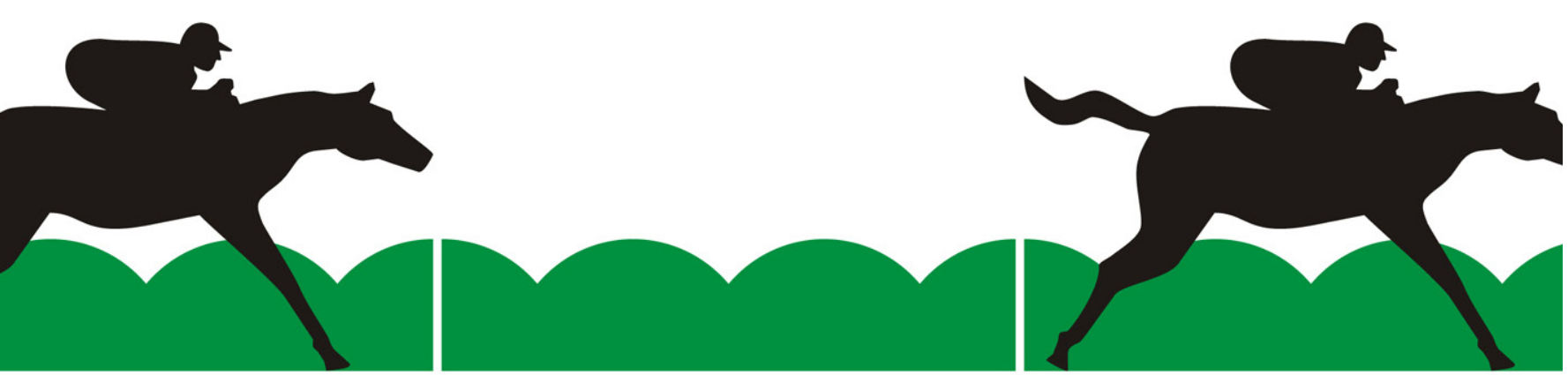

As imagens no "Hipódromo" não têm os referentes diretos que os objetos nomeados sugerem (grama, jóquei, cavalo), mas um outro, ele mesmo representação das corridas de cavalo nas pistas hípicas, elas mesmas representações dos campos naturais: os brinquedos de parques de diversões, em que jóqueis fundidos a seus cavalos, moldados em fibra e pintados numa única cor, disputam, aos soquinhos, quadro a quadro, a vitória num trajeto reto de poucos metros, de perfil para o espectador-apostador.

No vídeo transmitido no monitor instalado no elevador da Estação Pinacoteca, o visitante vê, antecipadamente, a sala que encontrará no terceiro andar. Saindo do elevador e posicionando-se na entrada dessa sala, se ele mover a cabeça em oscilação panorâmica reconhecerá os cinco enquadramentos usados no vídeo: 0 , 45, 90, 135, 180 graus. O gigante não estará mais lá.

A sala parecerá vazia, mas não estará. Haverá os trabalhos “Queimada” - um papel de parede no painel do fundo -, "Casco" - um objeto transparente sobre o piso - e "Crocante" - textura em parte da parede e das janelas da esquerda. Perto de um dos cantos será apresentado, numa tv de 29 polegadas, o vídeo "Programa". Pode ser que ele exiba, nesse momento, uma mangueira de luz amarela contornando a tela, como o gigante, antes, contornava a sala.

O pé direito da sala, baixo, por se tratar de um mezanino, parecerá mais alto aos olhos de quem o viu, há pouco, próximo à cabeça do gigante. Largura e profundidade da sala, amplas, parecerão ainda maiores, porque haviam sido percorridas, esquadrinhadas, medidas, contadas com passadas de gigante. Aliás, é possível que o próprio elevador, antecipado na foto do convite - que parece distorcida, mas não é - pareça distorcido, sem ser. 
A palavra "saída”, em "Continuação", foi escrita da direita para a esquerda, de modo que a linha termina depois do "s", e não do "a", ou seja, o fim da linha sucede o início da palavra. Para lê-la, o visitante terá que recomeçar a engajarse com a mangueira, e quem sabe segui-la do batente ao rodapé, em cada uma das paredes da sala central, ao longo do corredor estreito, em torno da porta fechada, e degrau a degrau, escada abaixo. Ou não: ele resolve apenas atravessar a passagem, ir embora, sair.

Ele não escapa à lógica do trabalho, mas nada garante que tenha, em algum momento, aderido a ela.

Em tempo: também em "Continuação" havia um convite. Ele continha as informações usuais: meu nome, nome dos organizadores, endereço do lugar, telefone, horário de visitação, escritas por um calígrafo profissional, em letra comercial inglesa, numa única linha contínua que, submetida a dobras e torções, sem interrupção de continuidade, ligava as fileiras, formando pautas.

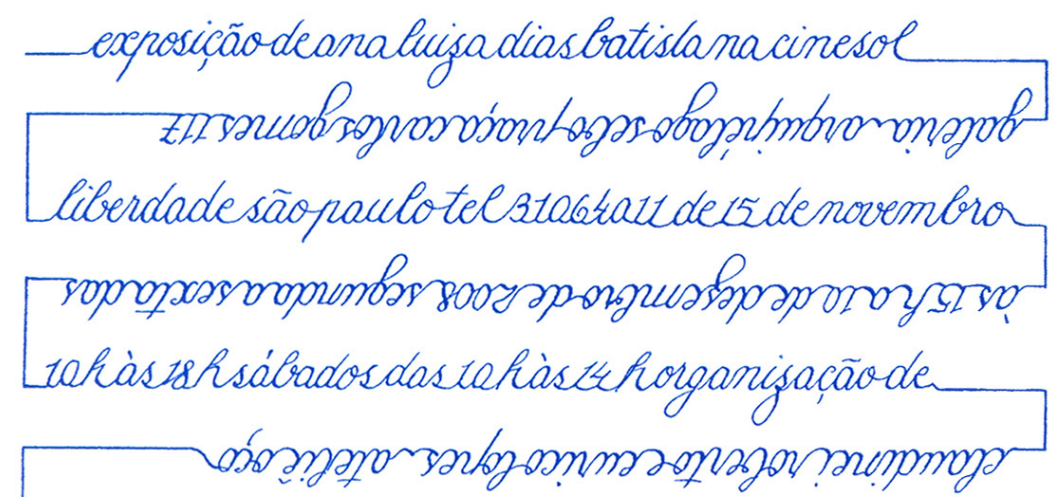

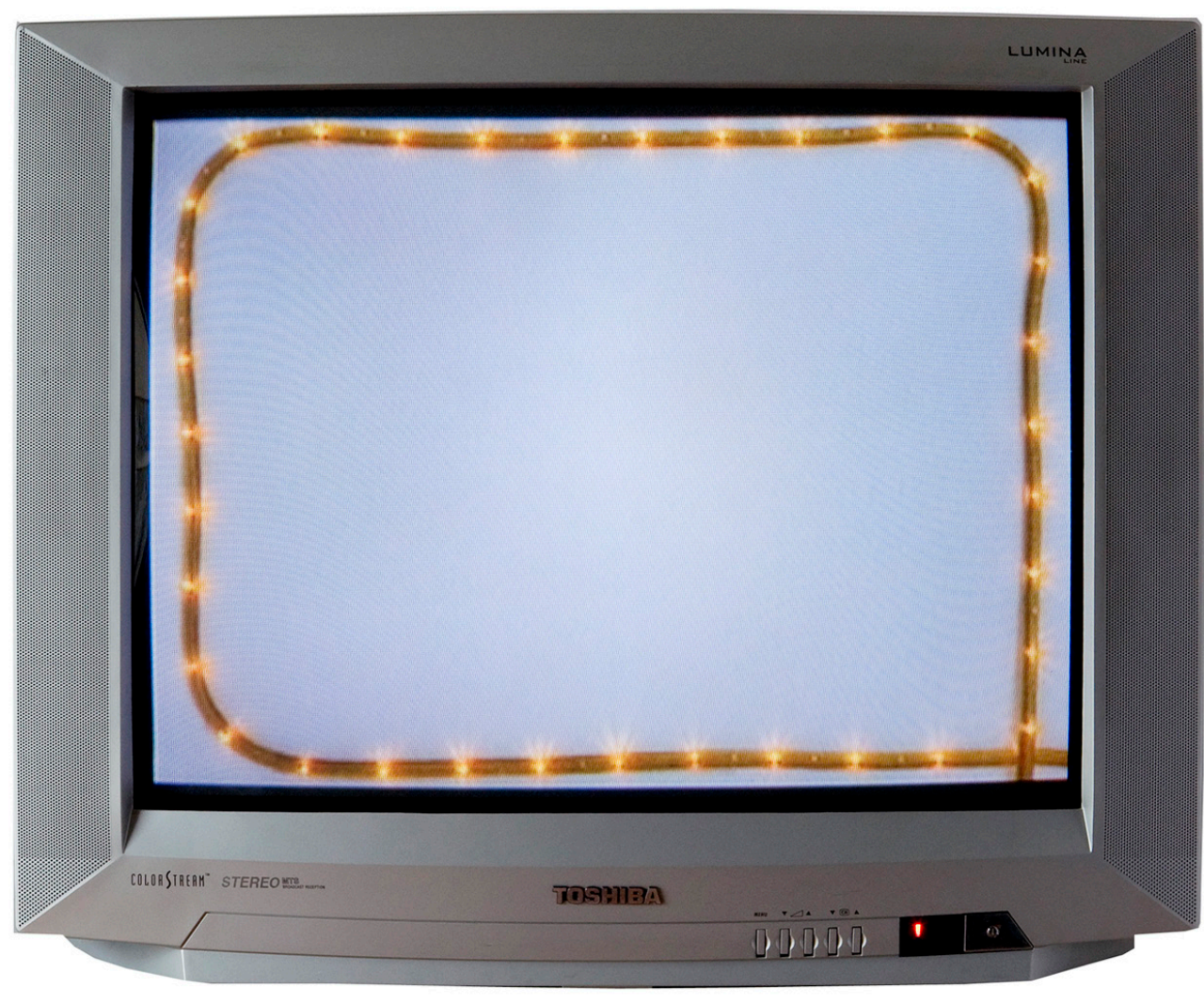

A câmera fixa e o mesmo enquadramento se mantêm no primeiro esquete de "Programa". Nele, as lâmpadas da mesma mangueira amarela, formando o mesmo retângulo impreciso, se acendem e apagam alternadamente, em alta velocidade, produzindo a impressão de um movimento progressivo, numa direção e num sentido. Por cinco segundos, as luzes correm na mangueira, com o mesmo som do reator do último esquete, agora forte e constante.

Se no último esquete ocorre algo como um movimento fechado, completo, executado sem pressa diante de uma câmera que "vê", o primeiro é um fragmento de uma ação frenética e uniforme, que poderia se prolongar indefinidamente, indiferente à captação. $\mathrm{O}$ par de esquetes com mangueira luminosa funciona como as vinhetas de encerramento e abertura do vídeo "Programa". Fim e começo, apesar do loop, ou justamente por causa dele. 
Durante a exposição de "Hipódromo", os visitantes cortam e levam trechos das bobinas, desenrolando uma e outra aos soquinhos, quadro a quadro. Nesse movimento, na mesma direção, mas em sentido oposto ao movimento virtual dos cavalos em disputa, reposiciona-se frequentemente a linha de chegada, o fim.

Se o cavalo vencedor, indiferente à torcida de espectadores-apostadores, é sempre o mesmo, é preciso considerar que o trabalho não visa o tempo da história (a história de um brinquedo de parque de diversões, que é a história de um jogo de arena, que é a história de pessoas montando cavalos em campos naturais), mas o tempo da exibição.

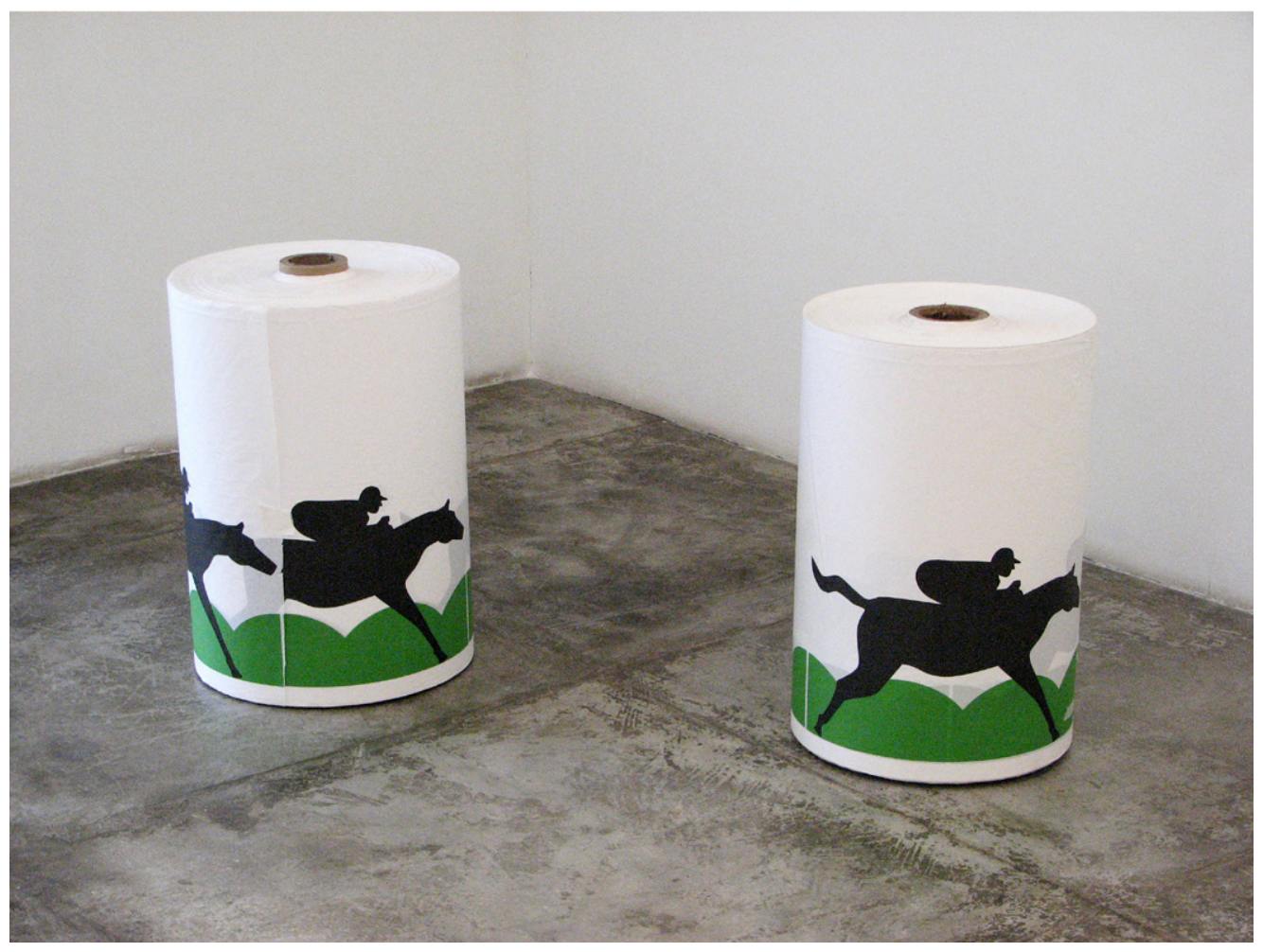

Não se sabe quando o gigante esteve na sala. Se num momento anterior, no passado remoto ou num presente paralelo, que o visitante aciona quando vai e vem, atravessando os andares, dentro do elevador. Tampouco se sabe quando fez, no elevador, seu autorretrato. O visitante recebeu o convite antes de ir ao museu, ou encontrou-o lá, empilhado sobre uma mesa no hall de entrada da sala, assim que saiu do elevador - antes de, movendo a cabeça em cinco posições, imitar a câmera de vídeo que, sabe-se lá quando, gravou o vai e vem, percorrendo o espaço, do gigante.

Fato é que, convite em mãos ou não, o visitante entrará na sala e, seja pela sugestão dada a ele no elevador, seja pela natureza dos trabalhos ali expostos, caminhará junto às paredes, evitando o centro do espaço. Feita a visita, voltará ao elevador, onde o gigante recomeça a contornar o perímetro. 


\section{NUMERADOR E DENOMINADOR}

- "1, 2, 3":

1. Uma vitrine de loja, embutida na parede e posicionada à altura do peito, horizontal, de 40 centímetros de altura por x centímetros de largura e x centímetros de profundidade, é revestida, na base, no fundo e no teto, por chapas comuns de eucatex perfurado, encontradas no mercado. Essas chapas têm furos com diâmetro de $\mathrm{x}$ milímetros, dispostos regularmente a cada $\mathrm{x}$ milímetros. $\mathrm{Na}$ frente e à direita, a vitrine é fechada por vidros. À esquerda, abre-se para o interior de outra vitrine, maior. Pintada de branco, a vitrine 1 é iluminada por uma lâmpada fluorescente de x centímetros de comprimento por $\mathrm{x}$ centímetros de diâmetro. Não há nada dentro dela, mas o formato é compatível com a exibição de joias ou relógios.

2. Uma vitrine de loja, embutida na parede e posicionada à altura da cintura, vertical, de 110 centímetros de altura por 1,2 x centímetros de largura por 1,2 x centímetros de profundidade, é revestida, na base, no fundo, no teto e na parede direita, por chapas de eucatex perfuradas sob medida, especialmente para o trabalho. Essas chapas têm furos com diâmetro de 1,2 $\mathrm{x}$ milímetros, dispostos regularmente a cada 1,2 x milímetros. Na frente, a vitrine é fechada por vidro. À esquerda, abre-se para o interior de outra vitrine, maior. Pintada de branco, a vitrine 2 é iluminada por uma lâmpada fluorescente de 1,2 x centímetros de comprimento por 1,2 x centímetros de diâmetro. Não há nada dentro dela, mas o formato é compatível com a exibição de calçados ou objetos de decoração.

3. Uma vitrine de loja, embutida na parede e posicionada à altura dos joelhos, vertical, de 190 centímetros de altura por 1,44 x centímetros de largura por 1,44 x centímetros de profundidade, é revestida, na base, no fundo, 
no teto e na parede direita, por chapas de eucatex perfuradas sob medida, especialmente para o trabalho. Essas chapas têm furos com diâmetro de 1,44 x milímetros, dispostos regularmente a cada 1,44 x milímetros. Na frente, a vitrine é fechada por vidro. À esquerda, abre-se para o interior de outra vitrine, maior. Pintada de branco, a vitrine 3 é iluminada por uma lâmpada fluorescente de 1,44 x centímetros de comprimento por 1,44 x centímetros de diâmetro. Não há nada dentro dela, mas o formato é compatível com a exibição de roupas, em manequins.

A vitrine 1 se encaixa num recorte na parede direita da vitrine 2, que, por sua vez, encaixa-se num recorte na parede direita da vitrine 3 . O mesmo ar, portanto, circula nas três vitrines. Elas derivam umas das outras, em progressão.

A face direita da vitrine 1 , revestida por vidro, dá para a rua. A face esquerda da vitrine 3, aberta, dá para o interior da grande vitrine que organiza a "Vistosa", exposição feita em parceria com os artistas Laura Huzak Andreato e João Loureiro, num pequeno galpão no bairro da Barra Funda, em São Paulo. "1, 2, 3” faz a mediação entre o que há à direita da vitrine 1 e o que há à esquerda da vitrine 3

A regra abstrata posta pelo título se aplica rigorosamente às larguras e profundidades das três vitrines (à sua planta-baixa), mas não às alturas. As medidas das alturas variam segundo outra regra, concreta: sugestão de uso para adereços, para calçados, para roupas.

Os furos nas chapas de eucatex, aumentando proporcionalmente segundo a regra abstrata, desnaturalizam a regra concreta: o revestimento familiar das paredes de lojas se altera, sutilmente. O transeunte, provável consumidor, possível visitante, se aproxima, mais, e mais.

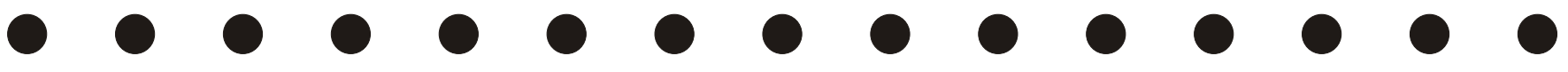

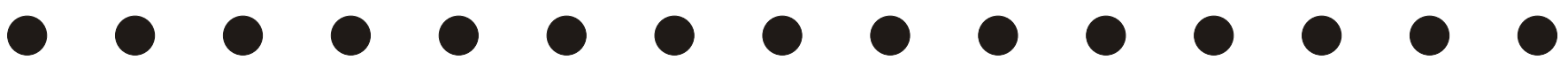

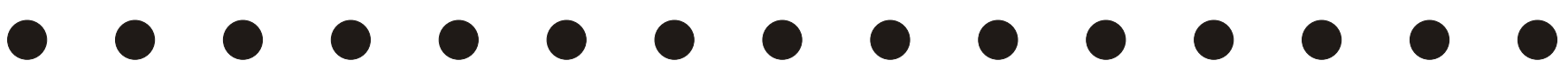

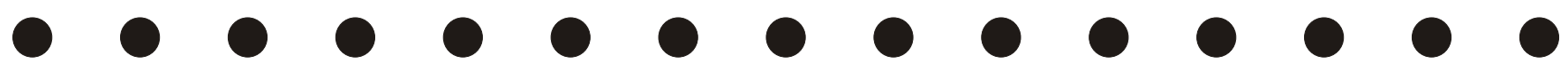

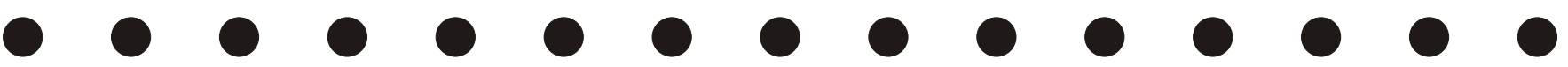

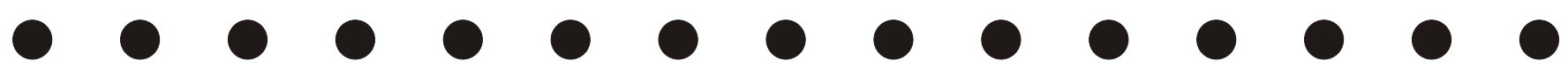

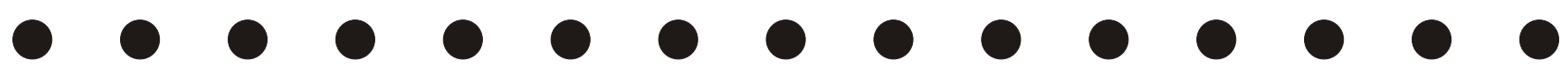

$\begin{array}{lllllllllllllll} & 0 & 0 & 0 & 0 & 0 & 0 & 0 & 0 & 0 & 0 & 0 & 0 & 0 & 0\end{array}$

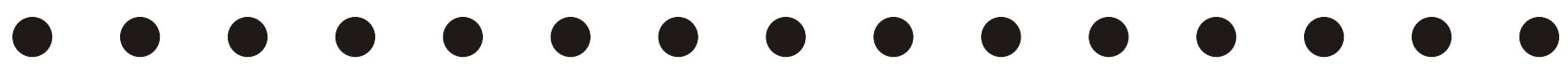

$\begin{array}{lllllllllllllll}- & 0 & 0 & 0 & 0 & 0 & 0 & 0 & 0 & 0 & 0 & 0 & 0 & 0 & 0\end{array}$

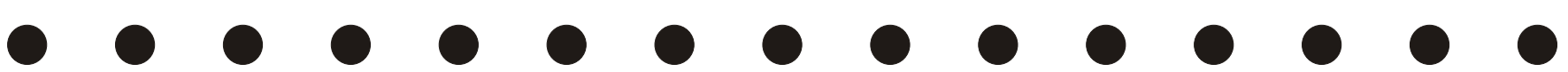

$\begin{array}{llllllllllllllll}- & 0 & 0 & 0 & 0 & 0 & 0 & 0 & 0 & 0 & 0 & 0 & 0 & 0 & 0\end{array}$

$\begin{array}{lllllllllllllll} & 0 & 0 & 0 & 0 & 0 & 0 & 0 & 0 & 0 & 0 & 0 & 0 & 0 & 0\end{array}$

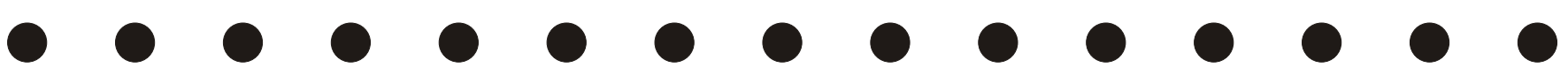

$\begin{array}{lllllllllllllll}- & 0 & 0 & 0 & 0 & 0 & 0 & 0 & 0 & 0 & 0 & 0 & 0 & 0 & 0\end{array}$

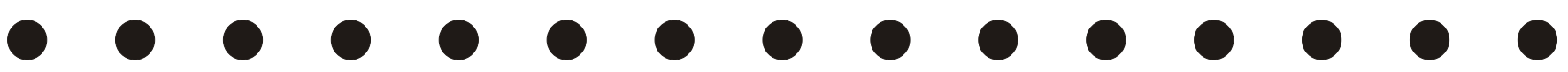

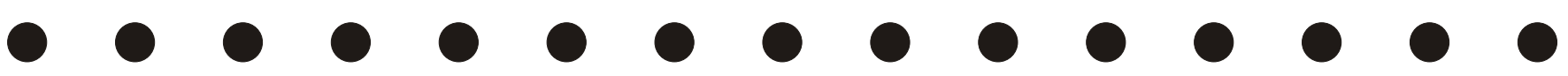

$\begin{array}{lllllllllllllll} & 0 & 0 & 0 & 0 & 0 & 0 & 0 & 0 & 0 & 0 & 0 & 0 & 0 & 0\end{array}$

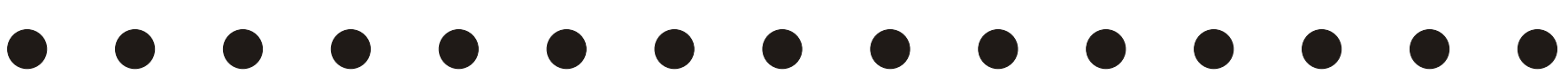




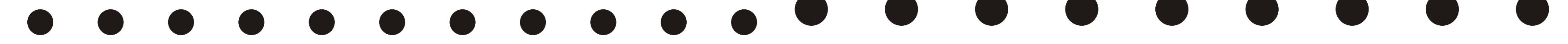

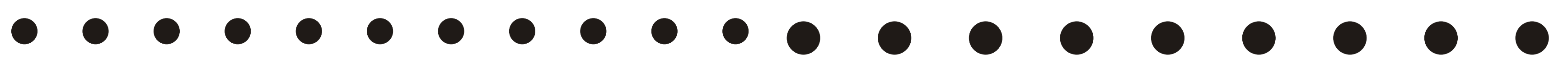

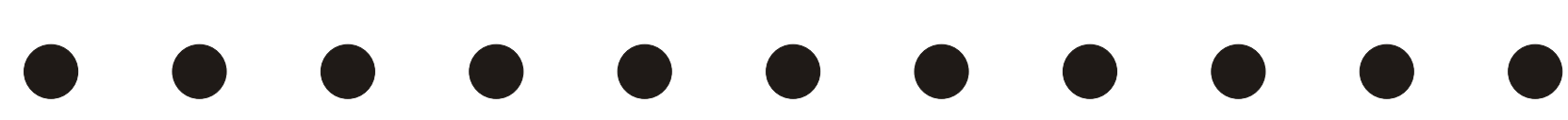

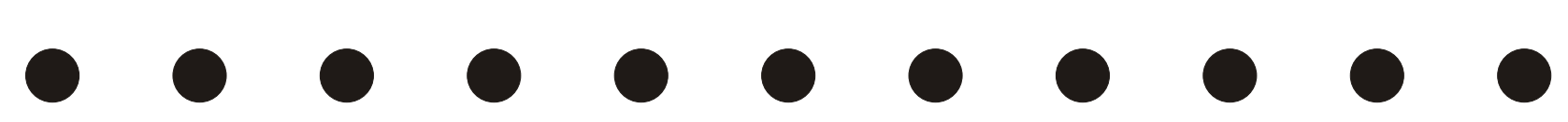
$\bullet \bullet \bullet \bullet \bullet \bullet \bullet \bullet \bullet \bullet \bullet$ - $\bullet \bullet \bullet \bullet \bullet-\bullet \quad \bullet$ $\bullet \bullet \bullet \bullet \bullet \bullet \bullet \bullet \bullet$ $\bullet \bullet \bullet \bullet \bullet \bullet \bullet \bullet \bullet \bullet \bullet$ $\bullet \bullet \bullet \bullet \bullet \bullet \bullet \bullet \bullet \bullet \bullet \bullet$

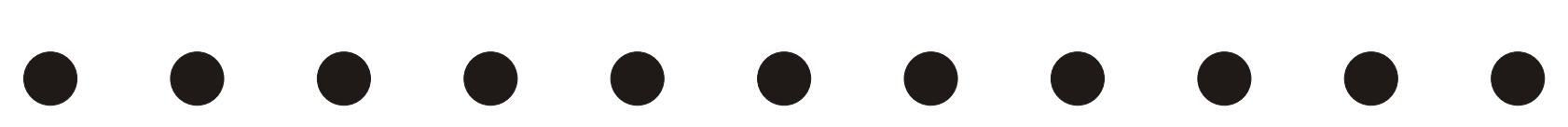

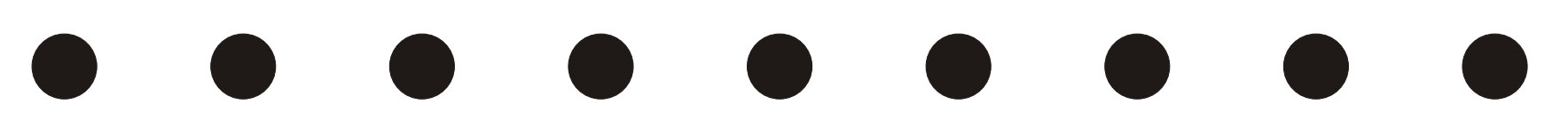

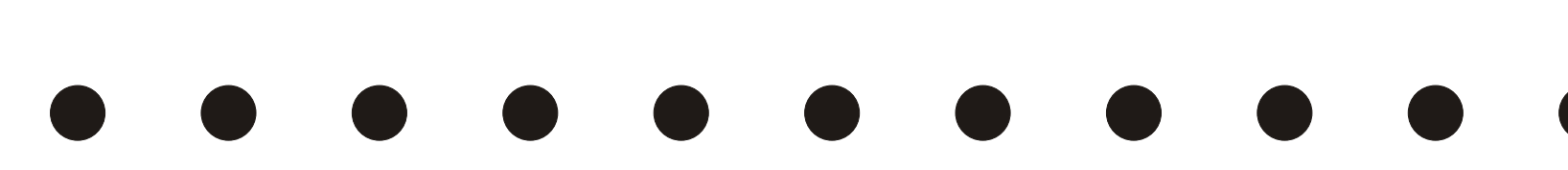
$\bullet \bullet \bullet \bullet \bullet \bullet \bullet \bullet \bullet \bullet$ $\bullet \bullet \bullet \bullet \bullet \bullet \bullet \bullet \bullet \bullet \bullet$ $\bullet \bullet \bullet \bullet \bullet \bullet \bullet \bullet \bullet \bullet \bullet$ $\bullet \bullet \bullet \bullet \bullet \bullet \bullet \bullet \bullet \bullet \bullet$

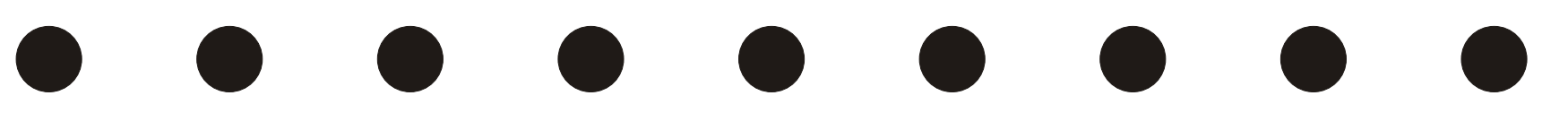

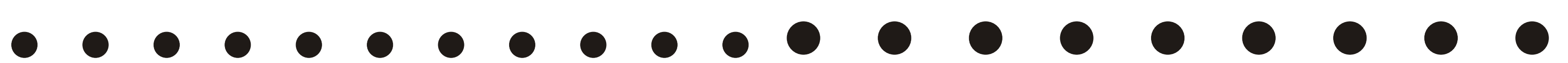
$\bullet \bullet \bullet \bullet \bullet \bullet \bullet \bullet \bullet \bullet \bullet \bullet \bullet ⿺ 辶 ⿻$ 


\section{- "Rodagem":}

Numa sala pequena, comprida e estreita que sai do hall de entrada, vê-se um céu pintado, do formato do teto, mas deslocado em relação a ele. Nuvens brancas sobre fundo azul, efeitos esfumaçados com esponjas e pincéis, executados livremente (segundo as convenções do métier) por profissionais especializados em pintura decorativa. Um terço do retângulo pintado cobre o forro e os outros dois terços escorregam pela parede esquerda. $\mathrm{Na}$ diagonal oposta, um carro de controle remoto, um jipe preto de escala 1:10, liga-se por um fio à corrente elétrica. Ele é programado para funcionar em intervalos regulares, a cada cinco segundos, durante cinco segundos. Em funcionamento, no chão, para-choque encostado à parede direita, o carrinho move as rodas em sentido horário, tentando avançar. Atravessar a parede ou escalá-la. Ele não sai do lugar.

Numa salinha ínfima, comprida e estreita que sai da sala pequena, comprida e estreita, vê-se um céu pintado, do formato do teto, mas deslocado em relação a ele. Nuvens brancas sobre fundo azul, efeitos esfumaçados com esponjas e pincéis, executados precisamente (reproduzindo a pintura da sala anterior) por profissionais especializados em pintura decorativa. Um terço do retângulo pintado cobre o forro e os outros dois terços escorregam pela parede esquerda. Na diagonal oposta, um carro de controle remoto, um jipe preto de escala 1:20, liga-se por um fio à corrente elétrica. Ele é programado para funcionar em intervalos regulares, a cada cinco segundos, durante cinco segundos. Em funcionamento, no chão, para-choque encostado à parede direita, o carrinho move as rodas em sentido horário, tentando avançar. Atravessar a parede ou escalá-la. Ele não sai do lugar.

Os dois carros de controle remoto, em escalas 1:10 e 1:20, têm exatamente o mesmo desenho, são feitos dos mesmos materiais, têm a mesma cor, funcionam e desligam-se simultaneamente e estão em posição análoga, centralizados em relação às paredes direitas das duas salas.

Os dois céus pintados, um com a metade da área do outro, têm exatamente as mesmas cores, a mesma composição, os mesmos gestos, os mesmos efeitos. Cada um deles ocupa um terço dos tetos de suas salas e uma fração da parede esquerda, equivalente à área em branco nos tetos. Nessa parede, que se estende pelos dois ambientes, os céus se encostam.

A proporção entre largura e profundidade da salinha ínfima é igual à da sala pequena, mas sua área é menor: a metade. Os pés-direitos, originalmente iguais, foram modificados. Rebaixou-se o pé-direito da salinha, se não para alcançar a proporção da sala pequena, para alinhar-se à viga que atravessava a passagem, interrompendo a derivação dos espaços, o encontro dos dois céus e a fluidez do movimento virtual indicado no título.

Aliás, se não fosse "Rodagem" (a regra ficcional), o título do trabalho seria “1:1". 1:1, e não $1: 2$, porque os dois carros não são representações em escala de carros reais, mas carrinhos de controle remoto, e, nas representações do céu, não se podendo aferir o tamanho do objeto real, não há escala.

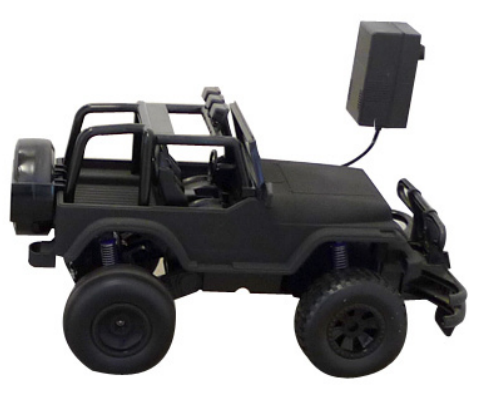

NUMERADOR E DENOMINADOR | 37 


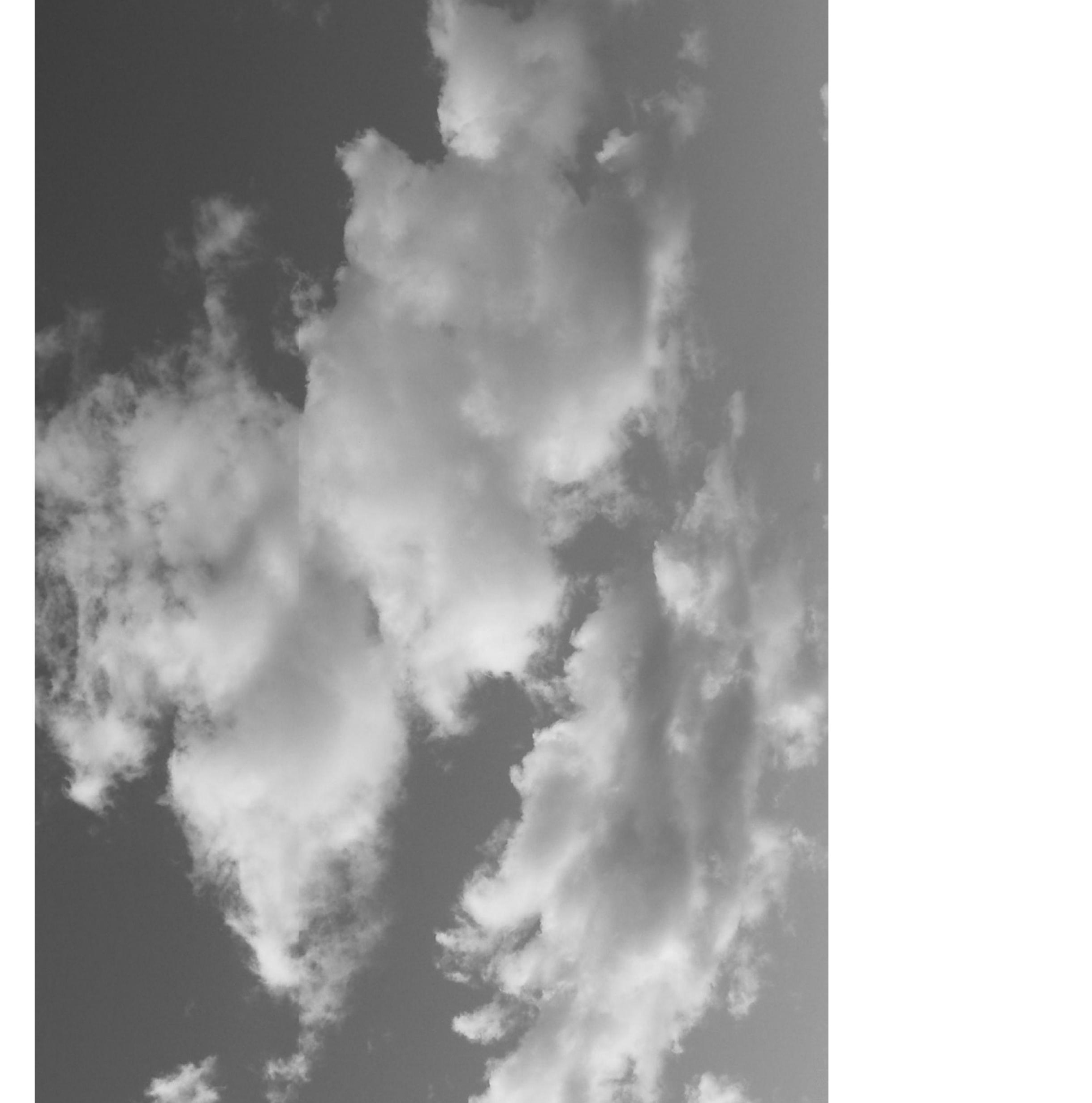


- "PARADA":

Uma placa fina de foam board branco, com $5 \mathrm{~mm}$ de espessura, acondicionada em uma caixa justa de acrílico transparente. No centro há um recorte, feito a laser, com os contornos de uma figura humana diminuta, em escala 1:50. A figura subtraída representa um homem de negócios com uma pasta, visto de frente, com uma perna projetada, como se caminhasse em direção ao observador. A placa tem $180 \mathrm{~cm}$ de altura. Sua largura é obtida dividindo-se a altura por três: $1: 3$.

Outras duas placas de foam board branco, igualmente finas, acondicionadas em caixas igualmente justas de acrílico transparente. Nos centros os recortes, feitos a laser, com os contornos da figura humana em escala 1:50 que representa um homem de negócios com uma pasta, visto de frente, uma perna projetada, como se caminhasse em direção ao observador. As placas têm, respectivamente, 72 e 36 cm de altura. Suas larguras são obtidas dividindo-se as alturas por três: $1: 3$

A proporção entre altura e largura é igual nas três placas: a mesma da figura humana recortada. Em todas as placas, a figura é do mesmo tamanho. A placa maior tem a altura de um homem adulto. Suas dimensões são obtidas multiplicando-se por 50 as da figura recortada: 50:1. A segunda placa é muito menor. Suas dimensões são obtidas multiplicando-se por 20 as da figura recortada: 20:1. A terceira placa tem 10 vezes as dimensões da figura. As placas são o suporte físico da figura negativa e o elemento real com o qual ela se mede, calibrando sua escala.

As três placas são acondicionadas em caixas de acrílico e posicionadas na parede lado a lado, ordenadas da maior para a menor, com intervalos regulares. A caixa maior apoia-se no chão. As demais são penduradas, alinhando-se as figuras negativas. O acrílico, extraído do mesmo repertório das chapas de foam board e das representações em escala de homens de negócios, isola recorte e placa, figura e suporte, em suas comparações de grandeza.
A sucessão das placas sugere uma operação de escala às avessas em que as dimensões variáveis não são as do objeto representado, mas as da própria realidade, as do suporte. Quando o real se contrai, a representação,

inversamente, parece se expandir. Em "Parada", a figura, aquele espectro de um homem de negócios congelado à beira do próximo passo, avança. 
- "Pulga":

Uma lupa conta-fios dentro de uma lupa conta-fios dentro de uma lupa contafios. A lupa média é x vezes menor que a grande e a pequena é $\mathrm{x}$ vezes menor que a média. A capacidade de ampliação das três lentes é igual: 10 vezes. Ainda que a área enquadrada na base da lupa pequena seja ampliada 1000 vezes, não se pode enxergar o chiste do título, pois ela fica fora de foco.

Uma pulga é capaz de pular 200 vezes o próprio tamanho.
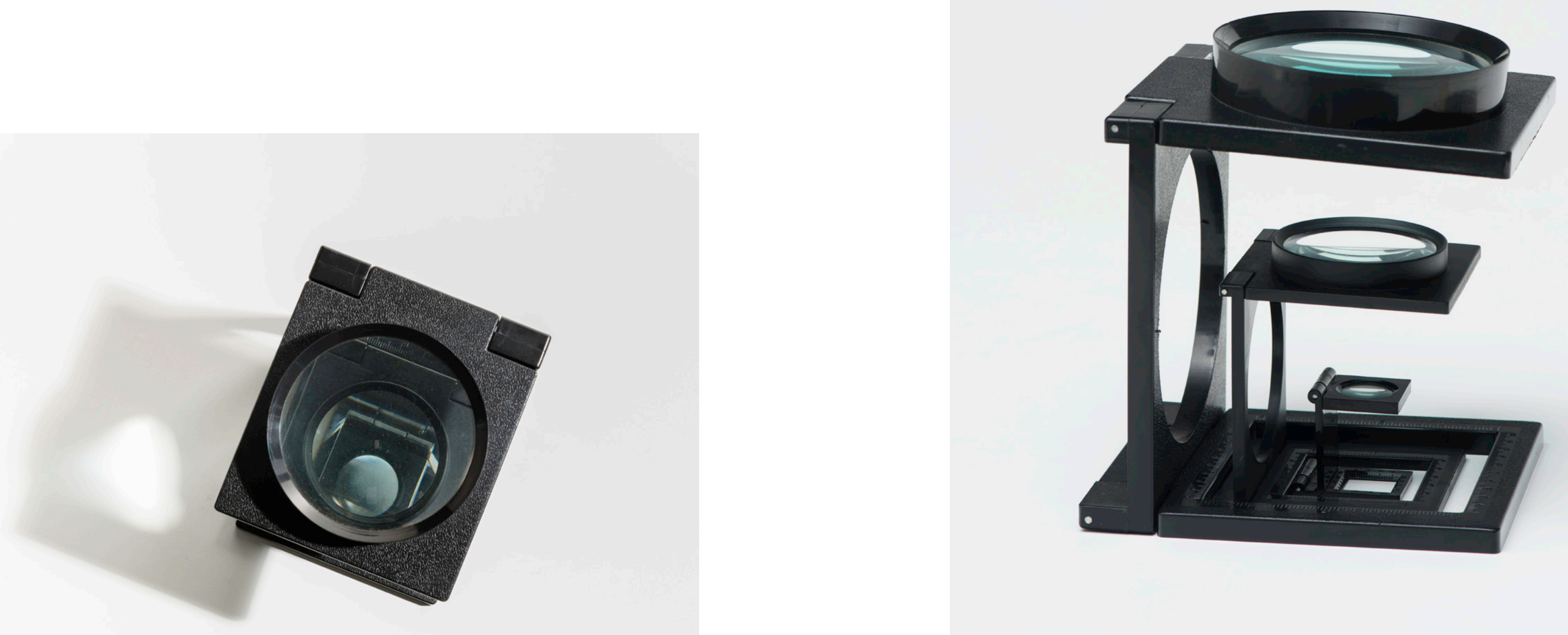
O DIA DO JABUTI
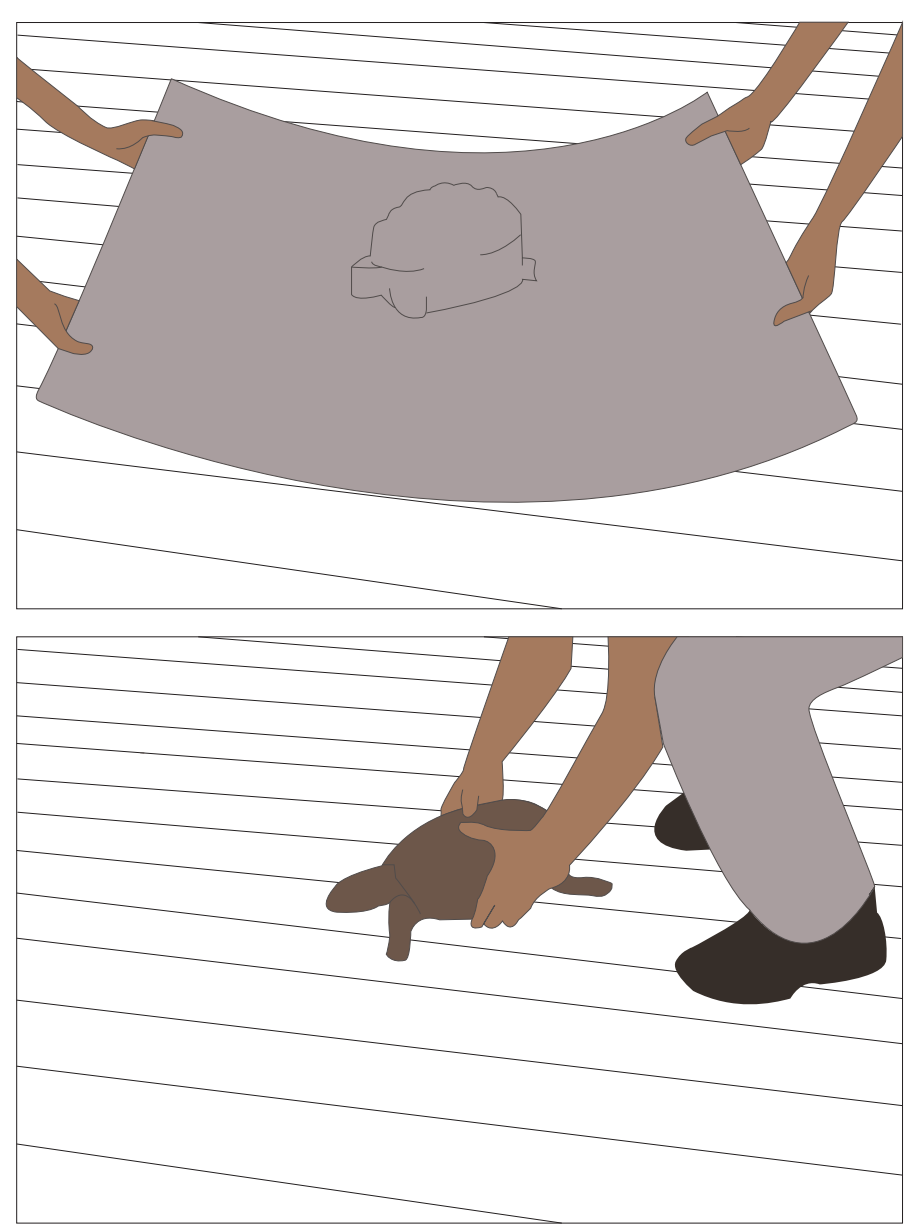

No dia 12 de dezembro de 2009, um jabuti do Zoológico de Taboão da Serra foi transportado para a Estação Pinacoteca, em São Paulo. No terceiro andar do museu, foi solto no local exato ocupado até então, na minha exposição individual, por uma placa quadrada de plástico transparente semiflexível, moldada a vácuo.

A placa de plástico PETG transparente, de 120 por $120 \mathrm{~cm}$, com 1,5 mm de espessura, tinha sido moldada pelo processo de vacuum forming, seguindo técnica de confecção das embalagens blister. Nessas embalagens, o plástico semiflexível forma uma bolha que reproduz, simplificada, a silhueta do produto a ser contido. O molde para a placa quadrada havia sido esculpido em alumínio por uma máquina $\mathrm{CNC}$, a partir de um projeto em 3D, baseado, por sua vez, no escaneamento tridimensional de um animal vivo, um jabuti.

Posicionado onde esteve a placa quadrada de PETG transparente, o jabuti do Zoológico de Taboão da Serra pôs a cabeça e as patas para fora do casco, olhou ao redor, deu dois ou três passos, parou por minutos, avançou em diagonal, parou, andou. Ele se deslocava com menor frequência e maior velocidade do que nas fábulas que protagoniza. 
Visitantes do museu entraram na sala, olharam ao redor, viram o jabuti, seguiram adiante. Sua presença era mais familiar e menos ruidosa do que sugerem relatos de trabalhos com animais vivos em exposições de arte.

No meio da tarde, o jabuti se desinteressou das curvas, das diagonais e dos deslocamentos em profundidade. Adotou uma rota: foi e voltou junto ao painel do fundo, revestido por um papel de parede.

O papel de parede, de 2,80 por 56 metros, com uma textura levemente rugosa, havia sido impresso em empresa especializada, a partir de um arquivo digital. $\mathrm{O}$ arquivo fora montado com a sobreposição de imagens dos seguintes elementos, fotografados individualmente: o fragmento de um papel de parede listrado, em branco e cinza; uma tomada embutida, com espelho; três pinturas com o motivo incêndio florestal; três molduras brancas; um rodapé de madeira pintado de branco.

Junto ao rodapé reproduzido no papel de parede aplicado no painel do fundo, o jabuti continuava. Seu comportamento era menos livre e mais livre do que sugerem nossas representações. Não tão livre, entretanto, para se desemparelhar das coisas domésticas.

As três pinturas de incêndio florestal haviam sido realizadas, sob encomenda, por um pintor. Na primeira via-se uma floresta em cinzas recentes. Na segunda, a floresta em chamas, labaredas e fumaça escura. Na terceira, a floresta verde e fumaça se aproximando a partir do canto esquerdo. A mesma floresta nas três pinturas, não se sabe se vista em três momentos, ou se vista ao mesmo tempo, em três recortes, que, posicionados como na montagem digital que originou o papel de parede, constituiriam trechos de uma única vista panorâmica.
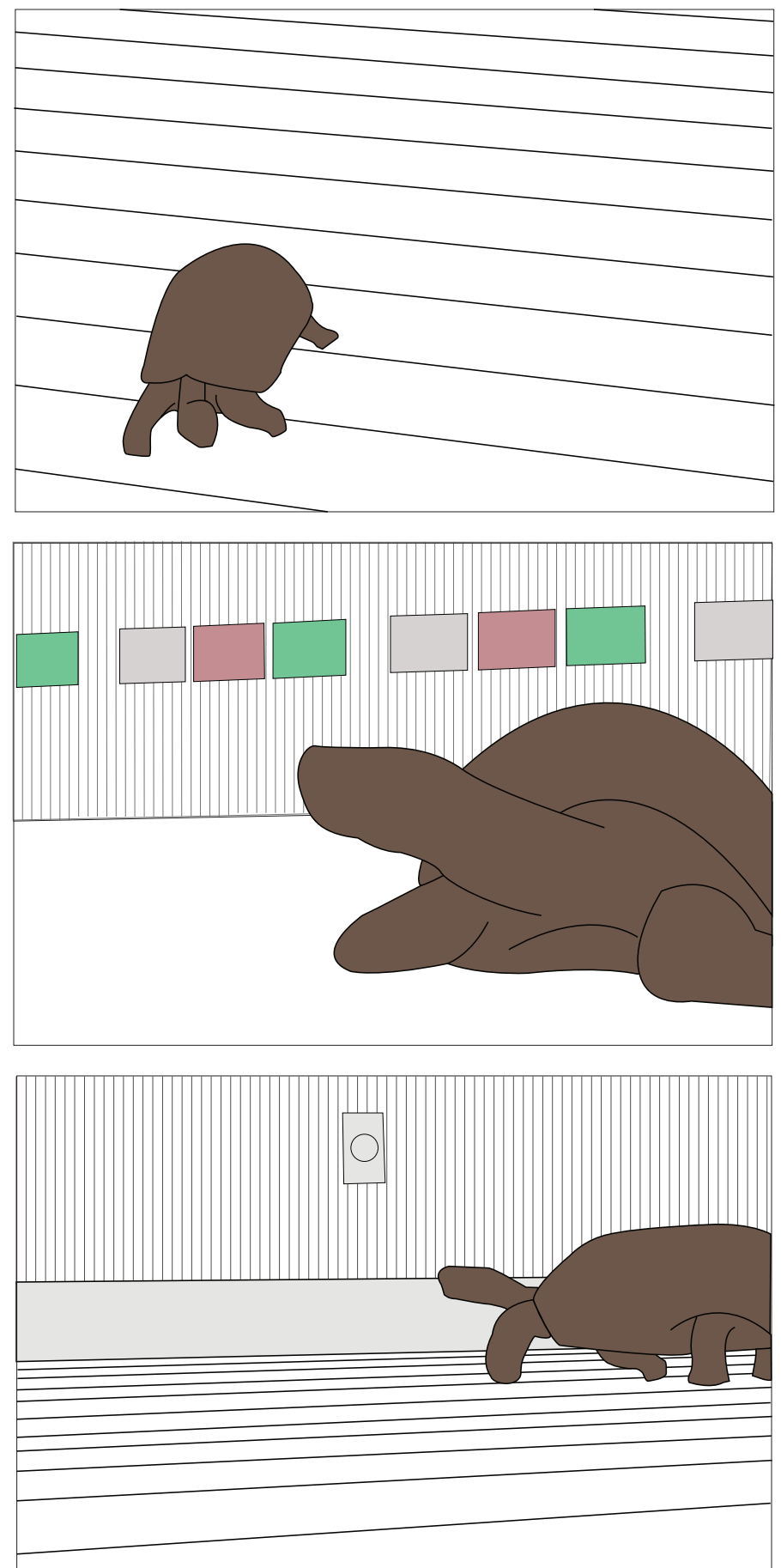

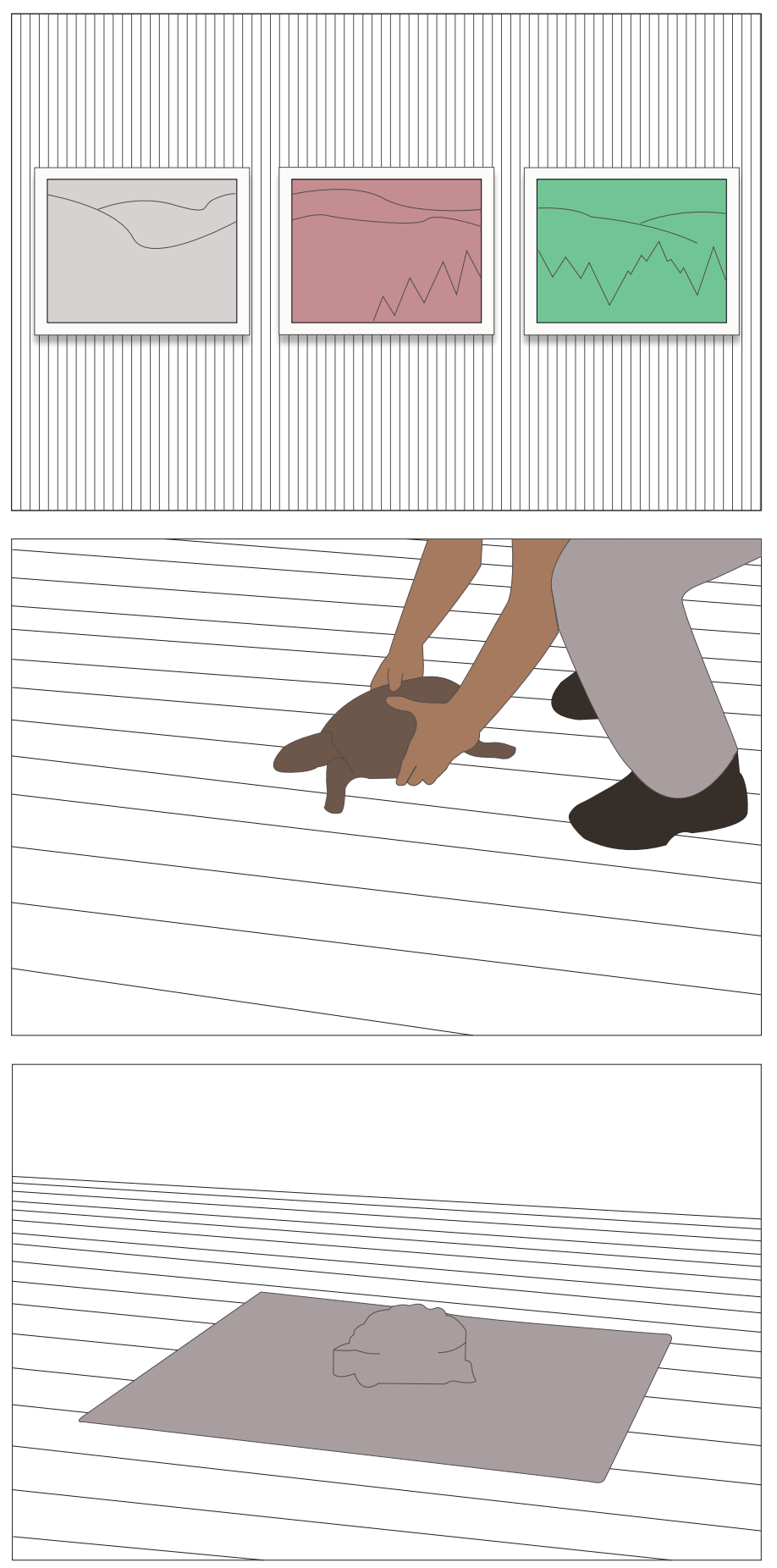

O papel de parede reproduzindo a vista de uma parede doméstica (com papel de parede listrado, rodapé, tomada e três pinturas de incêndio florestal, emolduradas), em módulos de 2,5 metros de largura, repetia-se ao longo de 56 metros, dobrando-se nas quinas das duas faces laterais que ligavam o painel do fundo ao fundo da sala.

Quando o jabuti ia da esquerda para a direita diante do painel, no sentido do vento, que orienta o progresso do incêndio, representado nas três pinturas, reproduzidas no papel de parede, a sucessão das pinturas sugeria continuidade espacial. Quando o jabuti vinha da direita para a esquerda, as três pinturas se sucediam em ordem cronológica: um pouco antes, durante e logo depois da passagem do fogo. No primeiro caso, o tempo da floresta parava e corria o tempo do deslocamento do jabuti. No segundo, parava o tempo do deslocamento do jabuti, correndo o da floresta em chamas. O jabuti não dobrou a quina, então algo do trabalho intitulado "Queimada”, neste texto, nos escapará.

Quando o museu fechou, às 19 horas, o jabuti foi recolhido e transportado de volta ao Zoológico de Taboão. Na manhã seguinte, a legenda que havia sido adicionada à exposição na véspera, na qual se lia “O jabuti, 2009”, foi substituída por outra, em que se leu "Casco, 2009”, como, de resto, se lera na antevéspera e nos dias anteriores.

A placa quadrada de plástico foi recolocada na posição original, paralela às linhas do piso e às paredes. A bolha no centro da placa, deslocada em relação aos eixos do quadrado, tinha a forma de um jabuti em movimento, patas alternadas, cabeça projetada, em escala real. A forma de um jabuti avançando em diagonal, pata dianteira flexionada, largada a de trás, lento agora, e não tão avesso aos atributos de sabedoria e constância que lhe conferem as fábulas, ou à expectativa de estranhamento e ruído gerada pela transposição de contexto. Não tão avesso às nossas representações. 


\section{O CENTRO}

O papel margeado para desenho técnico tem duas margens, uma dentro da outra. A margem externa replica os limites do papel, mantendo deles uma distância constante em todas as extremidades. A margem interna delimita um retângulo mais estreito, correspondente ao formato A4. No topo e nas laterais, ela conserva uma mesma distância da margem externa. Na base, essa distância se multiplica. A linha que define a margem externa é mais fina do que a linha que define a margem interna. Uma única linha vertical da espessura da margem externa atravessa a distância entre as duas margens na base, indicando o centro horizontal do papel.

O espaço maior entre margens na base é reservado para dados que dizem respeito à interpretação do desenho a ser feito no campo central. Esse desenho será uma representação bidimensional, geralmente reduzida, de um espaço ou objeto concreto, existente ou a ser construído. Entre as margens serão anotados a identificação do espaço ou objeto representado, o local em que está ou será construído, autores do desenho ou do projeto e a escala utilizada na representação. Esses dados não pertencem à realidade virtual do desenho, tampouco à realidade propriamente dita, extrapapel, concernem à transposição entre as duas realidades e seu estatuto corresponde à posição que ocupam.

O campo central é, portanto, dissociado do espaço real por meio de três recortes sucessivos: os limites do papel, a margem externa e a margem interna. A variação de espessura das margens permite que se ordenem os 
espaços de modo que a progressão rumo à virtualidade absoluta do campo central, implacável, se dê suavemente. Resulta um campo rigorosamente esquadrinhado para receber as projeções que detêm, nas folhas margeadas, o título de desenhos.

Nas impressões offset coloridas, a arte final a ser impressa é dividida, por padrão, em quatro cores primárias cuja sobreposição permite reproduzir a maioria das cores do espectro visível. Esse sistema é conhecido como quadricromia. As cores são ciano, magenta, amarelo e preto. Para transferir cada uma dessas cores, produz-se uma chapa de offset em que as áreas preenchidas são transformadas em malhas de pontos. A tinta para offset é semitransparente, de modo que, com a impressão sucessiva das chapas, as retículas das quatro cores se sobrepõem no papel, formando as combinações de matizes e tons necessárias à reprodução da imagem original.

Para que essa reprodução se dê com fidelidade, entretanto, é fundamental que o volume de tinta transferido pelas quatro chapas seja uniforme e que as retículas das quatro cores se encaixem perfeitamente. Um conjunto de elementos acrescentados à chapa e impressos no papel no entorno dos limites da arte final auxilia no controle do processo. A quantidade de tinta é calibrada pela equiparação da variação tonal de cada cor numa escala de tons. Já o encaixe das retículas é controlado ajustando-se a sobreposição das marcas de registro, geralmente círculos atravessados no centro por uma cruz de espessura mínima. À escala de tons e às marcas de registro somam-se as marcas de corte, que orientam o refile do papel. Quando o papel é refilado, a peça gráfica acabada é separada desses elementos marginais, cujo estatuto corresponde à posição que ocupam.

Num modelo padrão de diagramação de páginas de texto em formato A4, o espaço do papel é dividido em três campos: cabeçalho, corpo e rodapé.

O corpo situa-se na área central da página e recebe o texto propriamente dito, organizado em parágrafos. O cabeçalho e o rodapé, duas faixas situadas respectivamente no topo e na base da página, contêm informações de inserção opcional e caráter geral, que se repetem ao longo do documento, tais como: o número total de páginas e a numeração da página atual; o título do livro, coletânea ou revista e o título do artigo, capítulo ou seção atuais; os autores do livro, coletânea ou revista e os autores do artigo, capítulo ou seção atuais. No rodapé, além disso, inserem-se notas explicativas vinculadas a passagens do corpo do texto, identificadas com números sobrescritos.

A formatação varia nos três campos. No corpo usa-se fonte regular de tamanho médio e os parágrafos são alinhados à esquerda ou justificados, com espaço múltiplo entre as linhas. No cabeçalho e no rodapé usam-se espaço entrelinhas simples e a mesma fonte do corpo em tamanho reduzido, às vezes em caixa-alta. As informações são dispostas lado a lado, cada uma delas centralizada ou alinhada a uma das extremidades da mancha. Quando há, no rodapé, notas explicativas, usam-se também entrelinhas simples e fonte regular de tamanho reduzido, justificando-se o texto ou alinhando-o à margem esquerda.

Regula-se a legibilidade dos elementos textuais de acordo com a sua relevância, que diminui do centro para as bordas. As informações no cabeçalho e no rodapé, intermediárias, ou remetem o conteúdo do texto ao contexto mais amplo da publicação em que inscreve ou, no caso das notas, vinculam pontos isolados desse conteúdo a desdobramentos autônomos, que não produzem consequências no fluxo geral. O estatuto dos elementos textuais corresponde à posição que ocupam. 
Partindo de uma folha margeada convencional, subtraí ou acrescentei linhas e tracei oito modelos de margens, com os quais foram produzidos oito modelos de blocos para desenho técnico. O trabalho foi intitulado "Blocos margeados". Cada bloco tem 100 folhas idênticas unidas com cola vermelha e uma capa que reproduz, na base, o arranjo de linhas das folhas internas reduzido à metade do tamanho original. Tal como nos blocos de desenho técnico convencionais as capas são de cartolina colorida em tons pastéis, adotando-se uma cor para cada modelo.

Em dois dos modelos, os blocos de capas amarela e bege, linhas adicionais da espessura da margem interna recortam o campo central, lembrando esquemas compositivos de bandeiras.

No bloco de capa marrom, uma linha vertical centralizada atravessa o campo a partir do topo. Ela não atinge a margem inferior e mantém comunicantes as duas áreas que conforma.

No bloco verde, o campo central também é dividido ao meio guardando-se passagens entre as áreas resultantes. Ali, em vez de uma única linha, há dois retângulos alongados cujas proporções remetem a paredes vistas em plantabaixa.

No bloco laranja, o espaço entre margens vaza para dentro do campo central, numa gota ortogonal.

No bloco rosa, a linha entre as margens que aponta o centro horizontal do campo é duplicada. Mais espesso, o duplo deslocado altera a percepção do centro.

No bloco azul duas linhas curtas, horizontais, indicam o centro vertical do espaço entre margens, como se também ele precisasse ser esquadrinhado.

No bloco salmão, finalmente, o canto inferior direito da margem externa é fatiado, intercalando-se os fragmentos de linhas verticais e horizontais numa escada ascendente.

As margens são desenhos, desenhos feitos para receber desenhos.
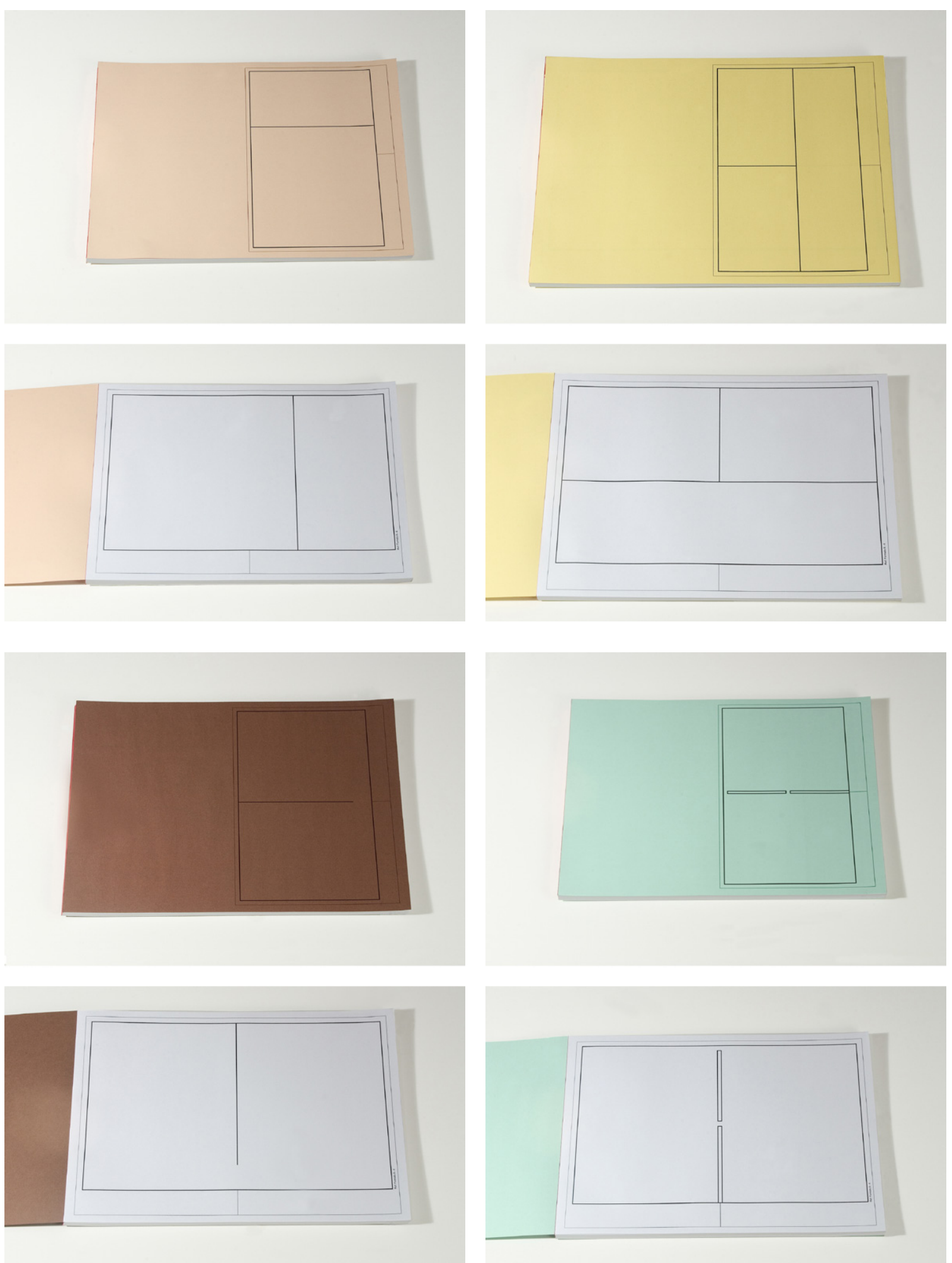

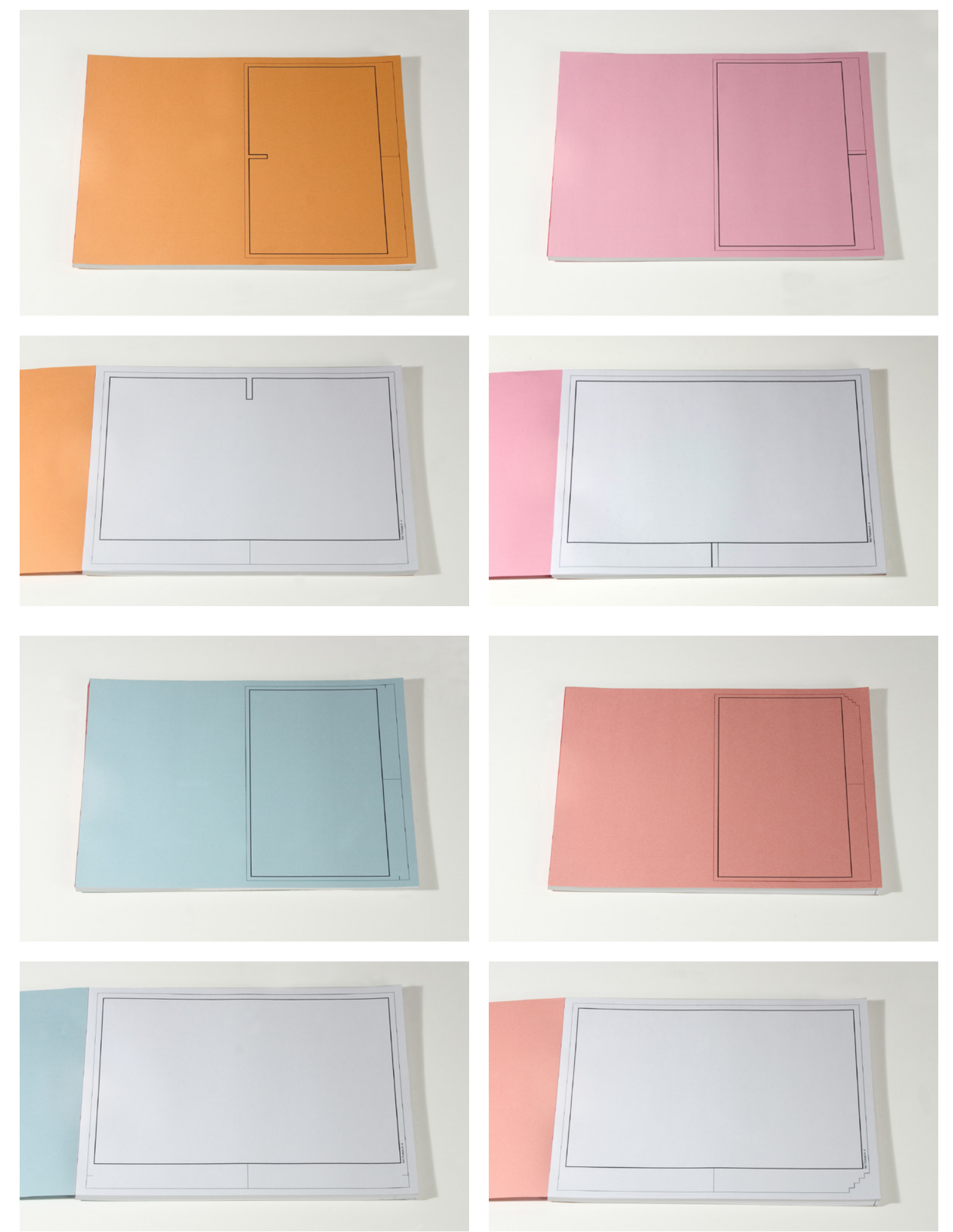

“Moiré" é uma serigrafia sobre papel realizada em quatro cores, as quatro cores primárias da impressão offset. Os mesmos elementos são reproduzidos em ciano, magenta, amarelo e preto. São eles: uma escala de tons, marcas de corte, marcas de registro e a identificação do arquivo que originou a arte final. A arte final é um campo em branco; os elementos acima enumerados foram acrescentados automaticamente pelo software, no momento em que se exportou o arquivo para impressão.

Embora o processo a que "Moiré" se refere seja a impressão offset, com suas cores e suas falhas padrão, o trabalho é uma serigrafia. Uma única tela gravada a partir de um único arquivo original foi utilizada para transferir as quatro cores. As cores foram transferidas na ordem da impressão offset: primeiro o ciano, depois o magenta, o amarelo e, finalmente, o preto.

No momento de se posicionar cada folha de papel sob a tela entintada com as diferentes cores, não se controlou o registro. Assim, as impressões em ciano, magenta, amarelo e azul, idênticas e sobrepostas, ficaram levemente deslocadas umas das outras, ao acaso. Nas linhas de corte, na identificação do arquivo, na escala de tons, nos quatro alvos que marcam o registro produziram-se interferências, imagens secundárias que os olhos tentam, sem sucesso, reunir. Foram feitas vinte cópias, cada uma delas diferente das demais, somando-se aos desvios arbitrários de registro uma linha interrompida, uma linha estourada, falhas próprias à serigrafia, discretamente incorporadas.

Não houve refile e, embora o campo destinado à arte final permaneça em branco, projetam-se nele, perturbando sua disponibilidade, retículas transparentes, desencontradas. 

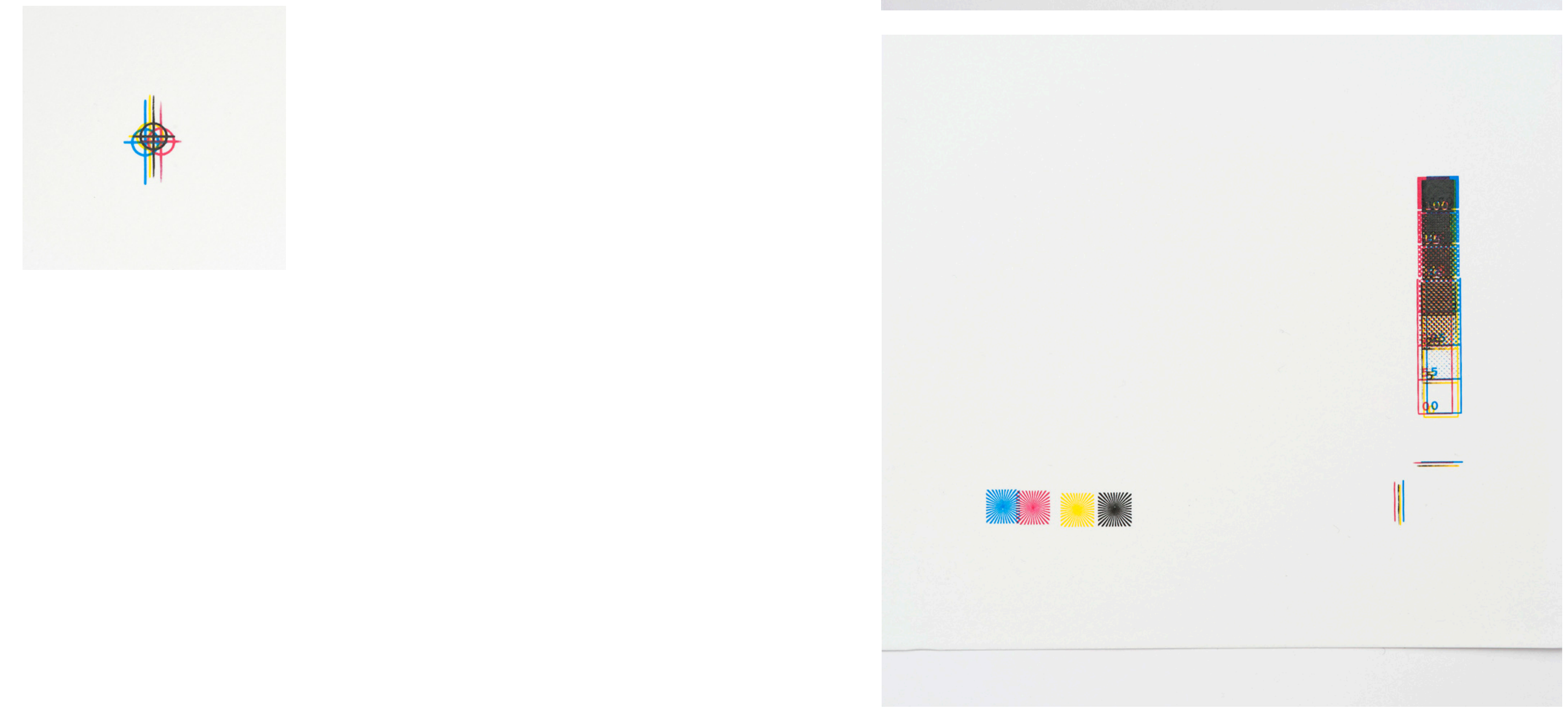
Em “Cambalhota”, um calígrafo profissional foi contratado para escrever três palavras em três folhas de papel de formato A4 dispostas em sequência. As três palavras são escritas com a mesma letra cursiva, comercial inglesa, do mesmo tamanho. Cada uma delas ocupa uma linha e as três linhas, muito próximas e alinhadas pelo centro horizontal, ocupam o centro vertical das folhas de papel.

As três palavras são cabeçalho, corpo e rodapé. Na primeira folha elas estão arranjadas, de cima para baixo, na ordem em que aparecem na frase anterior. Na segunda, corpo e cabeçalho trocam de posição e lê-se: corpo, cabeçalho, rodapé. Na terceira rodapé está em cima, corpo no meio e cabeçalho embaixo.

Escritas à mão, em letra cursiva, agrupadas no centro do papel, as três palavras tentam mobilizar, em três tempos, os campos que designam.
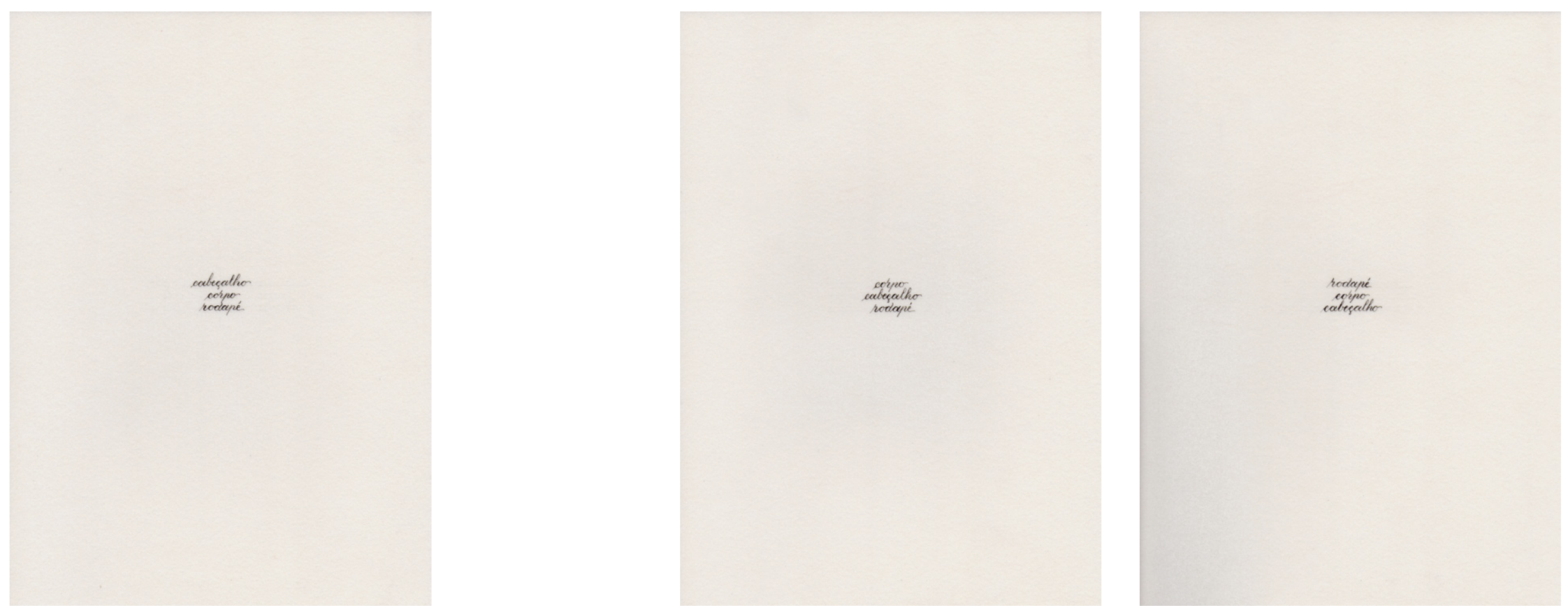
O QUE É, O QUE É? SEU NÚCLEO É CONSTITUÍDO DE

FERRO, NÍQUEL ETALVEZ ENXOFRE

Os dois trabalhos são feitos de madeira maciça entalhada. Em ambos conservam-se as marcas da goiva.

Nos dois trabalhos há representação, há referentes nomeáveis. Em ambos as marcas da goiva, índice, mas também signo do entalhe, são remetidas a características desses referentes.

Os dois trabalhos têm formas simples e superfícies contínuas. A única ocorrência são as marcas da goiva, índice e signo do próprio entalhe, mas também incorporação de características dos referentes, referentes que, entretanto, têm poucas características comuns.

Os dois títulos omitem, sugerem charada.

O que é, o que é? É uma caixa mas nenhum carpinteiro faz.

Nozes parecem de madeira. As peças de “O que é, o que é?” parecem nozes. “O que é, o que é?" é de madeira. As peças de “O que é, o que é?" têm a forma da noz, o tamanho da noz, o peso da noz, a cor da noz. São feitas do material de que seu referente parece ser feito. As peças de “O que é, o que é?" tentam se passar por seu referente, porque seu referente, que parece ser feito, se passaria por elas. 
Tenho olhos e não vejo, tenho boca e não falo, ando e não tenho pernas.

"Seu núcleo é constituído de ferro, níquel e talvez enxofre" é de madeira. Tem $40 \mathrm{~cm}$ de diâmetro, pesa uns 20 quilos, é marrom. Contraria as afinidades de seu referente, embora compartilhe com ele ocorrências de superfície. "Seu núcleo é constituído de ferro, níquel e talvez enxofre” não tenta se passar por seu referente, porque as características de seu referente, imaginadas à saturação, insistentemente representadas, são intangíveis.

Se as vacas voassem para onde elas iriam?

As peças de "O que é, o que é?" são dispostas sobre superfície neutra, base branca. "Seu núcleo é constituído de ferro, níquel e talvez enxofre" assenta no piso, um piso de madeira, como ele mesmo. As peças de "O que é, o que é?" flutuam no vácuo, separadas do mundo que seu referente habita. "Seu núcleo é constituído de ferro, níquel e talvez enxofre" pesa no chão, continua o mundo, um mundo, entretanto, alheio ao seu referente.

O que é, o que é? Seu núcleo é constituído de ferro, níquel e talvez enxofre.

Adivinhações baseiam-se em jogos de palavras, sentidos figurados.

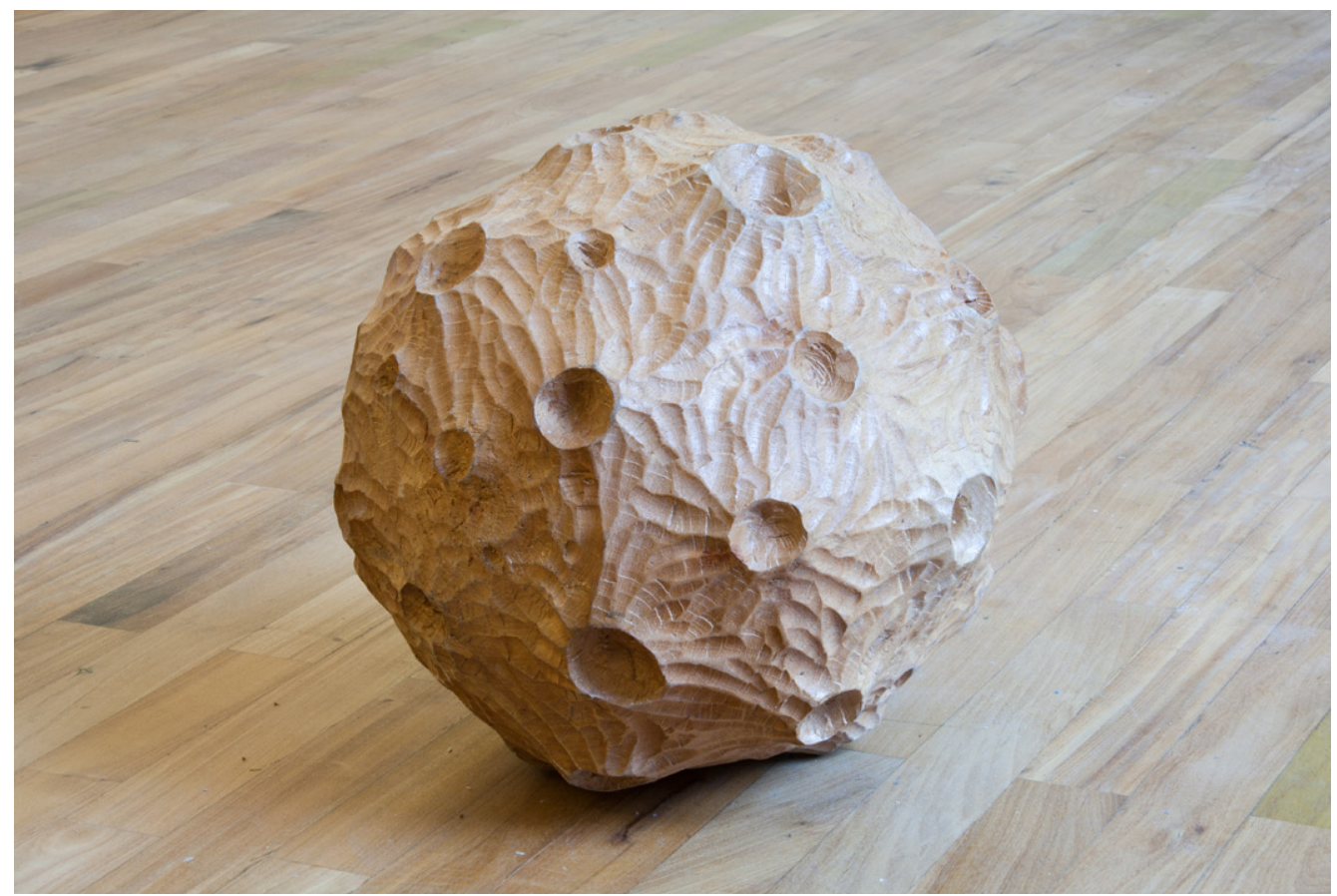




\section{RUÍDO BRANCO}

"Crocante" é um trabalho de 2009, feito para a exposição "Programa", na Estação Pinacoteca. A exposição aconteceu no $3 .^{\circ}$ andar do prédio, um piso intermediário, espécie de mezanino que atravessa o pé direito original, interrompendo à meia altura os janelões da fachada. A sala sempre esteve revestida de painéis e, dobrando-se ao teto baixo, costumava abrigar exposições de trabalhos de pequeno formato. Em "Programa", foram removidos os painéis, revelando-se os topos em arco das janelas e também um estreito vão no piso pelo qual se enxerga a continuidade delas no andar de baixo. A luz natural e os dados do entorno do museu passaram a preencher a sala, obrigando os trabalhos da exposição a uma espessura mínima.

Os trabalhos da exposição tinham espessura mínima, obrigando os dados do entorno e a luz natural a preencher o espaço comprido, largo e baixo da sala no $3 .^{\circ}$ andar, cujas paredes laterais são recortadas, a cada poucos metros, pelas janelas em arco. A parede direita dá para o estacionamento, a esquerda dá para a rua. "Crocante" ocupou uma área retangular de um metro e meio por sete metros e meio na parede esquerda. No interior do retângulo, que atravessava à meia altura parede e janelas, o reboco liso foi chapiscado de cimento e areia e depois pintado de branco, e os vidros foram substituídos por vidros fantasia, com textura semelhante à do chapisco. 


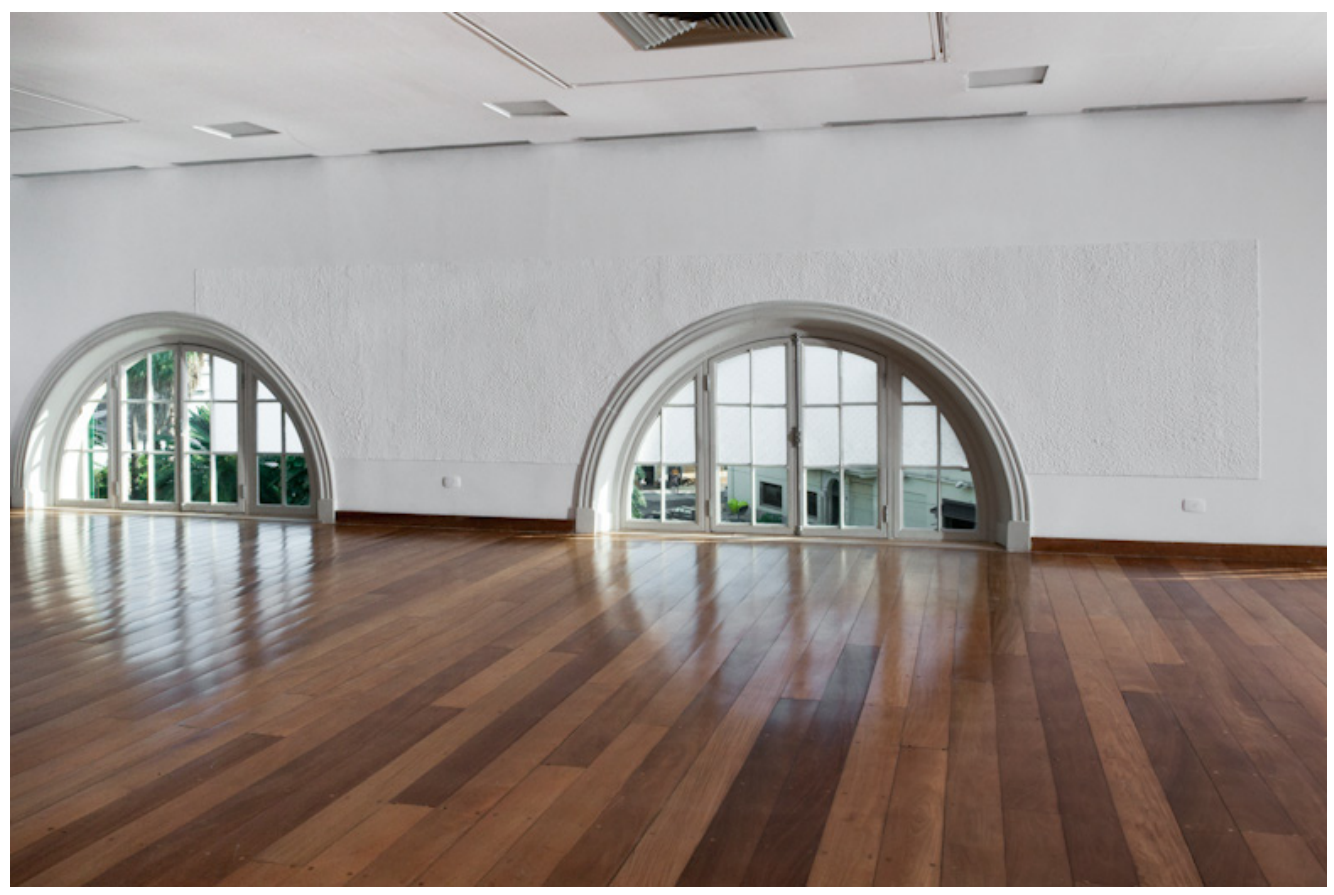

Se os vidros texturizados atrapalhavam a transparência, oferecendo alguma resistência aos dados do entorno, o chapisco na parede evocava o exterior, muros e fachadas. O trabalho duplicava a membrana do prédio, enrugando-a. Multiplicava a superfície em milhares de picos, repetição irregular e frenética, circunscrita numa área precisa, retangular, da parede que dava para a rua.

"Crocante" foi um adjetivo atribuído indistintamente a janelas e parede, vidro e reboco, numa extensão determinada de uma sala ampla de pé direito baixo que sempre esteve coberta de painéis e agora respirava, porosa.

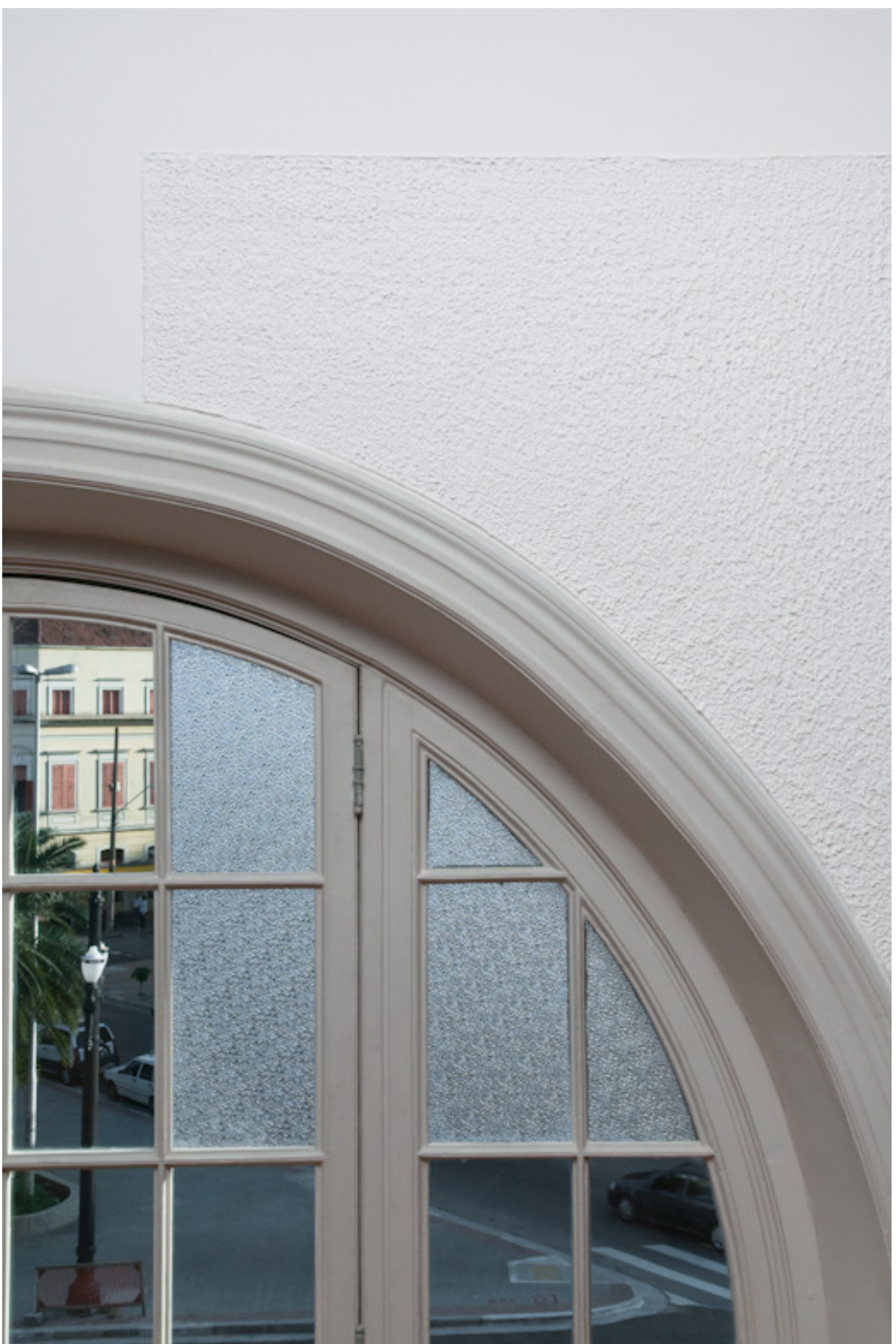


“Painel Mar” foi feito em 2011, no Pavilhão da Bienal, durante a feira sp-arte. Naquela edição da feira, as galerias foram convidadas a indicar um artista para um projeto de grandes dimensões, a ser instalado em área livre no $2 .^{\circ}$ andar do prédio. A ausência de painéis no 2. ${ }^{\circ}$ contrastava assertivamente com a ocupação dos andares de baixo, reticulados por estandes desmontáveis. Não havendo anteparos para organizar a experiência visual do visitante, já saturada, o excesso de ar e os dados crus do pavilhão agiram sobre os trabalhos, lixando-os, polindo-os, tornando-os escorregadios.

Soltos, os trabalhos se deparavam com a arquitetura do pavilhão e com o cansaço visual dos visitantes a circulá-los. Autônomos ainda que à própria revelia, devolviam especularmente cansaço e arquitetura para os seus lugares. O "Painel mar" literalmente escorregava. Era um anteparo de três metros de altura por quatro metros de largura. Uma estrutura vertical de madeira que cedia ao peso vazio do entorno e se estendia horizontalmente sobre o piso por outros quatro metros, ondulando-se para multiplicar a superfície e acomodar seus excessos. Um "L" cujo ângulo de 90 graus, antecipando o comportamento ondulado da base, suavizava-se em curva. No plano vertical, à altura dos

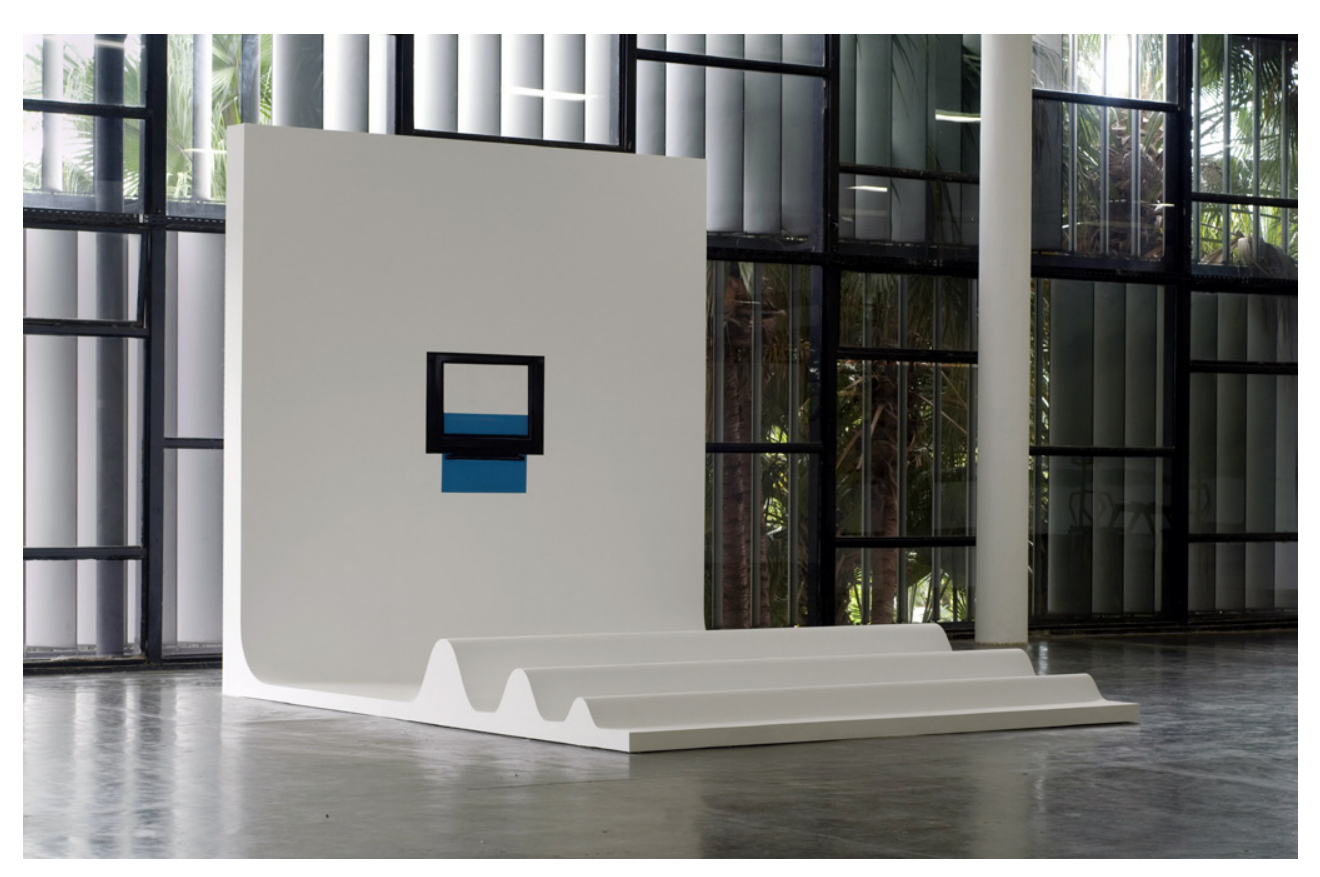

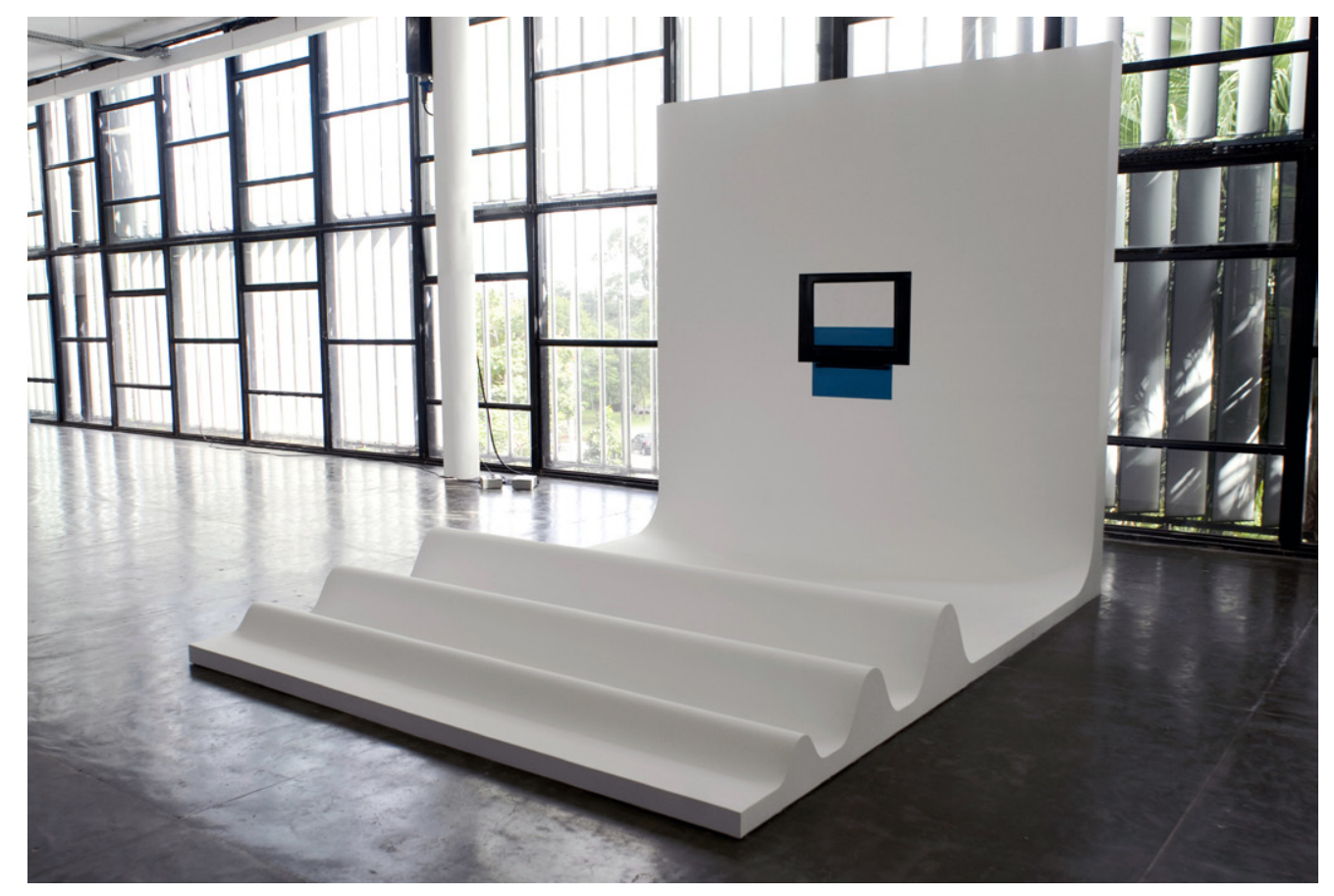

olhos, foi pintado um monitor de televisão. Sua tela, em azul de dissintonia, estava deslocada em relação ao quadro. Uma única faixa azul permanecia enquadrada, o restante do retângulo reaparecendo abaixo, sob a base do monitor.

Da televisão pintada no plano branco do painel, a tela escapava. Apenas um terço do quadro, o terço inferior, era ocupado por uma faixa monocromática, horizontal, azul de água. A base do "L" se moldava em ondas, sucessivamente mais baixas, minguando na extremidade.

O "Painel mar" era um anteparo modular que prometia ser capaz de organizar a experiência visual daqueles visitantes saturados, mas recusava a ortogonalidade. Comportava-se como os fundos infinitos usados em estúdios de fotografia, com os quais se suprimem as referências dimensionais, criandose um espaço sem escala, perfeitamente abstrato, pronto para receber horizontes figurados. 

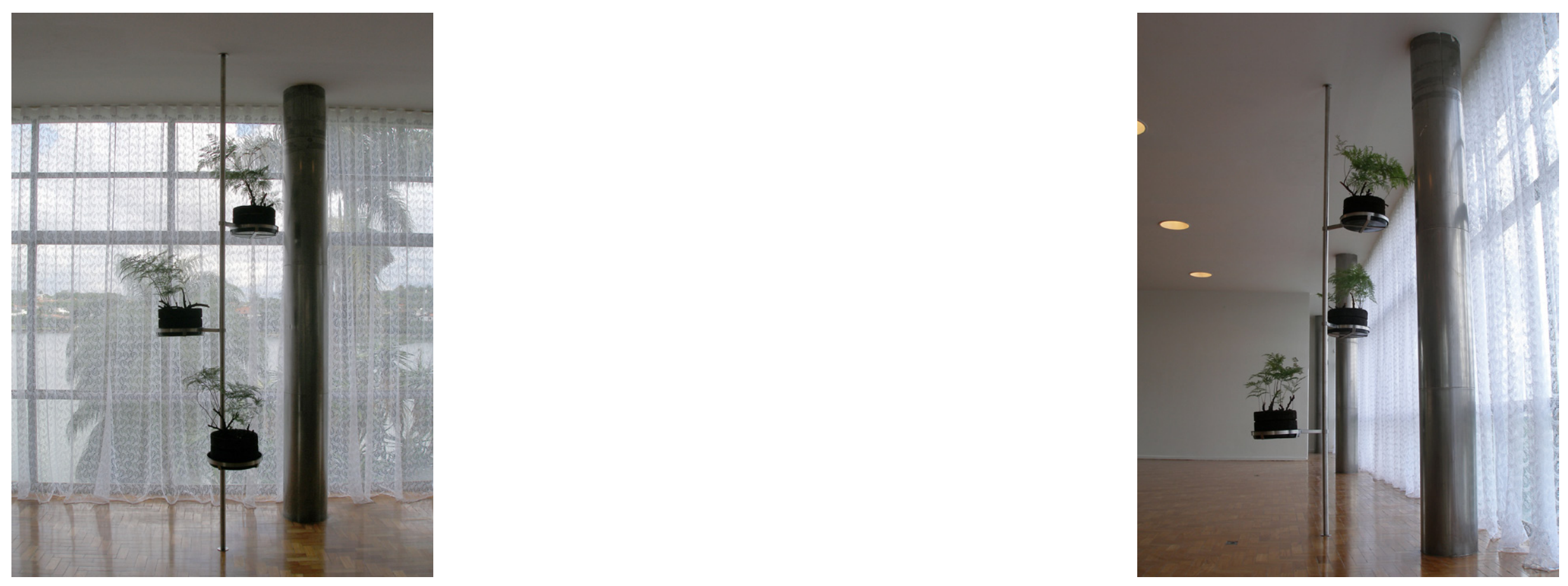

"Rendas portuguesas" é de 2007. Foi feito no Museu de Arte da Pampulha, em Belo Horizonte, na exposição que encerrou minhas atividades no programa Bolsa Pampulha. Há dois espaços expositivos no museu: salão nobre e mezanino. Do mezanino, subindo a rampa, tem-se a vista da lagoa. Tudo aponta para essa vista: a posição central, as dimensões e a inclinação amigável da rampa, as transparências e os revestimentos de aço inox e espelhos. A arquitetura é suave e sinuosa, tal como a avenida que, circulando a lagoa, conduz ao museu. As exposições dos bolsistas ocorriam no mezanino, interpostas entre o visitante e a vista.

Interposto entre o visitante e a vista, "Rendas portuguesas" consistia numa cortina de renda e numa floreira de inox com três xaxins de plantas, rendasportuguesas. A cortina cobria todo o extenso pano de vidro e, indo e vindo a cada dez centímetros, suave e sinuosa, multiplicava a superfície. Na renda, um padrão botânico, folhas de plantas, rendas-portuguesas. A floreira era

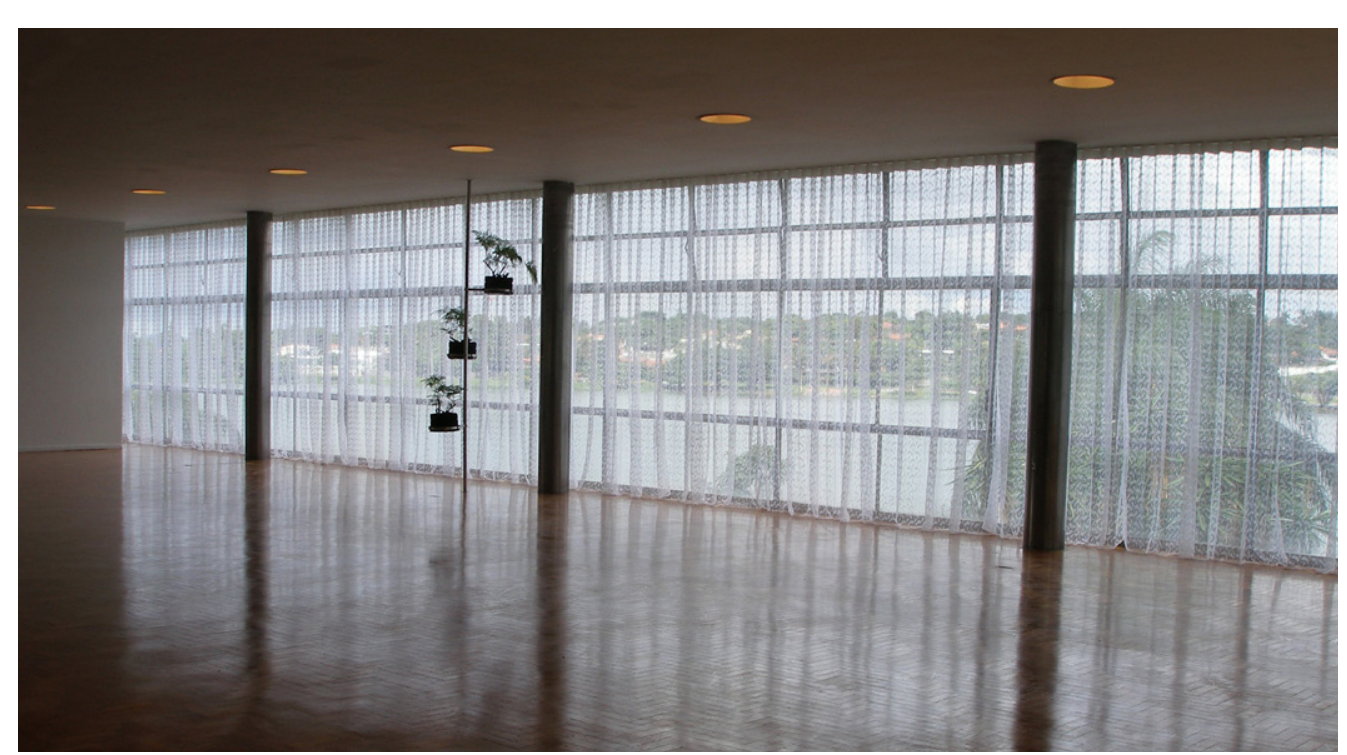


uma coluna travada entre o piso e o teto da qual se projetavam em espiral três braços com suportes. Tal como as colunas do museu, era feita de aço inox. Ela não atravessava o eixo central entre a rampa e o pano de vidro; estava deslocada para a esquerda, próxima à cortina, e convidava o visitante a se posicionar junto dela. Nos suportes, xaxins com plantas, rendas-portuguesas.

A planta pendente cujas folhas se assemelham à trama de um tecido chamase renda-portuguesa. A cortina que, no Museu da Pampulha, obstruía parcialmente a paisagem natural da lagoa era de renda. A padronagem tramada na renda se assemelhava às folhas de uma planta pendente. As folhas da planta pareciam ter sido fabricadas. A Lagoa da Pampulha, como se sabe, é artificial. Esse jogo ia e vinha, suave e sinuoso.

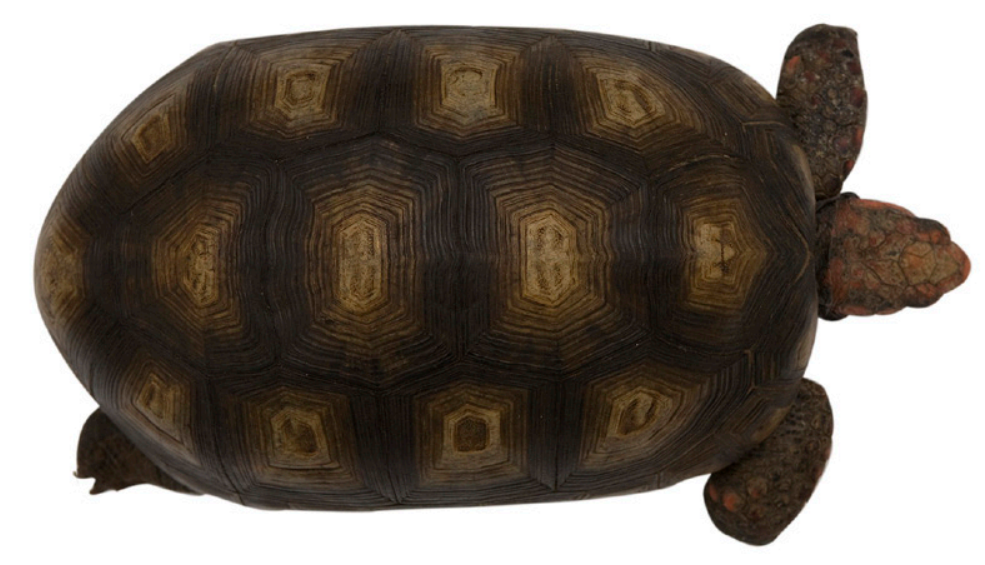

“O jabuti" é um trabalho de 2009, feito na exposição "Programa”, na Estação Pinacoteca. Os trabalhos apresentados na sala do terceiro andar instalavam-se junto às paredes: “Crocante”, chapisco e vidro, "Queimada”, papel de parede, "Cartaz", papel impresso, e "Programa”, vídeo. Todos trabalhos sem volume, seus acontecimentos restritos a uma única face perpendicular, distribuídos nas periferias da sala. Vista em planta, a sala permanecia desocupada, pontuada por colunas de sustentação, o centro um espaço de estatuto incerto, vazio mas imantado.

O jabuti foi trazido ao museu para habitar o centro por um dia. Um volume convexo de contornos afirmados, acidentado pelas formações em polígono da carapaça e pelas escamas das patas e da cabeça, que multiplicavam as superfícies de contato com o exterior, tornando-lhes espessas e extrusivas, mineralizadas. Discreta negação daqueles campos que imantavam o vazio da sala, polo móvel de repulsa que os desorganizava temporariamente à medida que se deslocava, resguardando um interior, ausente nos outros trabalhos da exposição, para onde cabeça e patas podiam recolher-se. 
VÍCIO DE LINGUAGEM

A revista sueca OEI publica poesia experimental, textos sobre arte, cinema, filosofia e sociologia.

Em três páginas duplas consecutivas da revista, inseri representações de três páginas duplas de revista, em branco. Usei desenhos digitais de uma revista aberta em páginas duplas, em branco, comprados num banco de imagens.

Nesses desenhos, sugere-se tridimensionalidade com ondulações no contorno e efeitos de luz e sombra, obtidos com a distribuição de tons de cinza em gradientes simples. Resulta uma imagem dura, simplificada, imediatamente identificável.

Enquanto as páginas da revista real tinham formato vertical, próximo ao A4, as páginas representadas eram quadradas. Ambas as páginas tinham a mesma largura. A página representada encaixava-se no centro vertical da página real, sangrando nas extremidades laterais.

Na primeira das páginas duplas dedicadas ao trabalho, distinguiam-se sob a página da direita da página dupla representada os contornos de duas outras páginas, subjacentes. Na segunda página dupla da revista real, uma página aparecia sob cada lado da dupla representada. Na terceira dupla, duas páginas subjaziam à representação da página da esquerda, restando uma única página representada à direita. À medida que se manipulavam sucessivamente as páginas da revista real, portanto, sucediam-se, como se manipuladas, as páginas da revista representada. Representava-se um movimento que, entretanto, ocorria de fato. 
A coincidência entre as larguras da página real e da página representada elevava $o$ ato de folhear à segunda potência e, assim, reiterava a presença material da revista real. O desencontro entre os limites verticais, ao contrário, descolava a página representada do círculo tautológico e reforçava a condição fantasmagórica dada pelo esvaziamento definitivo das páginas do banco de imagens, que já não convidavam à projeção de conteúdos e sustentavam em branco sua ilusão de volume. O trabalho, publicado em 2013, foi intitulado "Brochura".

A "Vistosa”, exposição feita em parceria com João Loureiro e Laura Huzak Andreato, ocorreu num pequeno galpão em São Paulo, em 2008. Para organizar o uso do espaço e as relações entre os trabalhos desenvolvidos pelos três artistas, construiu-se no galpão uma vitrine de vidro, isolando totalmente o exterior. A circulação dos visitantes se restringia a uma área intermediária cujo piso foi revestido de capacho de fibra, o material de que são feitos os tapetes de soleira. A vitrine partia da frente do imóvel, junto às duas paredes laterais, e avançava em diagonal para o interior por cerca de dois metros. Então se dobrava em ângulo oblíquo, tornando-se paralela à calçada. Antes de fechar-se, avançava para o interior ainda uma vez, agora em ângulo reto, formando um corredor estreito de um metro e meio de comprimento. No interior da vitrine, inacessível, o piso foi elevado a $40 \mathrm{~cm}$ de altura.
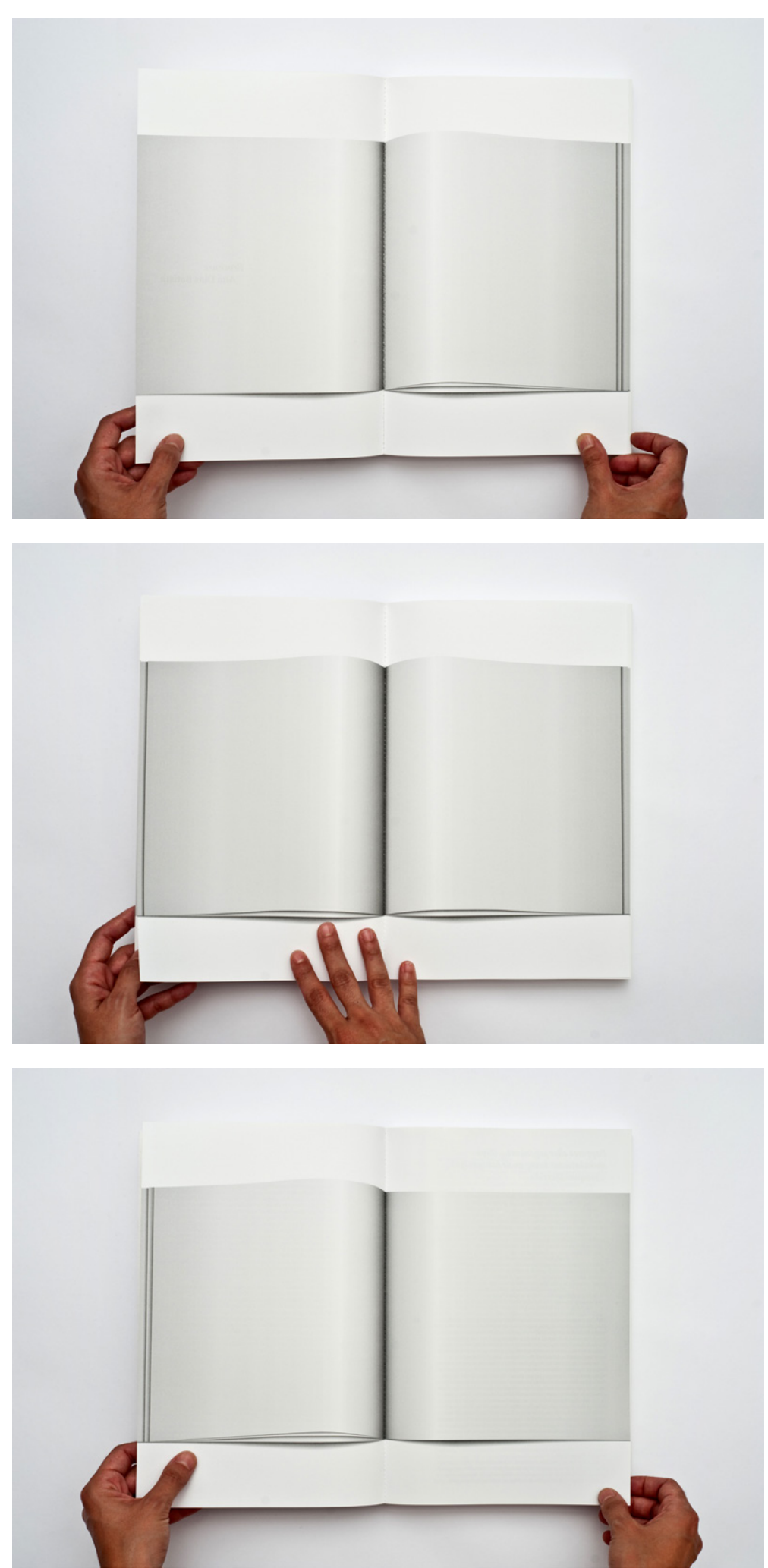

VÍCIO DE LINGUAGEM | 81 
Construí três estruturas de eucatex perfurado, a que se intitulei “1, 2, 3”, e as instalei na face direita da vitrine, que avançava em diagonal para o fundo do galpão. Acopladas no interior inacessível da vitrine primária, as estruturas eram vitrines elas também.

A primeira das vitrines acopladas estava próxima à entrada, e sua base instalava-se a cerca de $150 \mathrm{~cm}$ de altura. Ela era pequena e retangular. A frente e a face direita eram fechadas com vidro. A face esquerda não tinha fechamento. O fundo e as faces superior e inferior eram formados por chapas de eucatex perfurado brancas. Essas chapas foram forrações usuais em estabelecimentos comerciais - nos furos acoplavam-se ganchos para apresentação dos produtos. Caíram em desuso.

A segunda vitrine era maior que a primeira, e a terceira maior que a segunda. Suas bases instalavam-se, respectivamente, a $90 \mathrm{~cm}$ e $40 \mathrm{~cm}$ de altura. Ambas também tinham as frentes fechadas por vidro e as faces esquerdas abertas. Os

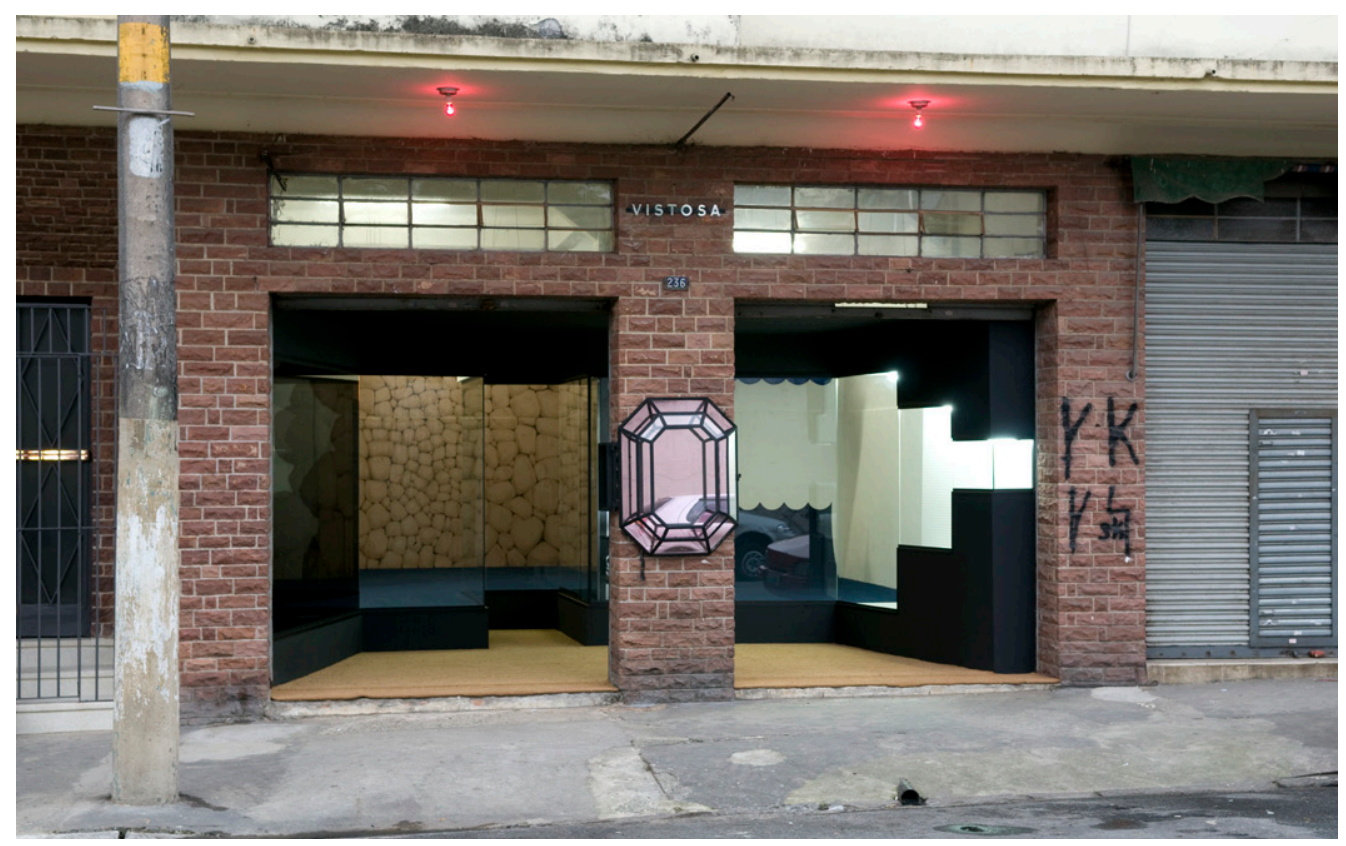

fundos, as faces inferior e superior e as faces direitas eram feitos de eucatex. Estas últimas, no entanto, possuíam um recorte vazado onde se encaixavam as vitrines anteriores, das quais pareciam derivar.

A furação das chapas de eucatex variava nas três vitrines. A primeira foi construída com a chapa perfurada convencional. Na intermediária, mais alta, mais larga e mais profunda, os furos eram proporcionalmente maiores e mais espaçados que os da primeira. Na terceira, ainda mais alta, larga e profunda que a intermediária, os furos eram ainda maiores e mais espaçados. As três vitrines eram iluminadas por lâmpadas fluorescentes, cujo comprimento e espessura também variavam. Com isso, a iluminação permanecia homogênea.

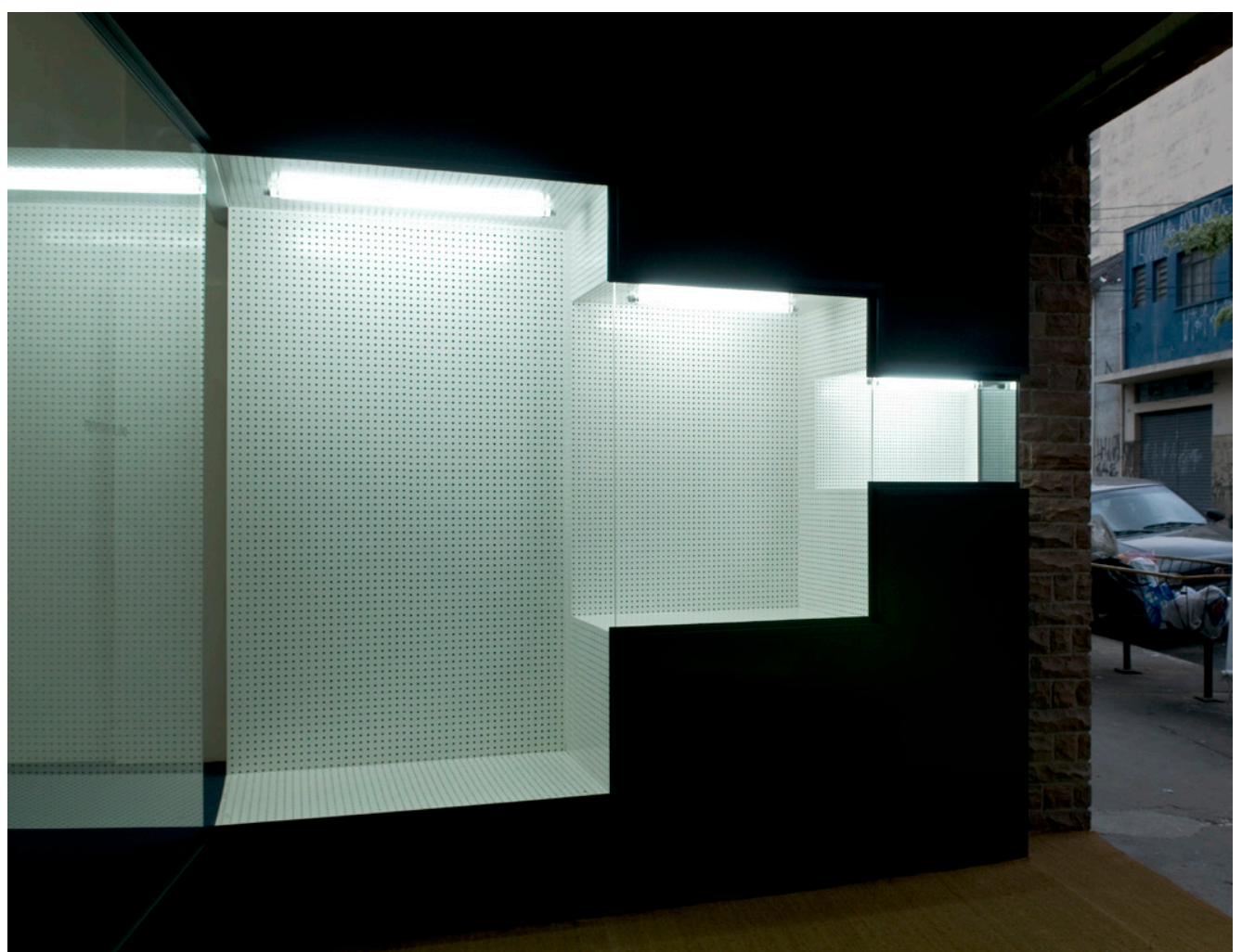

VÍCIO DE LINGUAGEM | 83 
O espaço abaixo e acima das três vitrines acopladas era vedado com chapas de madeira pintadas de preto, dando continuidade ao acabamento geral do rodapé e do topo da vitrine primária. Devido às diferenças de altura entre as vitrines acopladas, essa vedação ficava recortada, acima e abaixo, em degraus, abrindo gradualmente o campo de visão para o interior da vitrine primária.

Expunha-se um aparato de exposição no aparato de exposição que organizava aquela exposição. A encenação de uma sequência gradual relacionada ao campo de visão era ratificada pela variação nas lâmpadas e, principalmente, na furação das chapas. Mas não se tratava apenas de abrir o campo. O fato

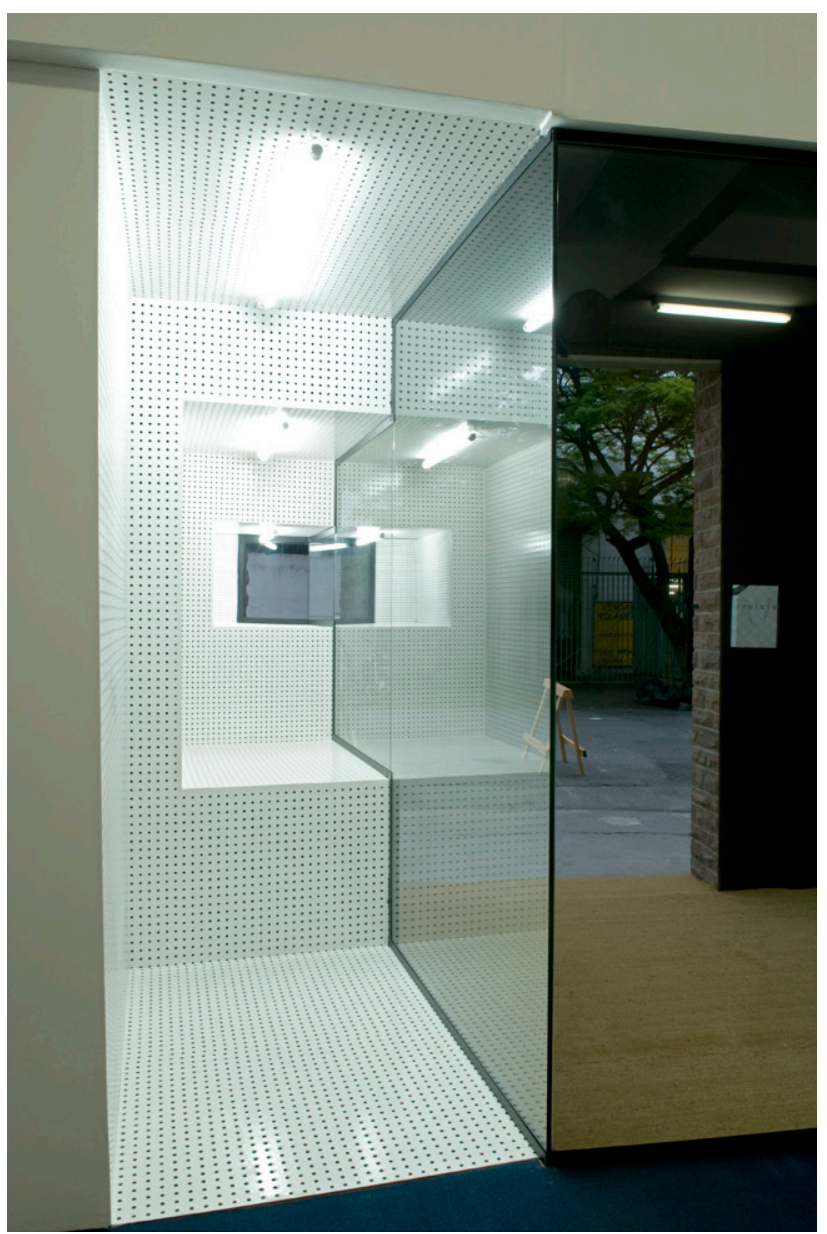

de a chapa perfurada convencional ter um padrão universalmente familiar, ainda mais naturalizado pela recente obsolescência, estabelecia um parâmetro de normalidade que as vitrines vizinhas, sutilmente, sem grande alarde, deformavam

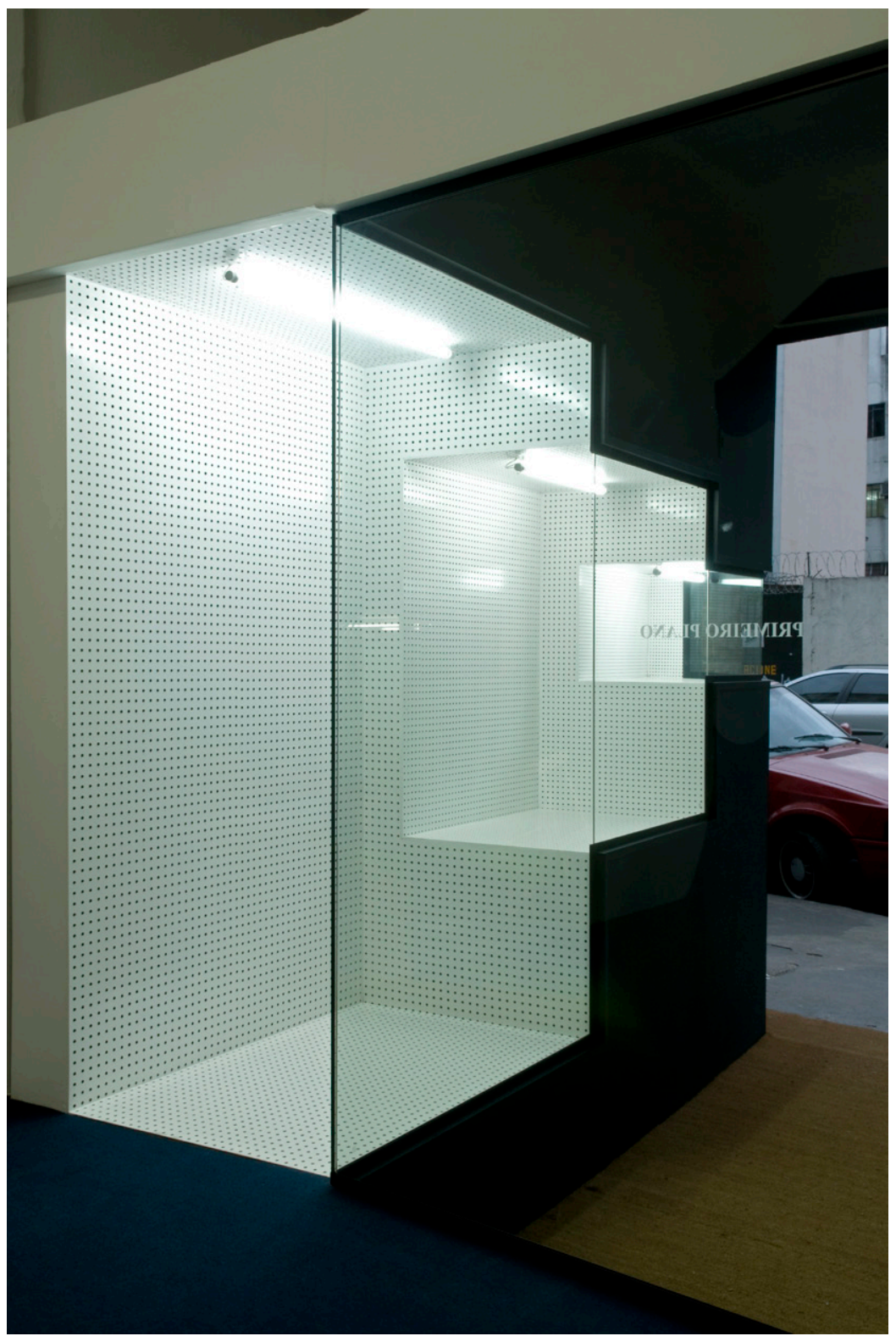

VÍCIO DE LINGUAGEM | 85 
Na sala da Estação Pinacoteca em que eu expus, há um compartimento estreito que se projeta em "u" a partir do fundo, conformando no espaço expositivo uma parede ininterrupta de 50 metros e duas paredes laterais de 3 metros de comprimento cada, com portas. Esse compartimento está centralizado na largura do espaço, restando à sua direita e à sua esquerda dois corredores simétricos.

Instalei sobre toda a superfície dessas paredes um papel de parede, no qual se reproduzia a vista de uma parede. A vista era composta por elementos reais fotografados individualmente e montados num arquivo digital, conservando suas dimensões originais. Resultava uma composição dura, imediatamente identificável.

Todos os elementos tinham pequena espessura. Eram eles: um papel de parede branco listrado de cinza, três quadros, três molduras brancas, rodapé branco e uma tomada com espelho, ambos também brancos. A altura da parede reproduzida coincidia com a da parede real. Sua largura, entretanto,
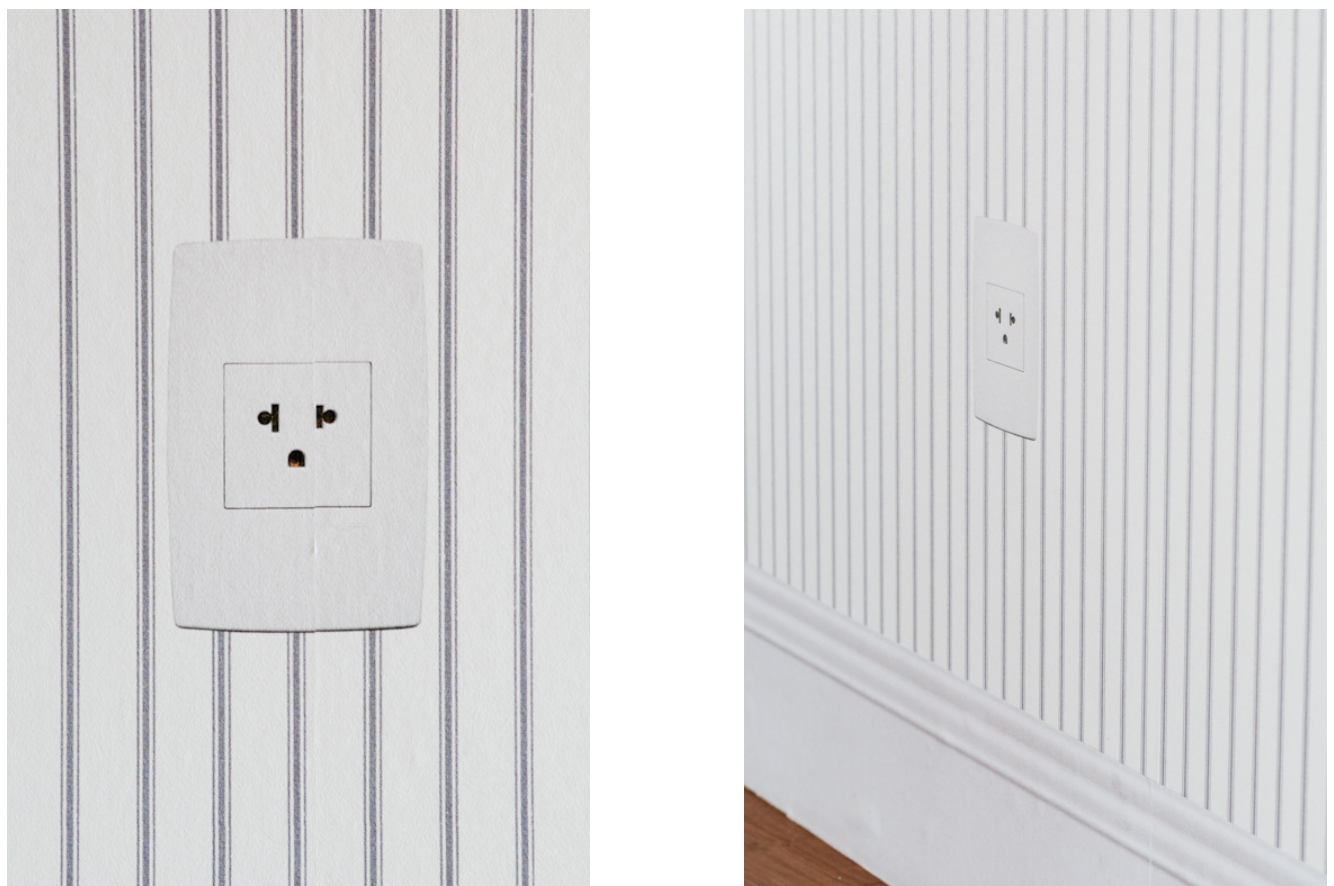

limitava-se a $250 \mathrm{~cm}$, que se repetiam em módulos idênticos ao longo dos 56 metros de paredes reais.

A vista da parede reproduzida no papel de parede aplicado nas paredes do museu não era de uma parede de museu, mas de uma parede doméstica, ainda que os três elementos mais contundentes, os quadros, à primeira vista complicassem essa constatação. Tratava-se de pinturas feitas sob encomenda, cujo motivo era enunciado no título do trabalho: "Queimada".

As pinturas eram do mesmo tamanho e dispunham-se a intervalos regulares. $\mathrm{Na}$ que ocupava o centro do módulo predominavam chamas altas, que se rarefaziam em direção às extremidades, para dar lugar, do lado esquerdo, a um trecho de céu e, do lado direito, a uma massa escura de fumaça densa.

O trecho de céu à esquerda da pintura central dava o tom à pintura à sua esquerda, em que se viam troncos queimados, cinzas fumegantes e trechos de céu. A fumaça densa na extremidade direita da pintura central, por sua vez, avançava sobre a floresta viva da pintura à sua direita.

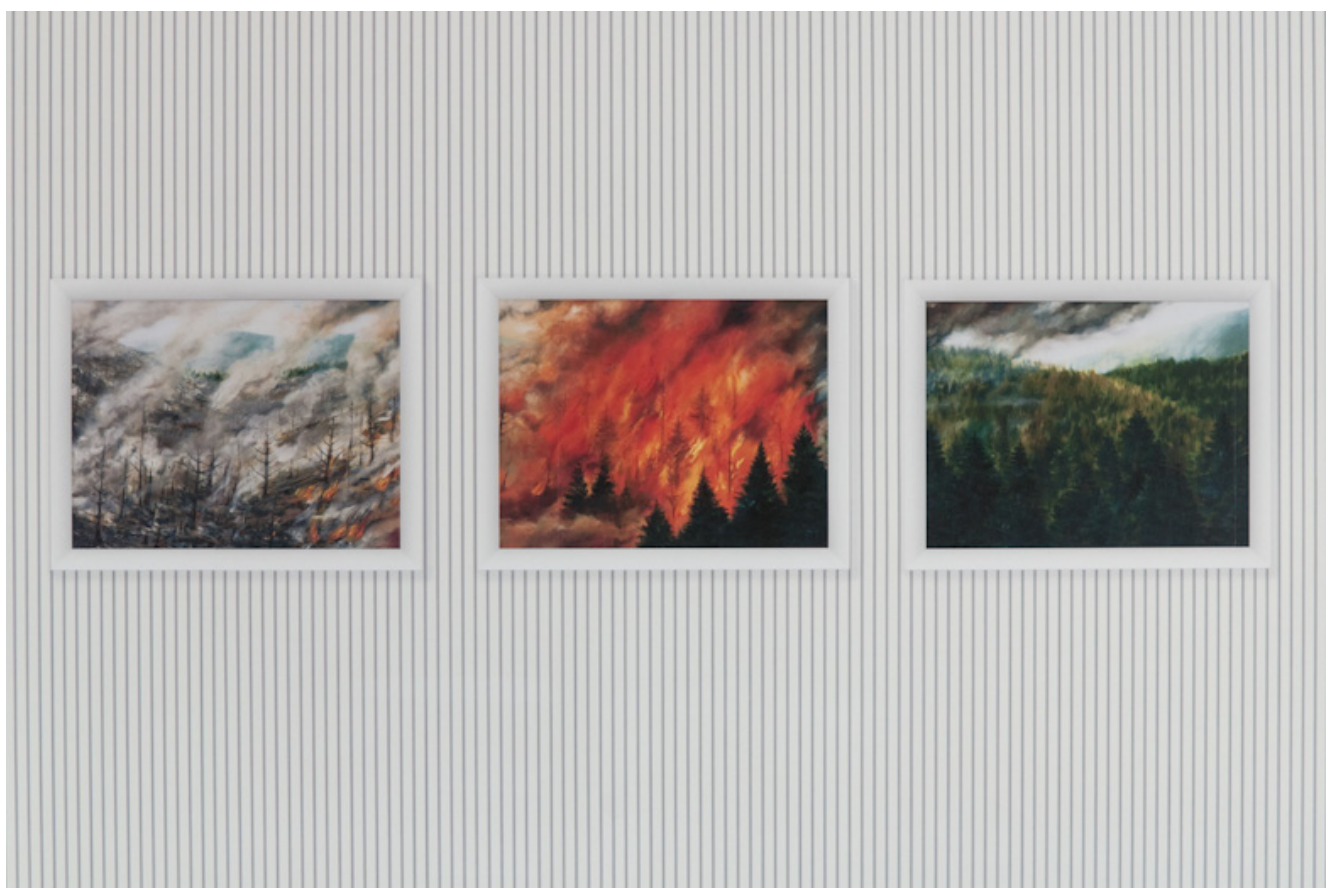


A sequência temporal dos eventos retratados nas três pinturas tornava-se circular com a repetição dos módulos. Já a indicação de que haveria um ponto de contato entre as cenas, oculto sob as faixas que as separavam na montagem da vista, engendrava outro movimento. O papel de parede listrado lançava-se
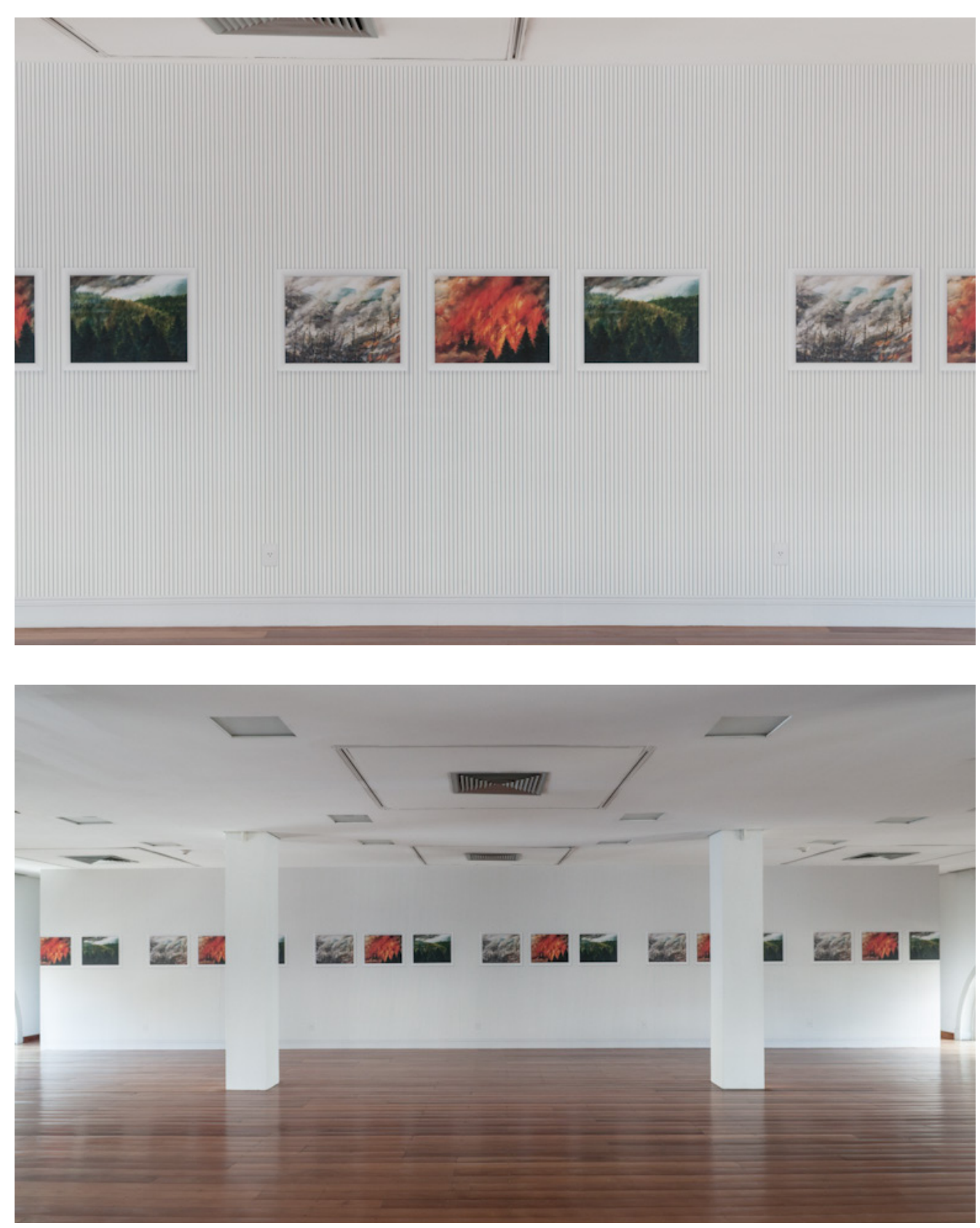

para o primeiro plano, fazendo a floresta incendiada recuar. Aqueles poucos elementos de pequena espessura oscilavam em profundidade, encenando sobreposições em suas ordens de verossimilhança.

Enquanto isso, a vista da parede doméstica reproduzida no papel de parede alcançava e ultrapassava, desencontrada, indiferente, a extremidade da parede frontal, dobrando pinturas em ângulo reto e seguindo nas duas paredes laterais.

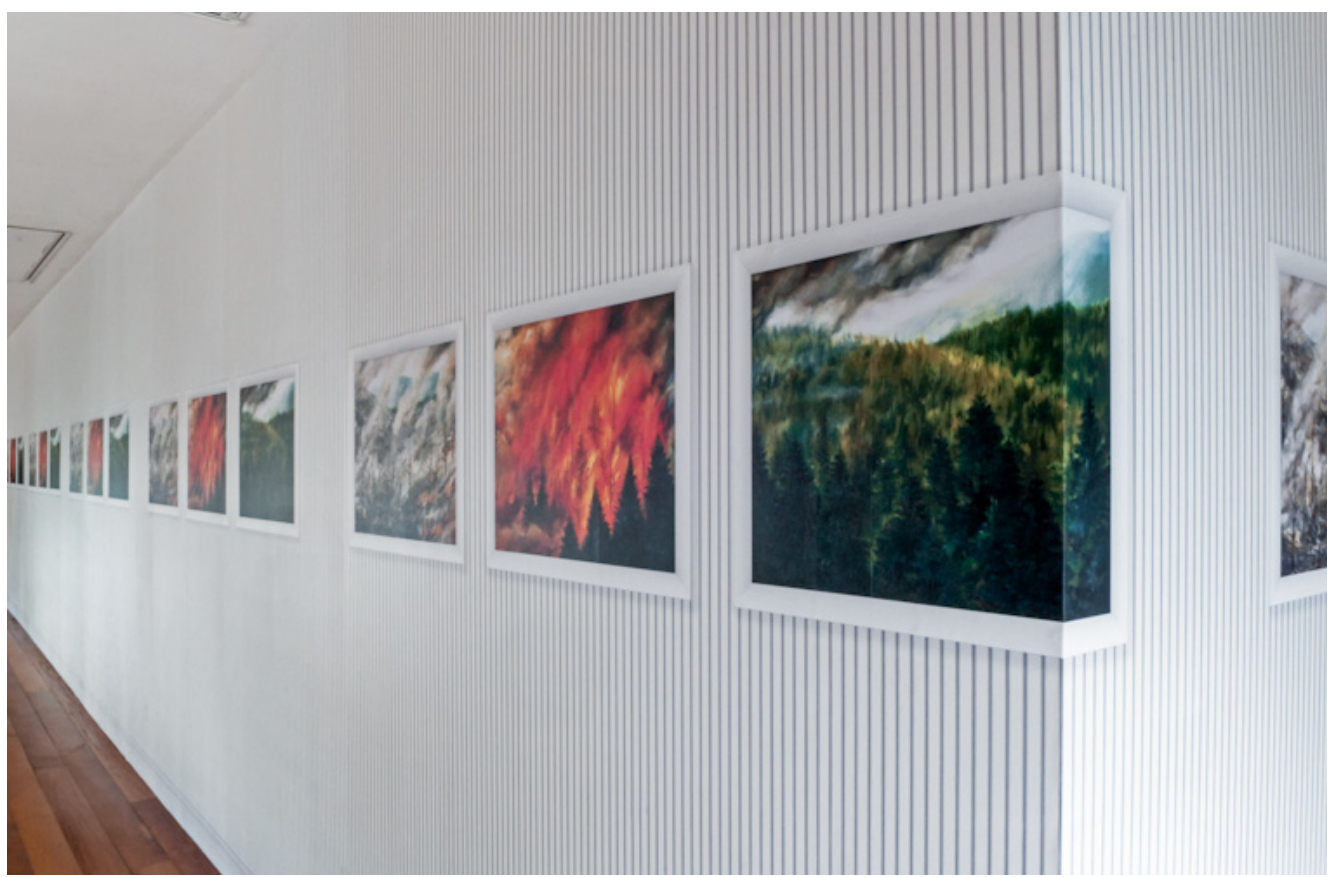

Encenação. "Por que estão tentando estragar, em nome de uma verdade comum, afinal, esse prodígio de uma realidade que nasce, evocada, atraída, formada pelo próprio cenário?” (O Pai, em Seis personagens à procura de autor, de Pirandello.) 

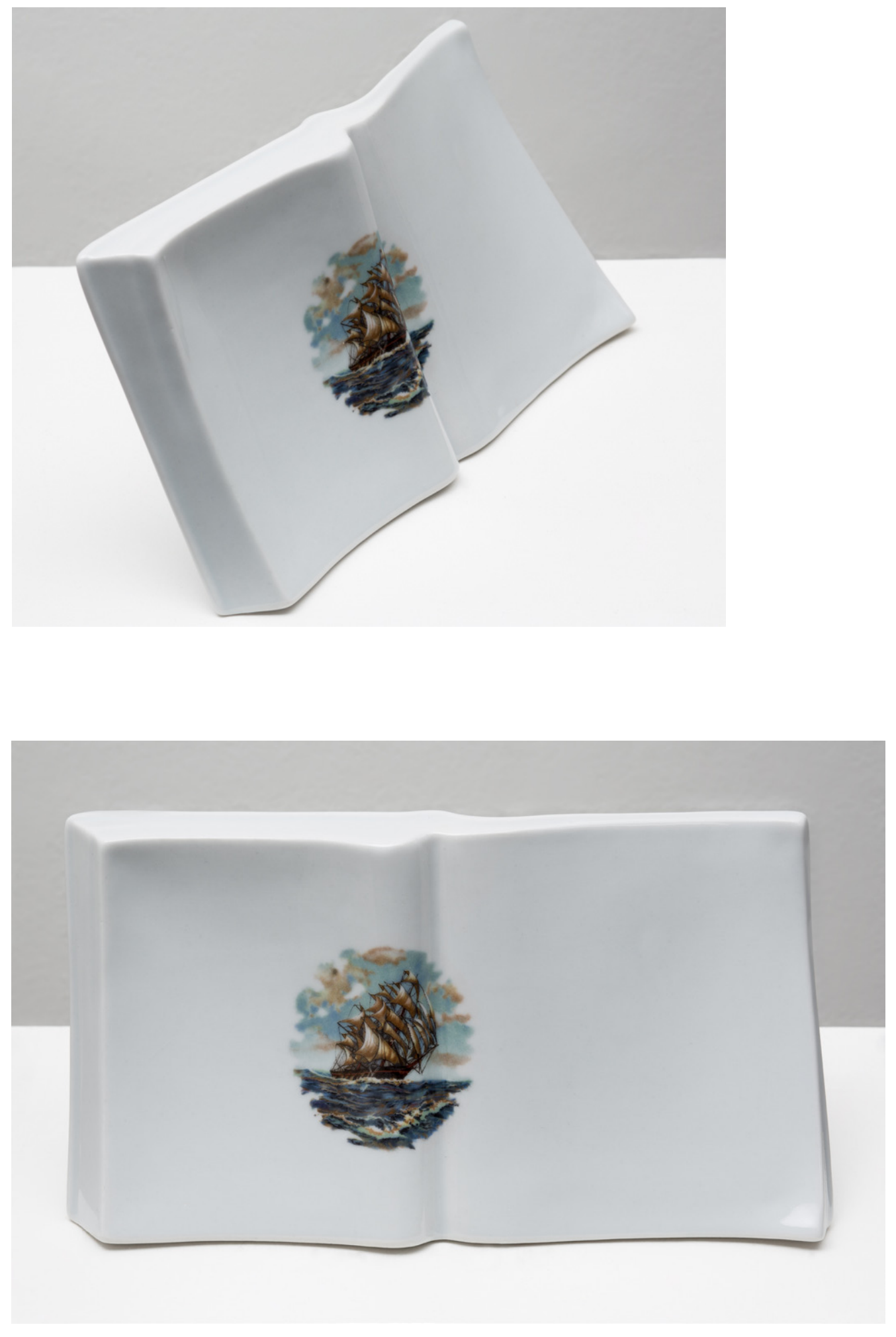

\section{IMPLICAÇÃO MÚTUA}

"História" é um objeto decorativo de porcelana branca comprado pronto. Ele tem a forma de um livro aberto, de pé, ligeiramente inclinado para trás, como se apoiado num cavalete. A frente tem curvas e ondulações, simulando em porcelana o caimento leve do papel. Ela costuma ser decorada com ornamentos e mensagens (poemas, aforismos, salmos, congratulações) pintados ou decalcados.

Em "História", foi aplicado um decalque para porcelana comprado pronto. A aplicação não respeitou os limites das duas páginas do livro; o decalque foi posicionado a meio caminho entre elas, moldando-se à dobra central. Ele é circular e se dissipa nas extremidades irregularmente, resultando um contorno impreciso, que ressalta o tratamento expressivo da figura. A figura é uma caravela navegando, nuvens no céu, mar agitado. Velas infladas, a caravela parece deslocar-se em velocidade da esquerda para a direita, de perfil.

Moldando-se às ondulações na face do objeto de porcelana, face que simula as páginas de um livro aberto e talvez reverbere a superfície de um mar agitado, o decalque redondo, cujos contornos reiteram o tratamento pictórico da figura que delimitam, parece deslocar-se da esquerda para a direita em velocidade, sofrendo os efeitos de um fenômeno da natureza implicado na cena que reproduz.

Os livros de história desconhecem essa deriva. 
O "Escalímetro" é o objeto que seu título designa. Um instrumento de medição linear em forma de prisma triangular, contendo em cada face duas graduações correspondentes a diferentes escalas numéricas. Todas as graduações utilizam o metro como unidade de medida e aplicam a ele uma redução: na escala 1:50 cada metro é reduzido 50 vezes; na 1:100, 100 vezes. Ele é usado para aferir distâncias e transferir medidas em representações reduzidas de razão fixa, mapas, plantas, desenhos técnicos, modelos, maquetes.

O objeto que o título do "Escalímetro" designa, tal como os elementos a cuja aferição se destina, parte de uma abstração e tem grandeza variável. Mas as variações de grandeza dos elementos a cuja aferição ele se destina são sempre relativas, ao contrário das suas. Tal como os elementos a cuja aferição se destina, ele é encontrado em tamanhos convencionais. Mas, diferentemente daqueles elementos e a despeito de sua aplicabilidade universal, seus tamanhos convencionais são apenas dois: 30 e 15 cm de comprimento.

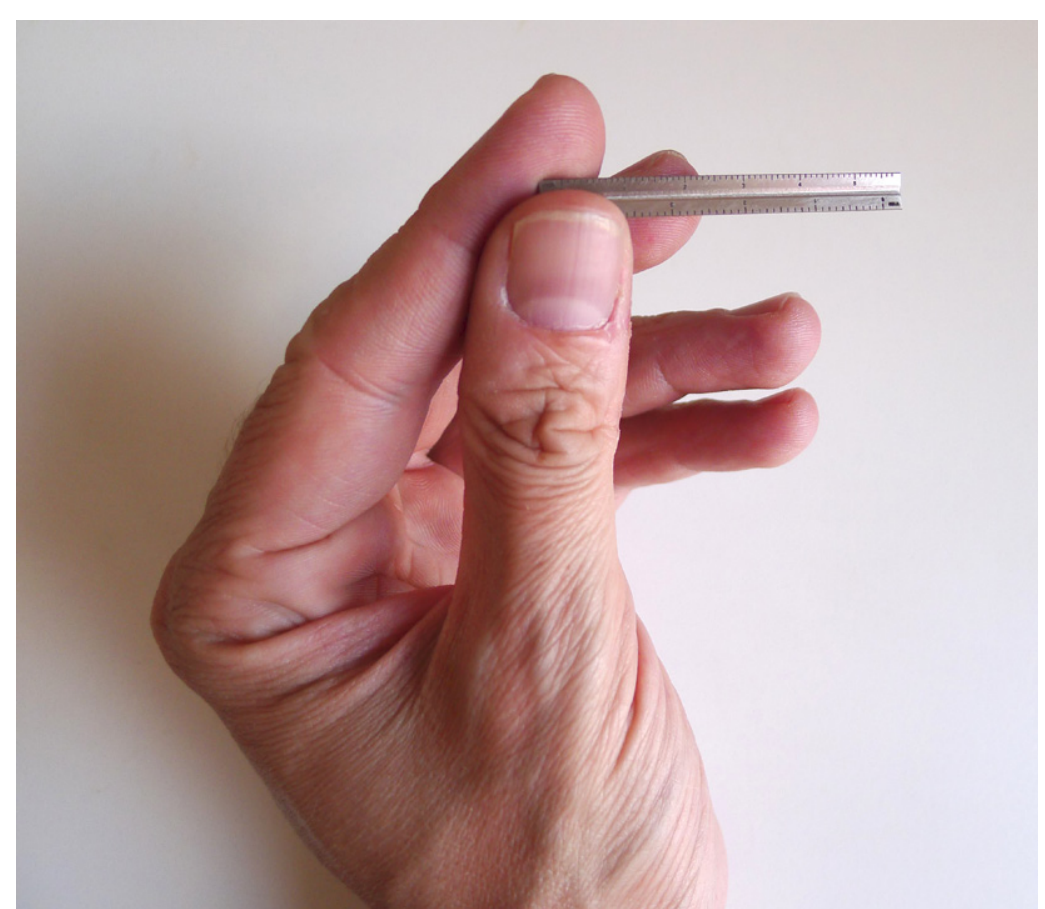

O "Escalímetro" tem $5 \mathrm{~cm}$ de comprimento, cada face tendo apenas $5 \mathrm{~mm}$ de largura. Sobre essas faces são gravadas, em fontes minúsculas e com perfeita exatidão, as seis escalas de redução convencionais: 1:100, 1:125, 1:75, 1:50, $1: 25,1: 20$.

Tal como os elementos a cuja aferição se destina, o Escalímetro sofreu uma redução de razão fixa. Mas, diferentemente daqueles elementos, miniaturizado, ele não passou a representar o objeto que seu título designa.

O "Escalímetro" ainda é um instrumento de medição linear em forma de prisma triangular, contendo em cada face duas graduações correspondentes a diferentes escalas numéricas.

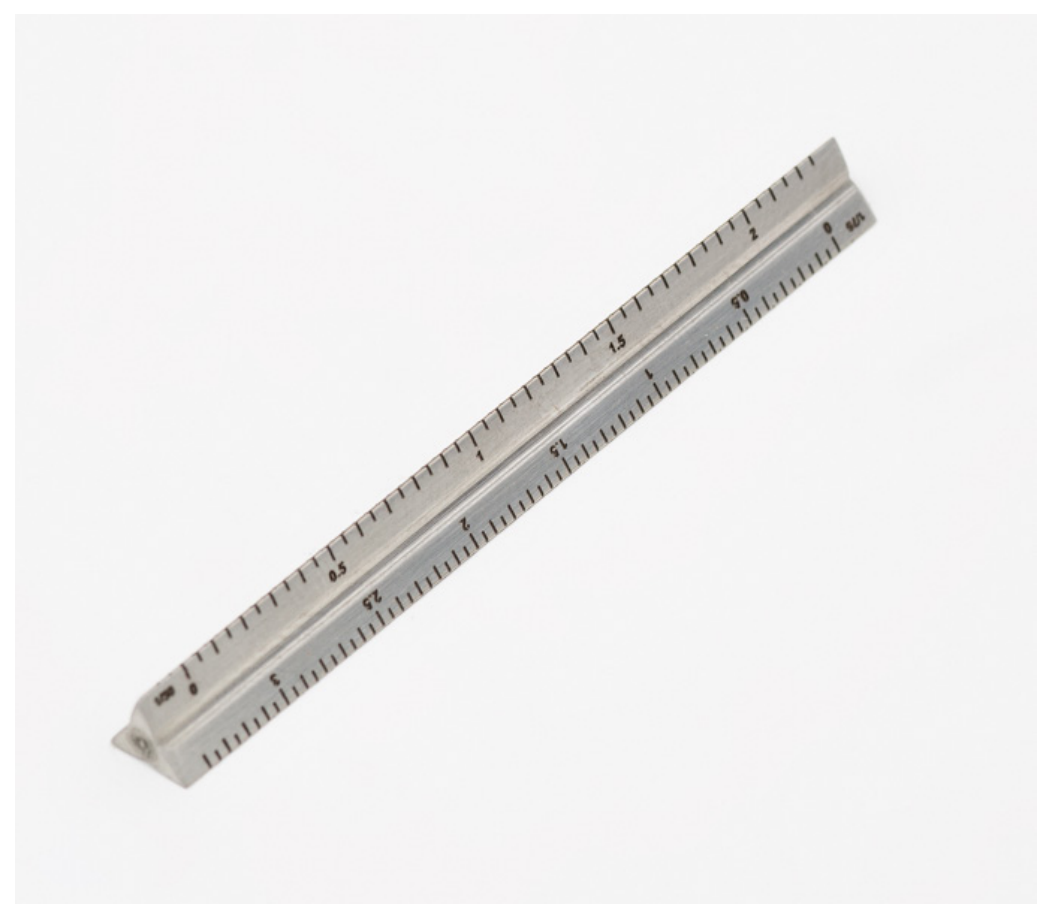


"Com efeito": uma faixa de papel kraft de alta gramatura, uma bola de boliche. A faixa tem um metro e sete centímetros de largura e dezoito metros e vinte centímetros de comprimento, as dimensões oficiais de uma pista de boliche. Uma de suas extremidades é presa no chão com fita adesiva, a outra está enrolada em bobina. A bola pesa treze libras, é preta e tem marcas de uso. Está sobre a faixa de papel a alguns metros da extremidade presa no chão. Ali contém, pesada, o avanço da bobina.

Pistas de boliche são tradicionalmente feitas de madeira. Seguem especificações rigorosas quanto ao tipo da madeira, o encaixe das tábuas, o tratamento da superfície, especificações que garantem regularidade aos efeitos da bola. Em “Com efeito", o material de que são feitas as pistas não é propriamente substituído, reposto, mas perde densidade, se rarefaz.

À medida que perde densidade, a pista parece assumir um comportamento do objeto que é sua função amparar: mimetiza as revoluções da bola. Rebobinase, viciada, não se sabe se na memória de seu referente ou nas propriedades de seu material: papel kraft, comercializado em bobinas. À bola, efetivamente marcada por arremessos, revoluções e impactos, cabe agora resistir às pressões da pista figurada.

Nada se move, com efeito, embora o efeito obtido seja de movimento.

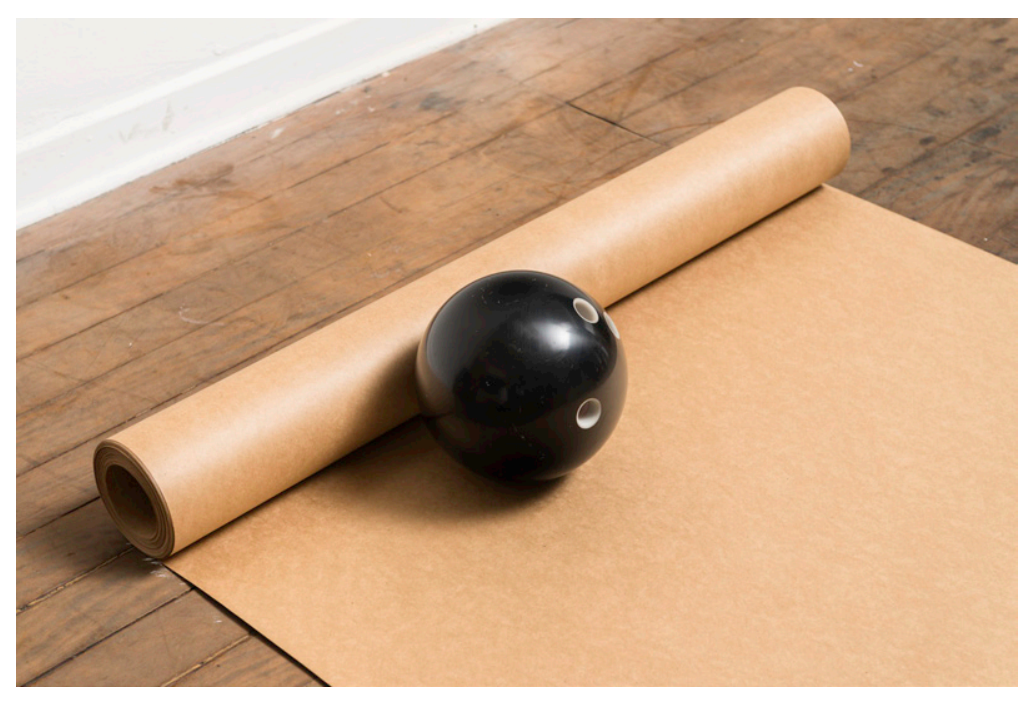

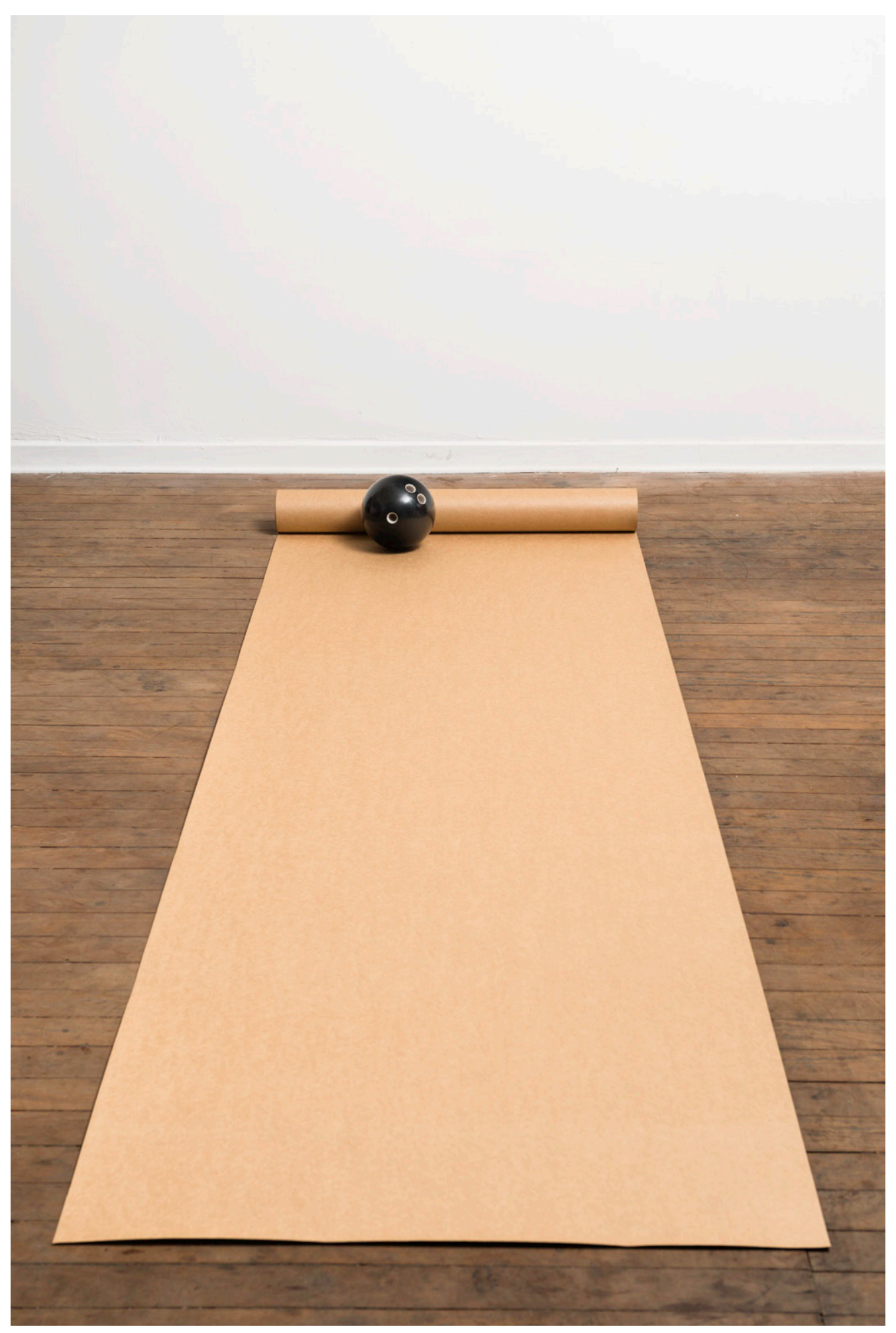

VÍCIO DE LINGUAGEM | 95 
Os "Fotolitos: Desembaçadores" são fotolitos para impressão offset, produzidos em bureau especializado, a partir de um arquivo digital.

$\mathrm{Na}$ impressão offset, transfere-se uma imagem original por meio de gravação a laser para uma cópia intermediária de alto contraste em filme de acetato transparente, o fotolito. Além da imagem original, costumam-se acrescentar ao fotolito linhas de corte, marcas de registro, identificação do arquivo, escalas de tons: elementos que servem ao controle do processo de impressão, descartados no produto final.

O fotolito é posicionado entre uma mesa de luz e uma chapa previamente preparada com emulsão fotossensível. A luz emitida pela mesa atravessa as áreas transparentes do fotolito e grava a chapa, cujas áreas expostas se tornam, por uma reação química, hidrófilas e repelentes à gordura. A tinta utilizada na impressão é gordurosa e adere apenas às áreas correspondentes às linhas ou manchas positivas do fotolito. O fotolito funciona, portanto, como máscara para a gravação da chapa. Seu papel no processo é de mediação.
Os "Fotolitos: Desembaçadores" são desenhos lineares em escala real, feitos com base nas disposições dos fios elétricos acoplados nos vidros traseiros de carros.

Num carro, quando os desembaçadores elétricos são acionados, os fios se aquecem e impedem que a diferença de temperatura entre o interior e o exterior cause condensação de umidade, embaçando a janela traseira. A disposição dos fios obedece a cálculos de eficiência, ao mesmo tempo em que, como na maioria das peças de carro, tem um componente arbitrário, ligado à identidade visual do modelo. São tantas as disposições desses fios quantos são os modelos de carros. Trata-se, no entanto, de um elemento discreto que, para funcionar, mais do que afirmar a própria presença deve tornarse imperceptível, assegurando a transparência da janela, seu suporte. Sua visibilidade é inversamente proporcional à eficácia.

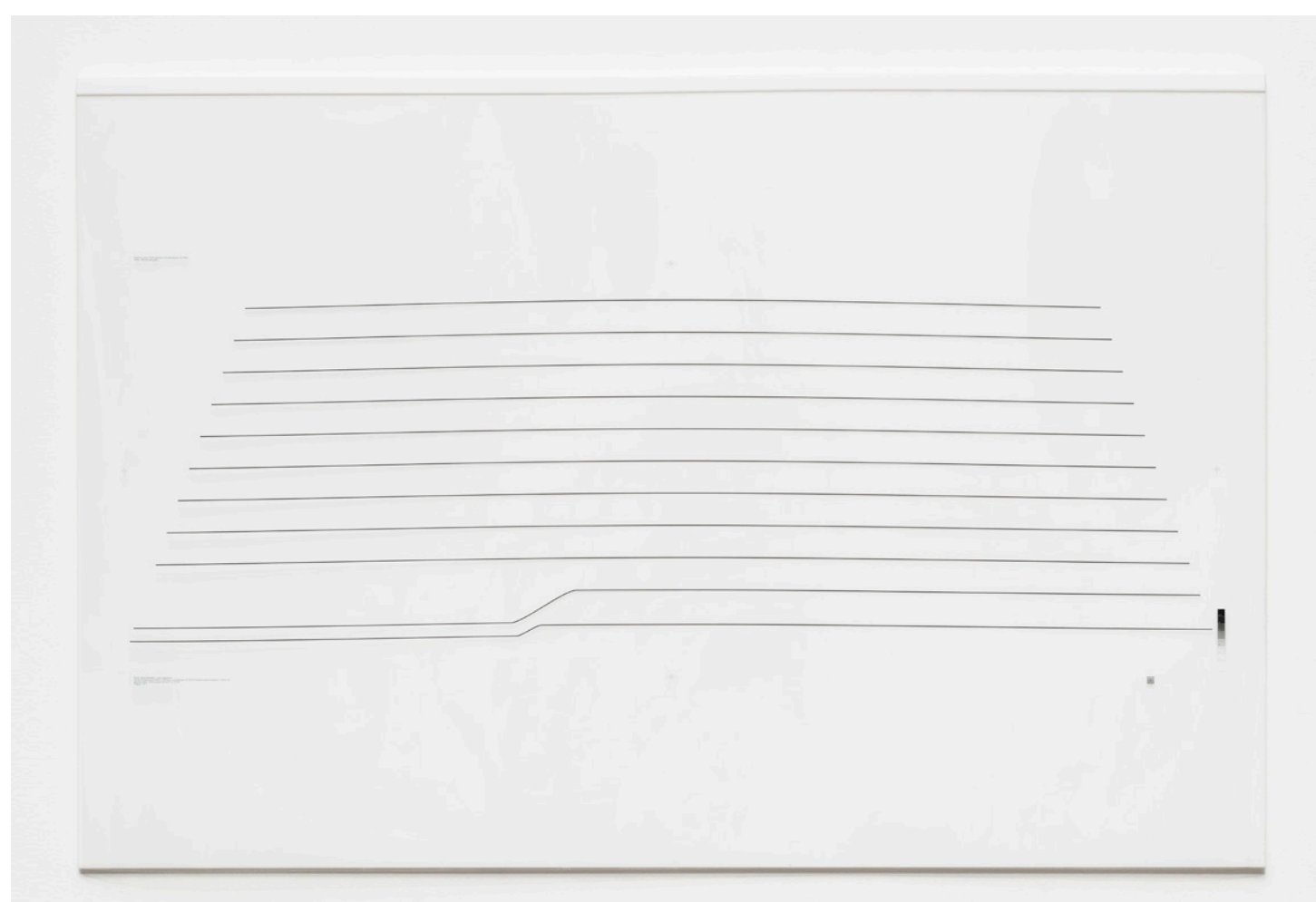


Os "Fotolitos: Desembaçadores" são cópias intermediárias em suporte transparente para a reprodução em série de imagens originais. As

imagens originais que elas copiam são desenhos lineares de alto contraste reproduzidos em série, em finos fios elétricos sobre suporte transparente, nos desembaçadores de carros. A esses desenhos se agregam, emancipados de sua vigência limitada, os elementos de marcação - linhas de corte, sinais de registro, escalas e identificação.

A reprodutibilidade, finalidade do processo de impressão offset, retrocede para a própria natureza do desenho original, desenho que ainda assim se insiste em copiar. Ou é a natureza do desenho original que avança, convertendo-se em promessa de reprodutibilidade no material que lhe dá corpo, promessa que, ainda assim, não se cumpre. A finalidade reverte-se em premissa. A cópia intermediária, em produto final. A transparência, em afirmação opaca do suporte, que não se pode mais atravessar.

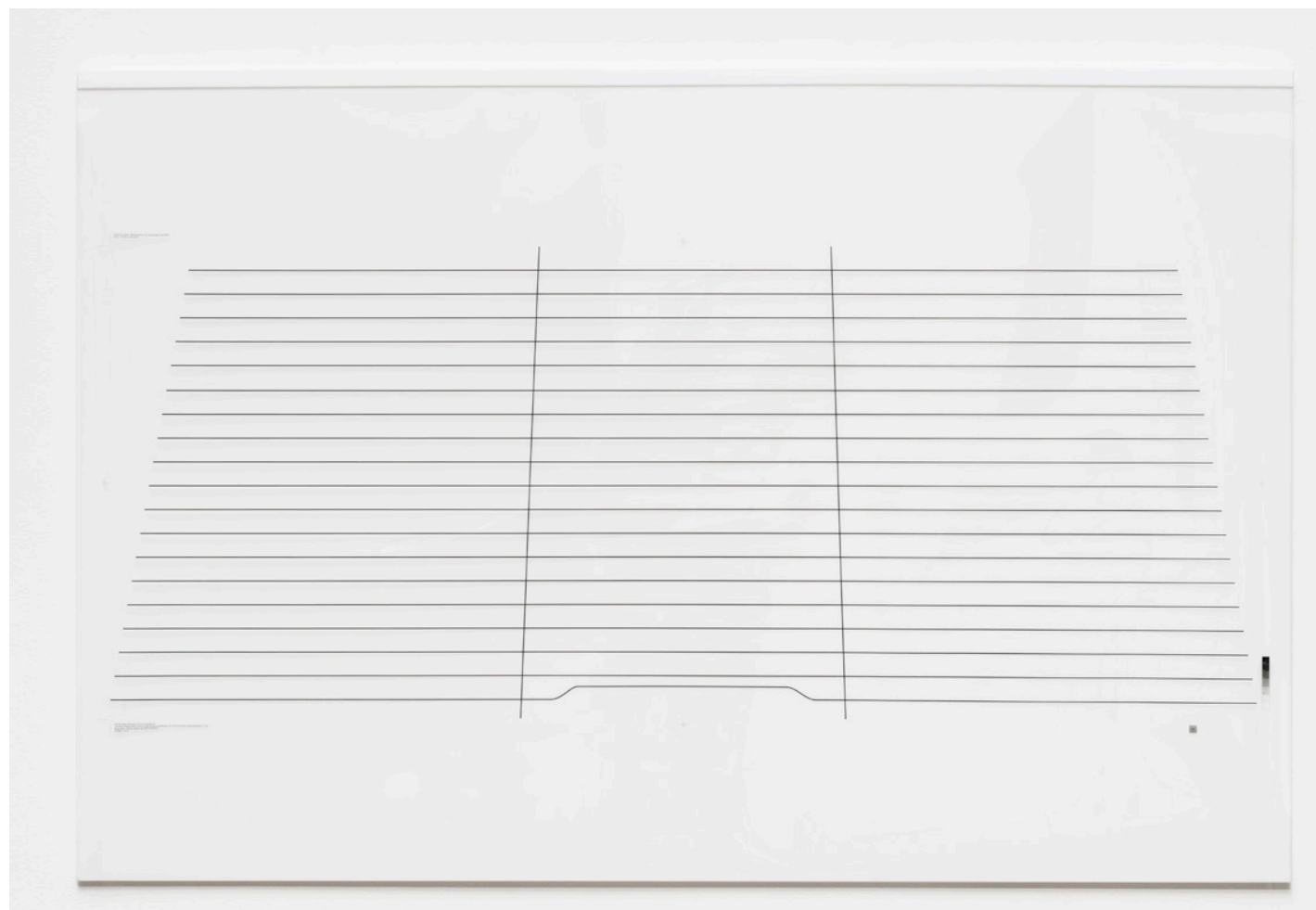

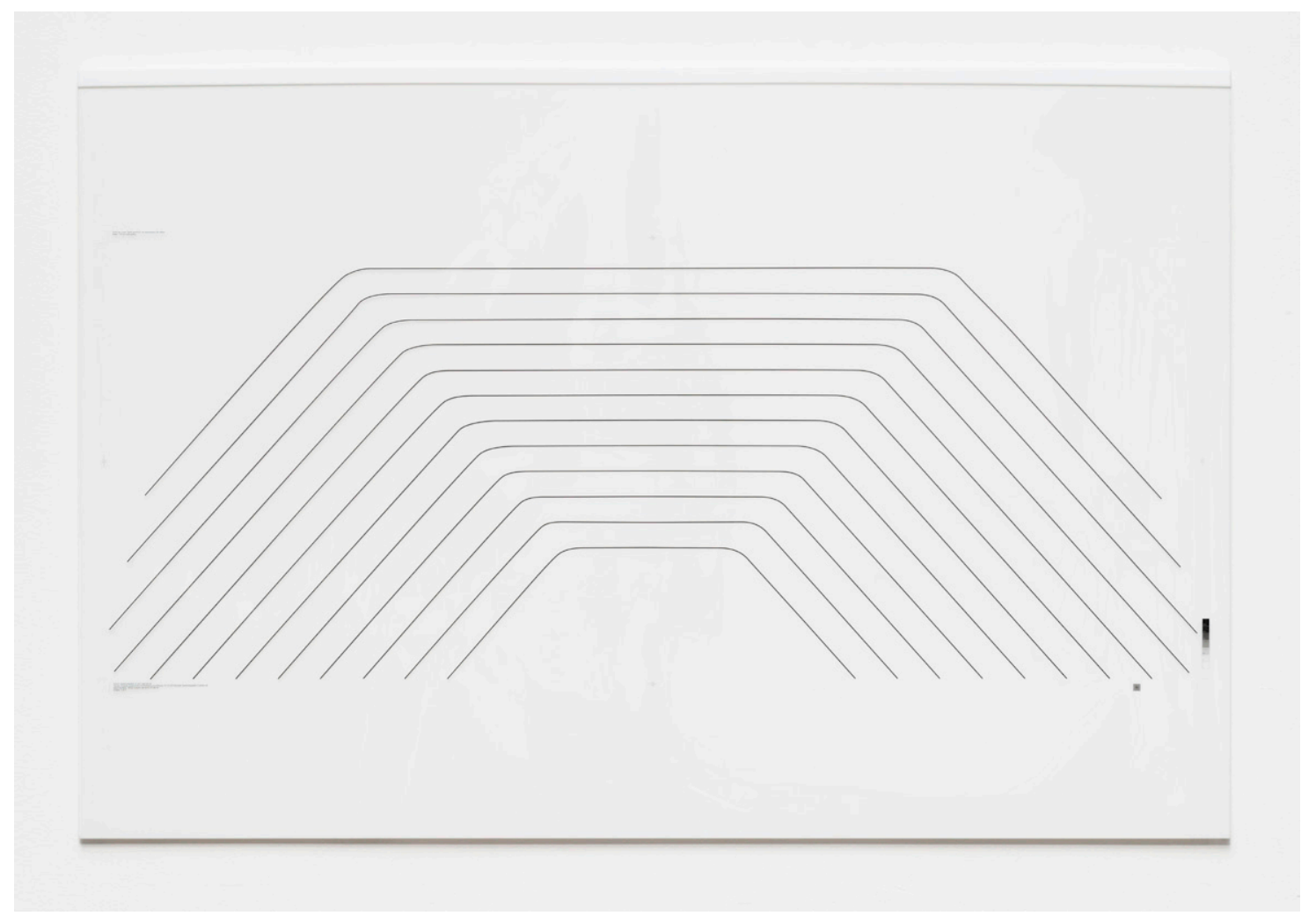


SEQUÊNCIA

A primeira folha é ocupada por pequenos círculos, idênticos, dispostos em grade. Um padrão fechado e uniforme que recobre toda a página e sangra nas extremidades.

Na folha seguinte, o mesmo padrão reaparece restrito a uma área retangular. Há faixas em branco no topo, na base e nas laterais da página, simétricas.

$\mathrm{Na}$ terceira folha, no interior daquela área retangular, algumas sequências de círculos desaparecem: quatro linhas inteiras depois da primeira; a $21^{\mathrm{a}}$ linha, a $38^{\mathrm{a}}$ e a $57^{\mathrm{a}}$. Formam-se cinco grupos autônomos.

Na quarta folha, os cinco grupos se mantêm, mas alguns círculos desaparecem: os doze primeiros e os doze últimos da primeira linha, que constituía um grupo isolado; os quatro primeiros das primeiras linhas dos quatro outros grupos; e os 24, 7, 19 e 7 últimos, respectivamente, da última linha de cada um desses mesmos grupos.

Na quinta folha, mantido o primeiro grupo, desaparecem linhas inteiras, alternadas, entre a primeira e a última de cada um dos outros quatro grupos.

Na sexta folha, o conjunto todo é arrastado para baixo. A configuração dos três primeiros grupos se mantém. O quinto grupo, empurrado contra a base da página, se desfaz, seus círculos acumulados desordenadamente. O quarto grupo estaria inteiro se três círculos não escorregassem da última linha.

$\mathrm{Na}$ sétima folha, o conjunto é novamente arrastado para baixo. O quarto grupo estaria desfeito se as duas primeiras linhas não se mantivessem. Os círculos abaixo delas se acumulam em desordem. Os círculos acima delas mantêm, em linha, sua configuração. 
$\mathrm{Na}$ oitava folha, conjunto arrastado, é o terceiro grupo que atinge a base, desfazendo-se.

Na nona folha há quatro linhas íntegras: a linha única do primeiro grupo e as três primeiras do segundo.

Na décima folha todos os círculos se acumulam desordenadamente na base da página.

Numa primeira sequência, executada entre a primeira e a quinta folhas, os círculos se converteram de pontos indiferentes de uma retícula virtualmente infinita a caracteres particulares de um texto, dividido em título e parágrafos. Como nenhum círculo foi deslocado ou acrescentado, havendo apenas

subtração, pode-se afirmar que os caracteres de texto subjaziam aos pontos do padrão reticulado.

Numa segunda sequência, executada entre a sexta e décima folhas, os círculos se converteram de caracteres de um texto a unidades autônomas, desencadeadas. Nenhum círculo foi subtraído ou acrescentado, havendo apenas deslocamento. Teria entrado em ação algo como uma força de gravidade fictícia, atraindo os círculos ao limite físico da base da página.

Tomadas as duas sequências, nenhum círculo foi acrescentado, havendo apenas subtração e deslocamento. A conversão dos círculos de pontos de uma retícula a unidades autônomas talvez tenha despojado o espaço da página de abstrações. Mas é preciso ter em conta que essa conversão se fez à custa do acréscimo de uma ficção, e com a mediação encenada da linguagem.

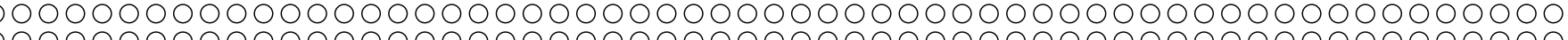

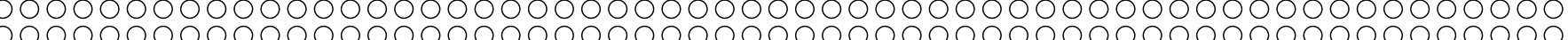
० 0000000000000000000000000000000000000000000000000000000000 T0000000000000000000000000000000000000000000000000000000000

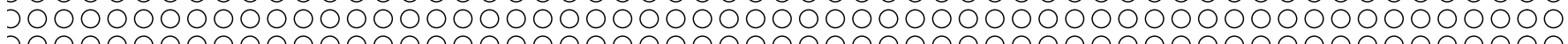
50000000000000000000000000000000000000000000000000000000000 20000000000000000000000000000000000000000000000000000000000 50000000000000000000000000000000000000000000000000000000000

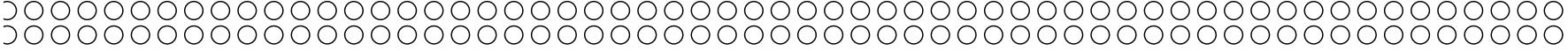
0 0 0 0000000000000000000000000000000000000000000000000000000

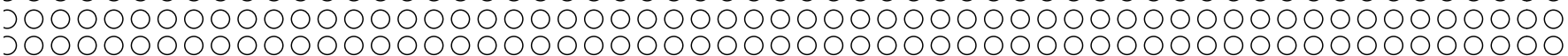
00000000000000000000000000000000000000000000000000000000000

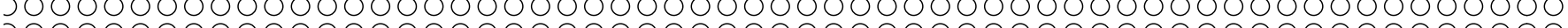

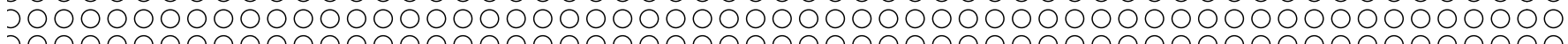

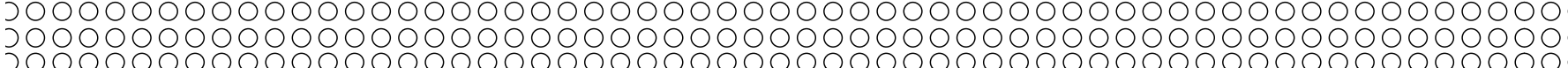
, 0000000000000000000000000000000000000000000000000000000000 50000000000000000000000000000000000000000000000000000000000

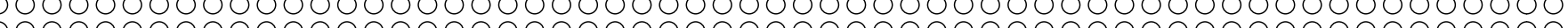
10000000000000000000000000000000000000000000000000000000000

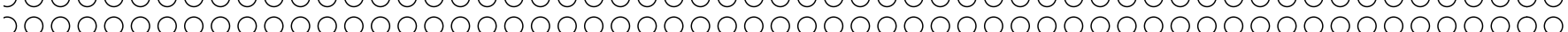
00000000000000000000000000000000000000000000000000000000000 , 0000000000000000000000000000000000000000000000000000000000

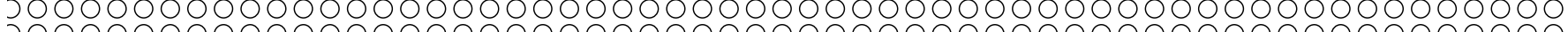
年

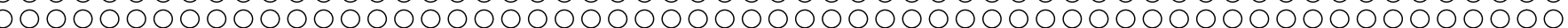
ए 0000000000000000000000000000000000000000000000000000000000 20000000000000000000000000000000000000000000000000000000000

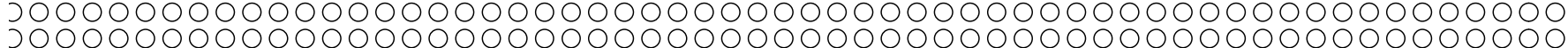

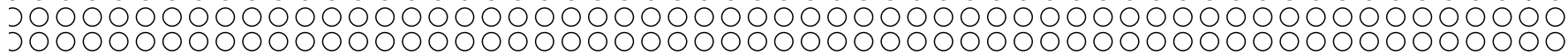
20000000000000000000000000000000000000000000000000000000000

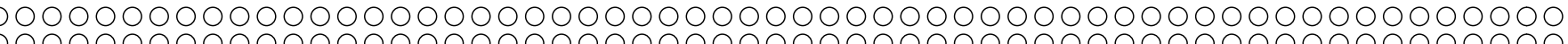

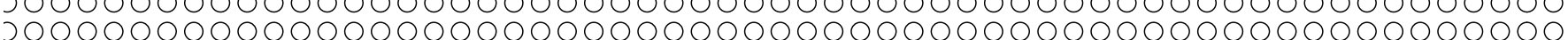

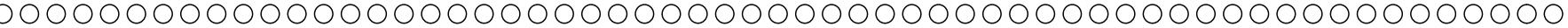
,

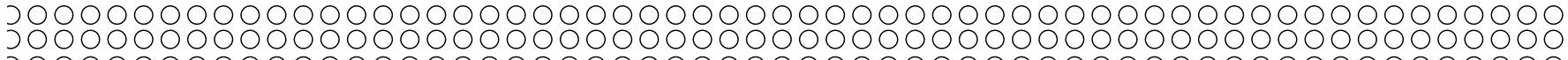

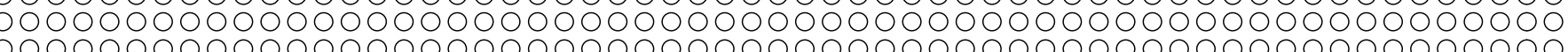
ए 0000000000000000000000000000000000000000000000000000000000

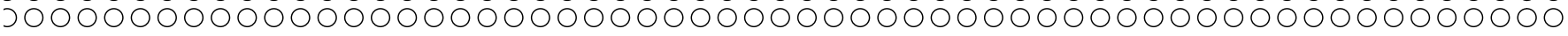
(10000000000000000000000000000000000000000000000000000000000 年

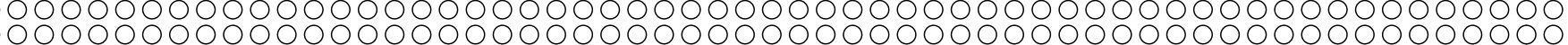

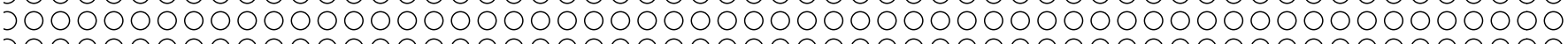
30000000000000000000000000000000000000000000000000000000000 $\begin{array}{llll}0 & 0\end{array}$

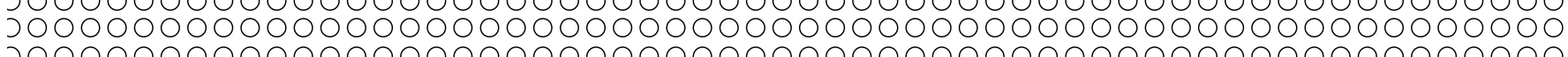
50000000000000000000000000000000000000000000000000000000000

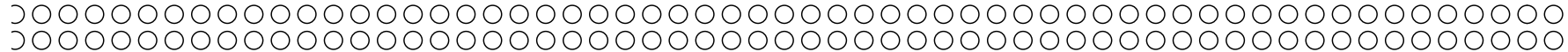

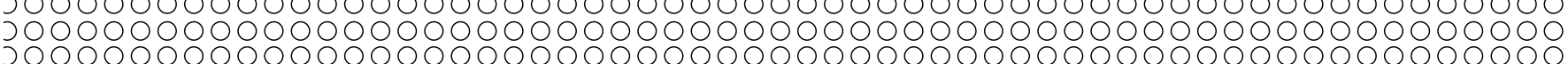
50000000000000000000000000000000000000000000000000000000000 20000000000000000000000000000000000000000000000000000000000

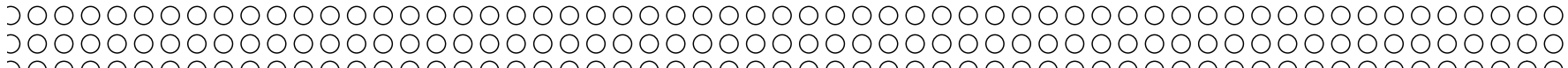

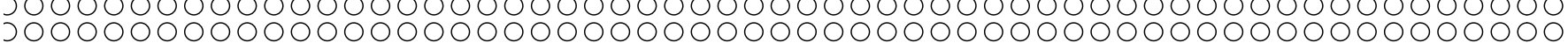

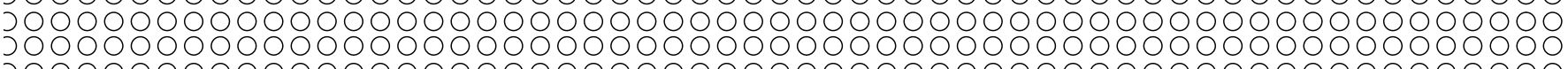

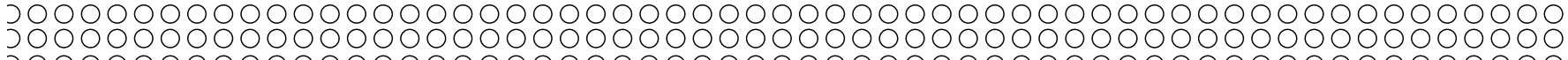


000000000000000000000000000000000000000000

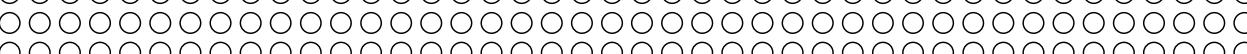

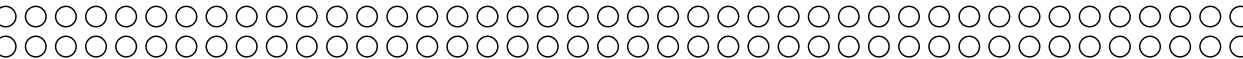
000000000000000000000000000000000000000000

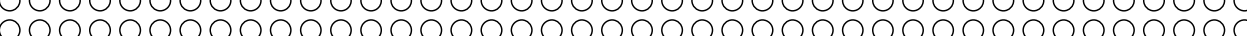

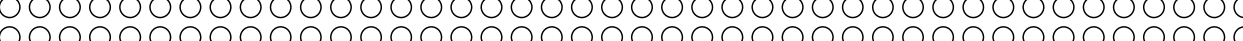
000000000000000000000000000000000000000000

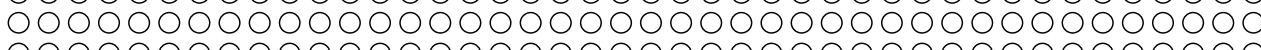

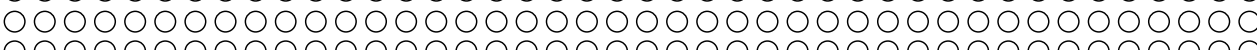

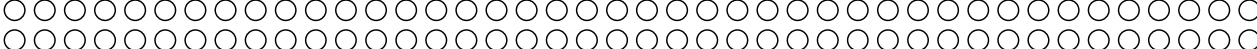
0 0000000000000000000000000000000000000000 000000000000000000000000000000000000000000 ०00000000000000000000000000000000000000000 O 000000000000000000000000000000000000000000 000000000000000000000000000000000000000000 000000000000000000000000000000000000000000 000000000000000000000000000000000000000000

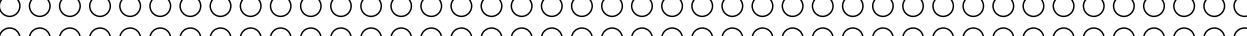

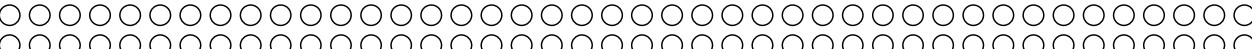
○० 000000000000000000000000000000000000000000 000000000000000000000000000000000000000000 法 000000000000000000000000000000000000000000 000000000000000000000000000000000000000000 ०00000000000000000000000000000000000000000

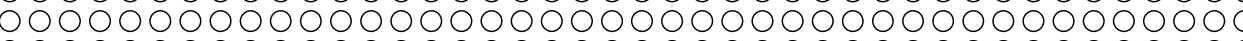

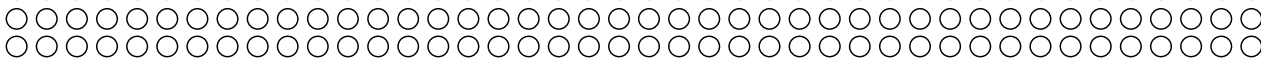
0000000000000000000 000000000000000000000000000000000000000000

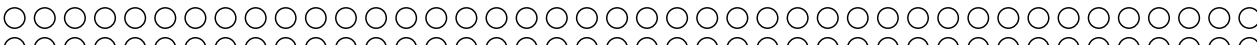
年

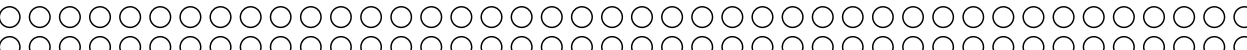

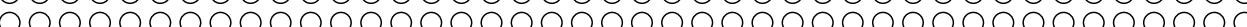

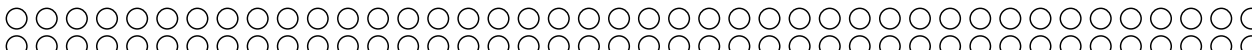
000000000000000000000000000000000000000000 O 00000000000000000000000000000000000000000 000000000000000000000000000000000000000000 000000000000000000000000000000000000000000 000000000000000000000000000000000000000000

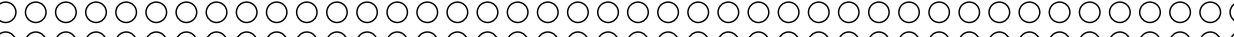
000000000000000000000000000000000000000000 000000000000000000000000000000000000000000 000000000000000000000000000000000000000000

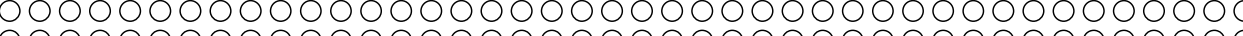
每

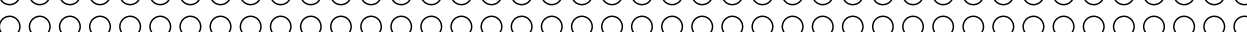
000000000000000000000000000000000000000000 000000000000000000000000000000000000000000

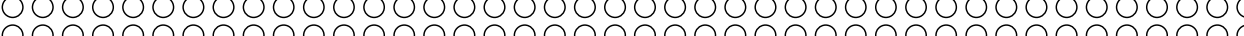
०००००००००000000000000000000000000000000000 000000000000000000000000000000000000000000 
000000000000000000000000000000000000000000 o 000000000000000000000000000000000000000000 000000000000000000000000000000000000000000 000000000000000000000000000000000000000000

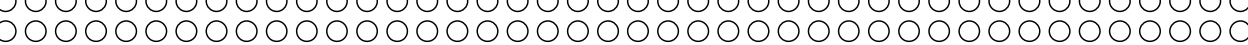
(1) 000000000000000000000000000000000000000000

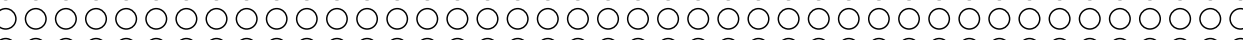

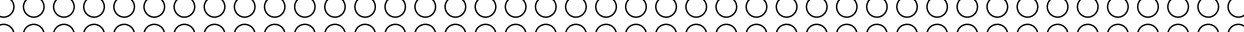
0.0000000000000000000000000000000000000000 000000000000000000000000000000000000000000

000000000000000000000000000000000000000000 000000000000000000000000000000000000000000 000000000000000000000000000000000000000000 000000000000000000000000000000000000000000 000000000000000000000000000000000000000000 年 000000000000000000000000000000000000000000 000000000000000000000000000000000000000000 000000000000000000000000000000000000000000 000000000000000000000000000000000000000000

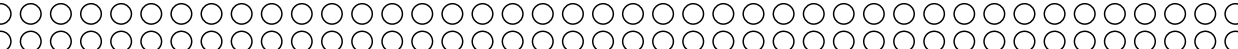
000000000000000000000000000000000000000000 000000000000000000000000000000000000000000 000000000000000000000000000000000000000000

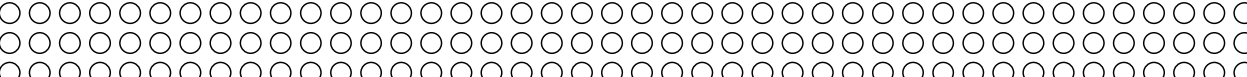

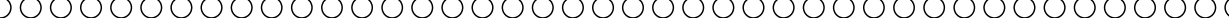

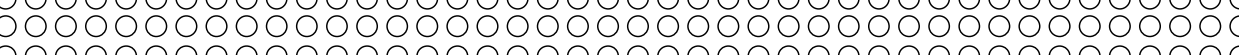
000000000000000000000000000000000000000000

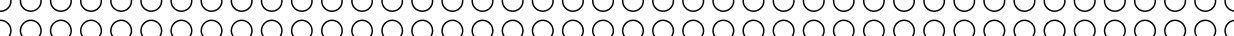
000000000000000000000000000000000000000000 000000000000000000000000000000000000000000

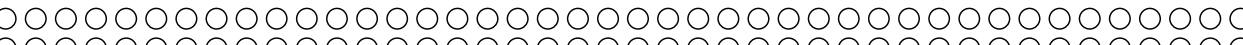

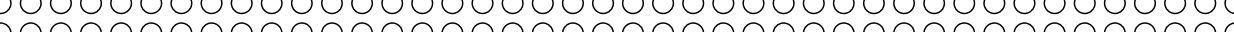
000000000000000000000000000000000000000000 000000000000000000000000000000000000000000 000000000000000000000000000000000000000000 000000000000000000000000000000000000000000

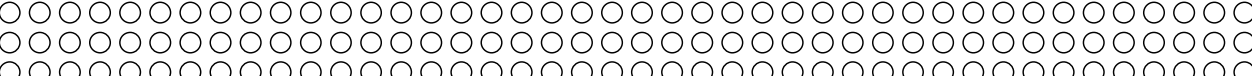
000000000000000000000000000000000000000000 000000000000000000000000000000000000000000

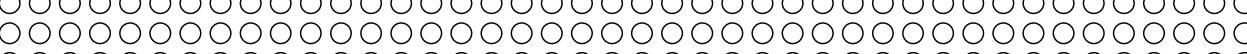
OOOOOOOOOOOOOOOOOOOOOOOOOOOOOOOOOOOOOOOOOOOOOO 
00000000000000000000000000000000000000 000000000000000000000000000000000000000000 000000000000000000000000000000000000000000 O०0000000000000000000000000000000000000000 000000000000000000000000000000000000000000 000000000000000000000000000000000000000000 (1) 000000000000000000000000000000000000000000 000000000000000000000000000000000000000000 $\begin{array}{lll} & 0\end{array}$

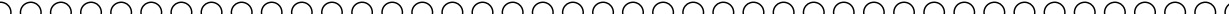
०००००००00000000000000000000000000000000000 000000000000000000

00000000000000000000000000000000000000 000000000000000000000000000000000000000000 ० 00000000000000000000000000000000000000000 000000000000000000000000000000000000000000

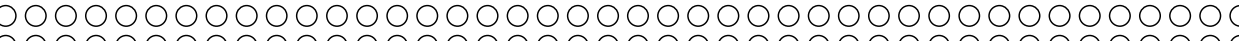

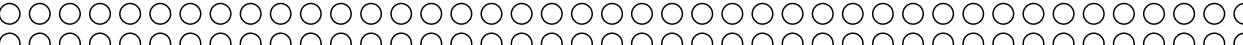
000000000000000000000000000000000000000000 0000000000000000000000000000000000000000 000000000000000000000000000000000000000000

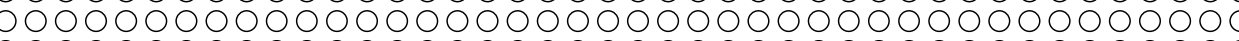

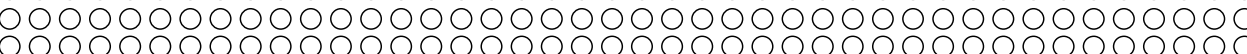
000000000000000000000000000000000000000000 00000000000000000000000000000000000

00000000000000000000000000000000000000

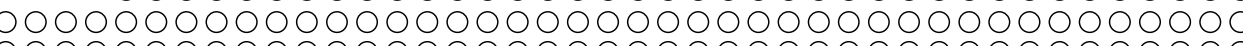
(1) 000000000000000000000000000000000000000000

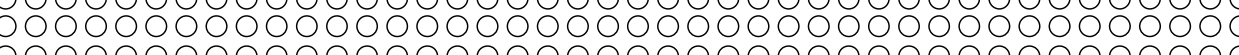

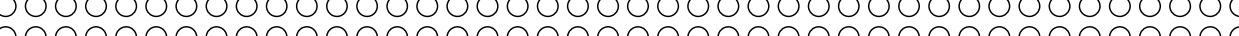

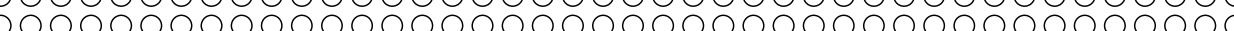
000000000000000000000000000000000000000000 , 00000000000000000000000000000000000000000 000000000000000000000000000000000000000000

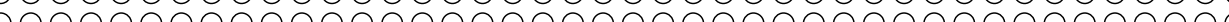
000000000000000000000000000000000000000000 000000000000000000000000000000000000000000 0000000000000000000000000

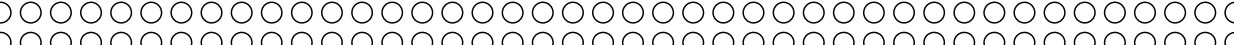

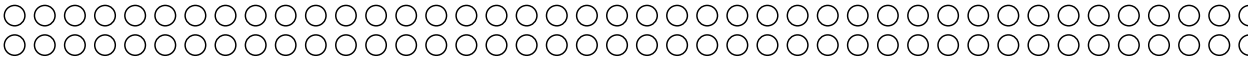
000000000000000000000000000000000000000000

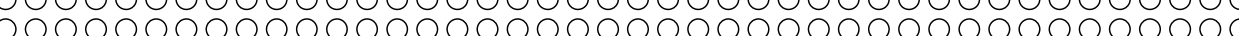
000000000000000000000000000000000000000 00000000000000000000000000000000000 
00000000000000000000000000000000000000 000000000000000000000000000000000000000000 000000000000000000000000000000000000000000 000000000000000000000000000000000000000000 000000000000000000000000000000000000000000 000000000000000000000000000000000000000000 000000000000000000000000000000000000000000 000000000000000000

00000000000000000000000000000000000000 000000000000000000000000000000000000000000 000000000000000000000000000000000000000000 000000000000000000000000000000000000000000 000000000000000000000000000000000000000000 000000000000000000000000000000000000000000 000000000000000000000000000000000000000000 00000000000000000000000000000000000

00000000000000000000000000000000000000 000000000000000000000000000000000000000000 000000000000000000000000000000000000000000 000000000000000000000000000000000000000000 000000000000000000000000000000000000000000 000000000000000000000000000000000000000000 000000000000000000000000000000000000000000 000000000000000000000000000000000000000000 000000000000000000000000

00000000000000000000000000000000000000 000000000000000000000000000000000000000000 000000000000000000000000000000000000000000 000000000000000000000000000000000000000000 00000000000000000000000000000000000 
00000000000000000000000000000000000000 000000000000000000000000000000000000000000 000000000000000000000000000000000000000000 000000000000000000000000000000000000000000 000000000000000000000000000000000000000000 000000000000000000000000000000000000000000 000000000000000000000000000000000000000000 000000000000000000

00000000000000000000000000000000000000 000000000000000000000000000000000000000000 000000000000000000000000000000000000000000 000000000000000000000000000000000000000000 000000000000000000000000000000000000000000 000000000000000000000000000000000000000000 000000000000000000000000000000000000000000 00000000000000000000000000000000000

00000000000000000000000000000000000000 000000000000000000000000000000000000000000 000000000000000000000000000000000000000000 000000000000000000000000000000000000000000 000000000000000000000000000000000000000000 000000000000000000000000000000000000000000 000000000000000000000000000000000000000000 000000000000000000000000000000000000000000 
00000000000000000000000000000000000000 000000000000000000000000000000000000000000 000000000000000000000000000000000000000000 000000000000000000000000000000000000000000 000000000000000000000000000000000000000000 000000000000000000000000000000000000000000 000000000000000000000000000000000000000000 000000000000000000

00000000000000000000000000000000000000 000000000000000000000000000000000000000000 000000000000000000000000000000000000000000 000000000000000000000000000000000000000000 000000000000000000000000000000000000000000 000000000000000000000000000000000000000000 000000000000000000000000000000000000000000 00000000000000000000000000000000000

00000000000000000000000000000000000000 00000000000000000000000000000000000000 
00000000000000000

00000000000000000000000000000000000000 000000000000000000000000000000000000000000 000000000000000000000000000000000000000000 000000000000000000000000000000000000000000 000000000000000000000000000000000000000000 000000000000000000000000000000000000000000 000000000000000000000000000000000000000000 000000000000000000

00000000000000000000000000000000000000 000000000000000000000000000000000000000000 
00000000000000000

00000000000000000000000000000000000000 000000000000000000000000000000000000000000 000000000000000000000000000000000000000000

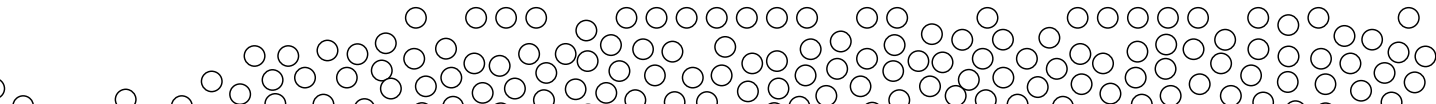

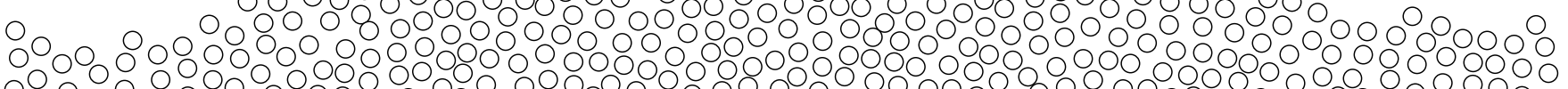

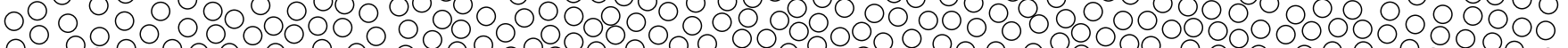

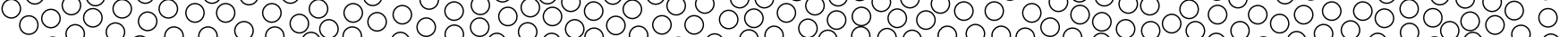

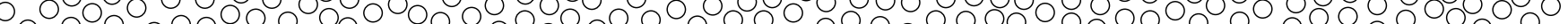

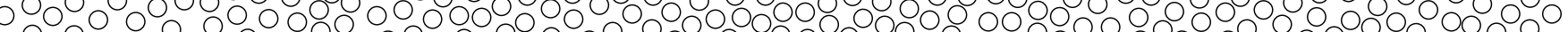

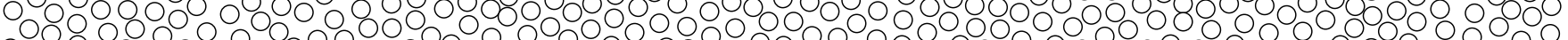



O trabalho, sem título, e por isso intitulado "ooo oooooo", foi publicado na revista que, na "Vistosa", substituiu o catálogo da exposição. Foi na "Vistosa" que se apresentou “1, 2, 3”, trabalho feito de chapas de eucatex perfuradas em padrões fechados e uniformes, sucedendo-se gradualmente, em sequência. Se em "1, 2, 3" a furação ingressava como dado concreto do repertório das vitrines comerciais, ela ao mesmo tempo funcionava como grade abstrata capaz de calibrar, ao deformar-se sutilmente, a percepção do espectador às propostas da exposição.

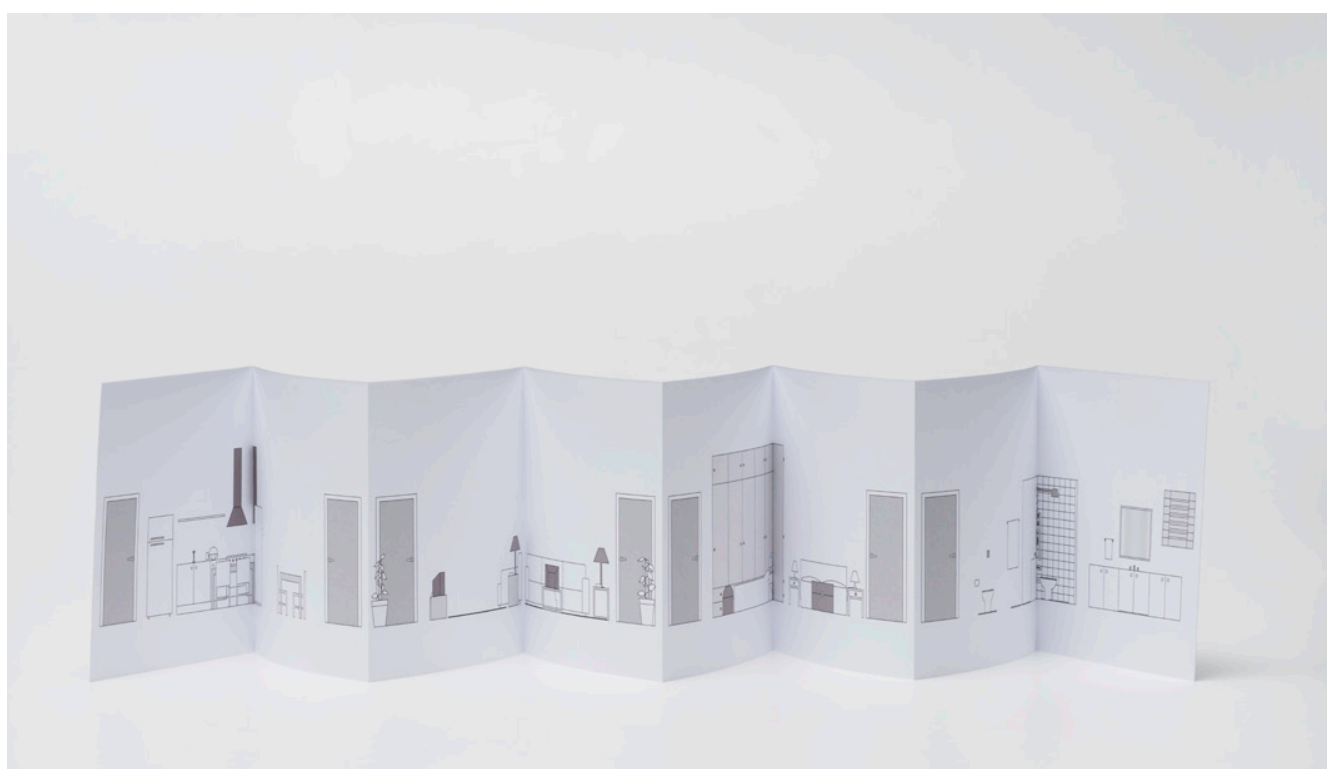

Com base num dos esquetes do vídeo "Programa”, apelidado de "Maquete", foi feito o ensaio gráfico intitulado "Apartamento". Primeiro publicado numa revista, recebeu depois a forma de um livro sanfonado. Em páginas duplas se representaram vistas complementares de quatro cômodos domésticos. As duas vistas de cada cômodo eram elevações frontais, sem perspectiva, e deslocavam-se 90 graus uma da outra, rebatendo os mesmos objetos. Assim, quando a publicação era manipulada, a posição relativa das páginas ajustava-se à posição relativa das elevações. Todos os objetos representados na publicação estavam presentes no esquete, com exceção das portas que, em “Apartamento", possibilitavam a passagem direta, sem silêncios ou interrupções, entre os cômodos contíguos.

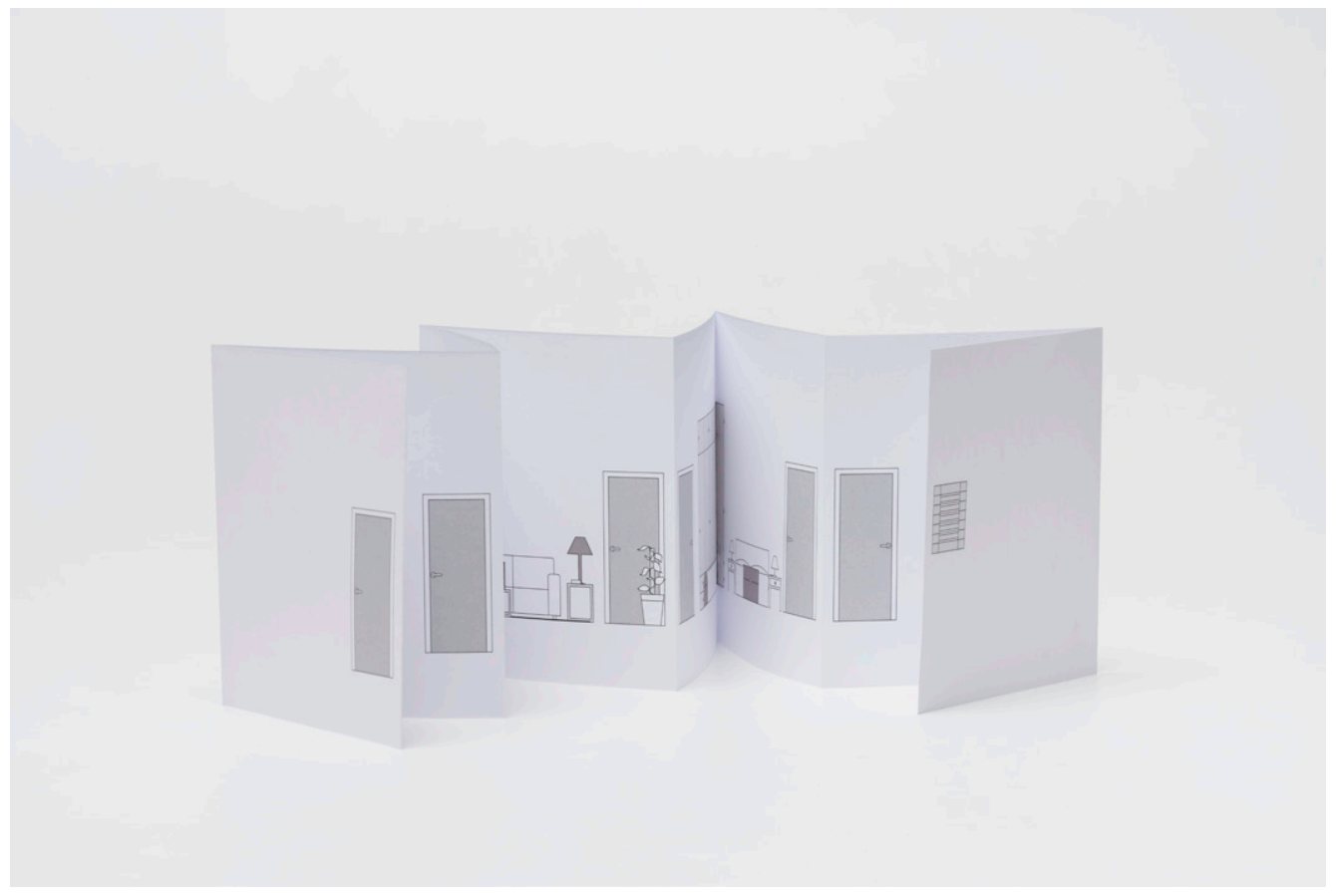


A câmera é fixa. Uma maquete redonda gira em velocidade constante diante dela. A maquete é feita de madeira e pintada de branco. Sobre o tampo redondo, travas perpendiculares de largura idêntica e altura variável configuram quatro espaços autônomos, separados por áreas vazadas. A tomada é frontal e o enquadramento fechado, de modo que jamais se vê mais de um desses espaços no mesmo quadro. Os espaços são cobertos por chapas horizontais que se fixam no topo das travas perpendiculares. Em cada um deles há miniaturas de móveis e objetos de um cômodo doméstico, feitas de madeira e pintadas de branco. A escala das miniaturas varia nos quatro espaços, proporcionalmente às alturas das coberturas.

Quando o primeiro cômodo entra em quadro, veem-se as miniaturas de uma geladeira, uma bancada com pia, um fogão, uma prateleira, uma mesa, quatro cadeiras. Ouvem-se os sons de um líquido despejado num copo, um exaustor ligado, talheres e louças manipulados, faca cortando legumes sobre uma tábua de madeira, água fervendo. Os sons, sobrepostos, são interrompidos subitamente quando o cômodo sai do quadro, dando vez, em silêncio, à área vazada.

Quando entra em quadro o segundo cômodo, veem-se as miniaturas de um sofá, uma mesinha lateral, uma luminária, uma mesa de centro, um televisor, um vaso de planta. Ouvem-se sons de canais de televisão trocados, móveis arrastados, um aspirador de pó, jornal sendo folheado, trânsito através da janela.

No terceiro cômodo há um padrão quadriculado nas paredes e as miniaturas de box com chuveiro, pia e gabinete, espelho, vaso sanitário. Os sons que o acompanham são de cortina de banho, chuveiro, barbeador elétrico, encanamento, caixa de descarga.

O quarto cômodo tem miniaturas de cama, poltrona, duas mesinhas, abajures, armário embutido e os sons de alarme, zíper, roupas de cama sacudidas,

ventilador de teto, relógio.
Na segunda volta da maquete diante da câmera, quando o primeiro cômodo entra em quadro, o conjunto de miniaturas se mantém em disposição idêntica, mas um dos sons é subtraído. Ouvem-se um exaustor ligado, talheres e louças manipulados, faca cortando legumes sobre tábua de madeira, água fervendo.

No segundo cômodo, mantidas as miniaturas, ouvem-se móveis arrastados, um aspirador de pó, jornal folheado, trânsito através da janela.

No terceiro cômodo ouvem-se chuveiro, barbeador, encanamento, caixa de descarga.

No quarto cômodo, zíper, roupas de cama sacudidas, ventilador de teto, relógio.

Na terceira volta, o primeiro cômodo retorna acompanhado dos sons de talheres e louças, faca cortando legumes, água fervendo. O segundo cômodo tem aspirador, jornal, trânsito. O terceiro, barbeador, encanamento, descarga. No quarto ouvem-se roupas de cama, ventilador, relógio.

A maquete dá cinco voltas completas diante da câmera fixa. A cada volta, subtrai-se o som mais marcante do conjunto, de maneira que o som remanescente ao final das cinco voltas é sempre o mais discreto. Na quinta volta ouvem-se um som de fervura no primeiro cômodo, trânsito entrando pela janela no segundo, água enchendo a caixa de descarga no terceiro e tictac de relógio no último. 

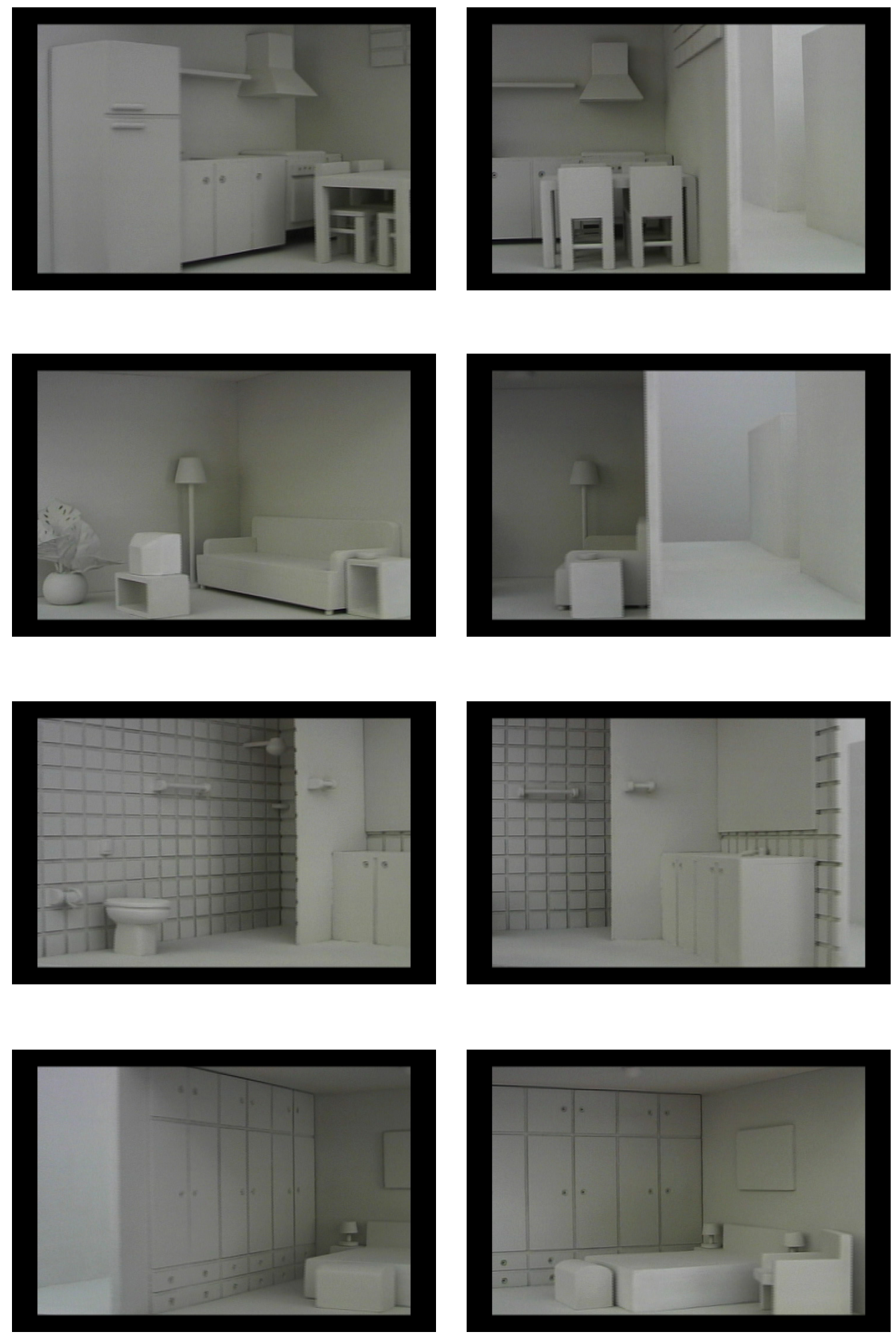

Nas primeiras voltas, embora se possam perceber mudanças no áudio, é difícil precisá-las. Os sons se amalgamam em massa e reivindicam a verossimilhança de sons ambiente. O procedimento só se torna evidente na última volta. É

então que a subtração devolve retrospectivamente, aos cinco sons do início, a autonomia de unidades desencadeadas.

Os espaços têm a mesma planta e a maquete gira em velocidade constante, o que faz com que o tempo em que cada um deles permanece em quadro seja idêntico e idêntica, portanto, seja a duração dos sons que os acompanham.

Como os cômodos originais têm tamanhos diferentes, alteram-se a escala dos objetos e os pés-direitos nos cômodos representados. O deslocamento circular da maquete, apresentando em espaços e tempos idênticos os quatro cômodos de tamanhos diferentes, tenta recalibrar sucessivamente a posição do espectador.

Na imagem ocorre apenas deslocamento. No som, apenas subtração. Associando esses procedimentos, o trabalho talvez destitua a relação entre imagem e som de suas clássicas conexões narrativas. Mas é preciso considerar que isso se dá à custa de silêncios e intervalos, e com a mediação encenada do ambiente doméstico. 

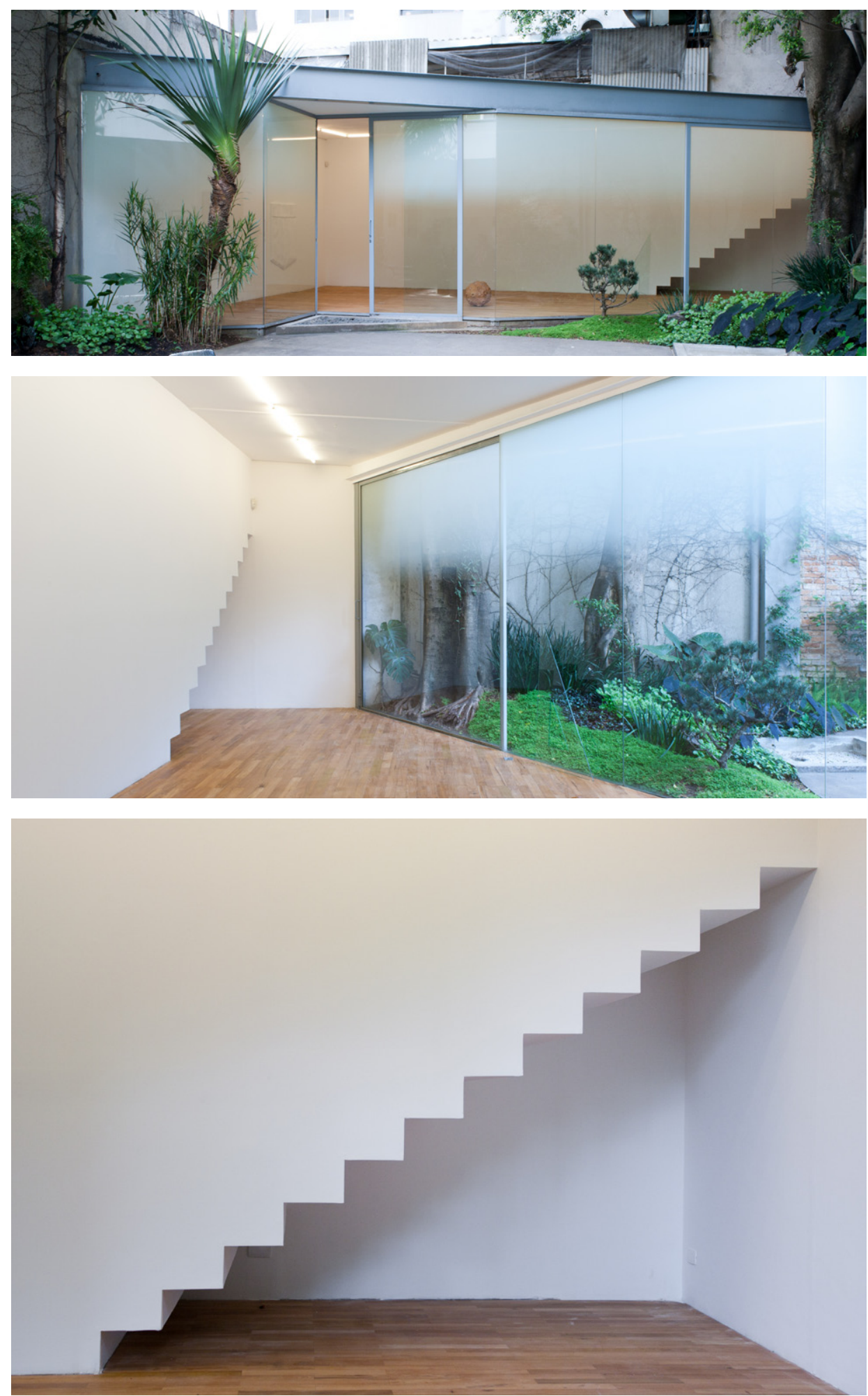

11

ESOTERISMO

\section{"EsCADA"}

Uma projeção negativa, como aqueles desenhos em que se delimita o objeto preenchendo-se apenas o entorno. Ou uma escada ao contrário, de pontacabeça. Ou o verso da escada, uma escada oculta atrás da parede.

A planta-baixa da sala é quase triangular. Uma parede à esquerda, uma parede maior no fundo, uma parede bem menor à direita. Na frente, um pano de

vidro em diagonal, interrompido pelo dente ortogonal da entrada. Na parede do fundo, junto à parede da direita, o recorte quase triangular, as linhas ortogonais retas, a diagonal dentada.

Uma abertura que se estende em profundidade por mais de um metro, revelando parte da área isolada atrás da parede, sem deixar de isolar a parte que não revela. Um espaço de sinal trocado que se define por seu avesso. O avesso inacessível ao qual, entretanto, se agregam atributos, um elemento funcional, um trajeto de circulação, um andar superior a alcançar.

O imóvel da galeria antes ocupado por uma loja de roupas, área de provadores no fundo da sala, ontem isolada atrás da parede, hoje parcialmente exposta, amanhã encerrada mais uma vez, até o dia da reforma, em que seu pé-direito, ontem rebaixado, hoje duplicado em dois andares, será igualado ao do restante da sala. 
"INSÔNIA"

Uma lâmpada acesa. Não propriamente acesa. Sem iluminar o entorno, iluminando-se apenas a si mesma. Redundando. Instalada dentro da vitrine do marceneiro em frente, do outro lado da rua.

Um bulbo maior que o tamanho padrão, instalado num soquete instalado no teto baixo da vitrine do marceneiro. Preenchido com um líquido opaco esbranquiçado que, tendo recebido luz e estando agora no escuro, acende. Não propriamente. Brilha num verde amarelo. Sinaliza.

O líquido fosforescente pesa e engorda em gota a base do bulbo, os pigmentos se sedimentam. É noite. A marcenaria é pequena. No primeiro plano, pintados na vitrine, os serviços:Travaux de Menuiserie, Entretien d'Immeubles...

Do outro lado da rua a galeria, La Maudite, e a exposição, "Économie domestique", fechada. Do outro lado da rua a lâmpada, em silencioso gerúndio, funcionando.
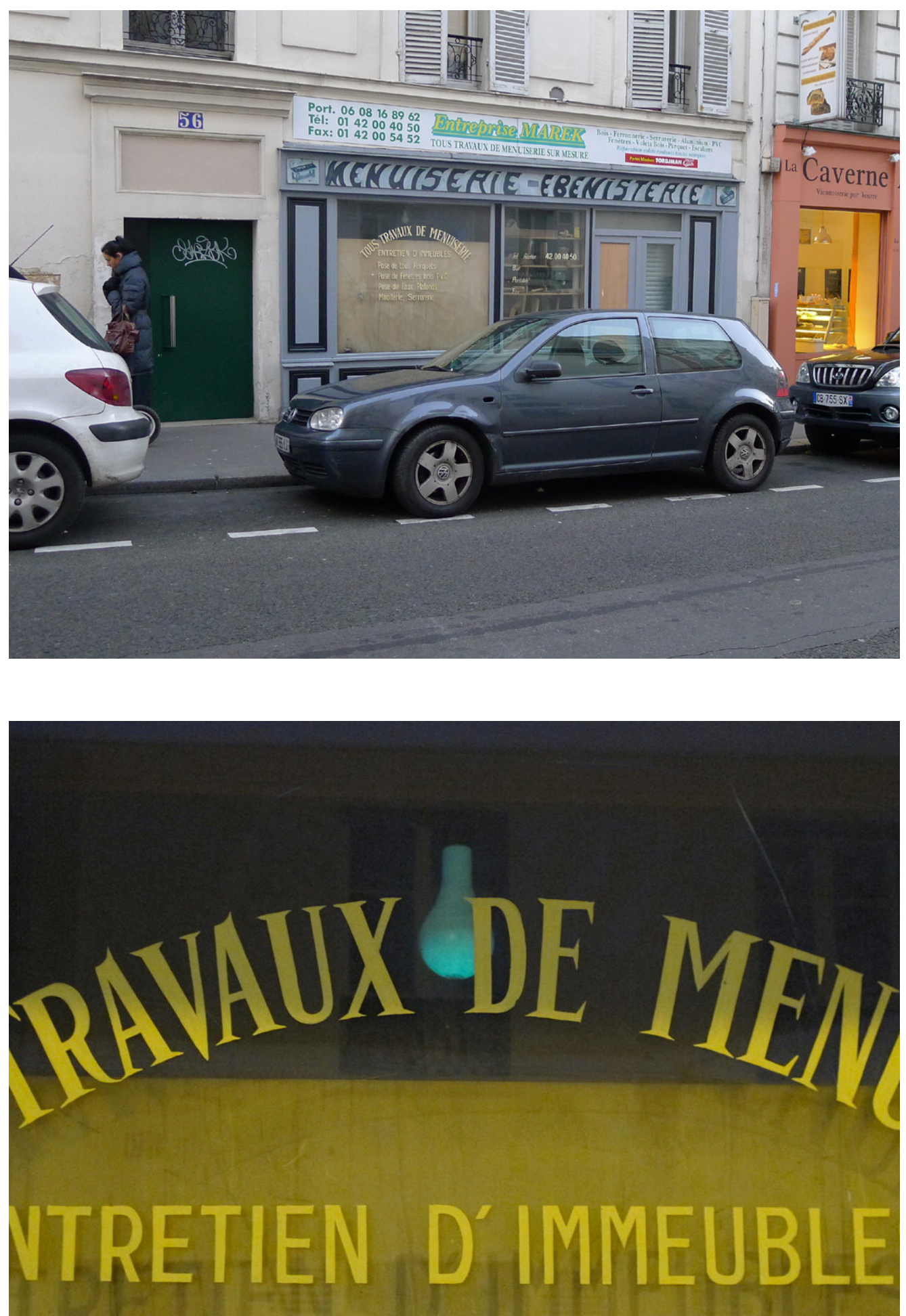


\section{SISTEMA DIGESTIVO}

O que se pode dizer numa língua morta?

Qualquer coisa que suporte ser ruminada, voltar do estômago à boca e da boca ao estômago. Qualquer coisa reflexiva, equívoca, remissiva, que pode se demorar em volutas porque sua origem se perdeu e sua pretensão de imediatidade já há muito se tornou obsoleta.

O que importa numa língua morta não são tanto os motivos que a fizeram morrer, mas os motivos pelos quais, mesmo morta, continua existindo.

Os "Desenhos de calígrafo" são uma série de desenhos a nanquim sobre papel pergaminata, falso pergaminho, encomendados a calígrafos profissionais. 


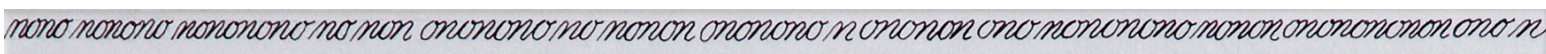

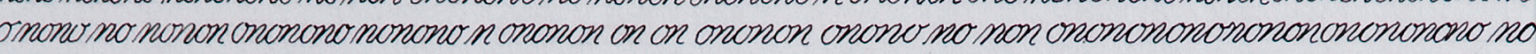

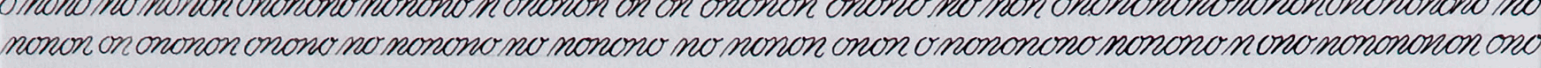

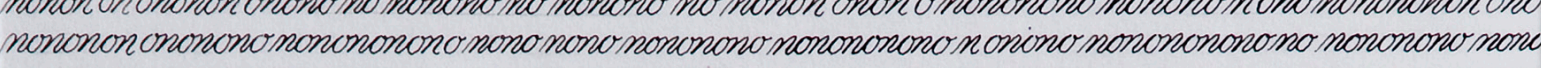

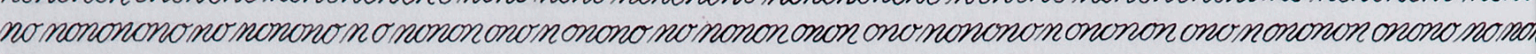

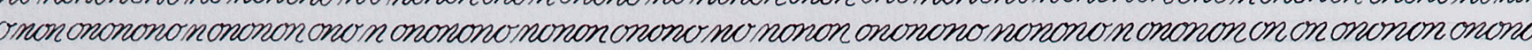

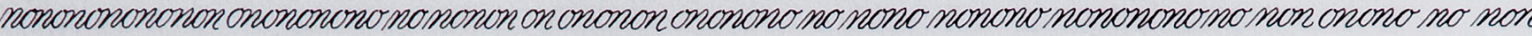

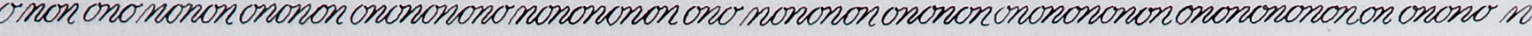

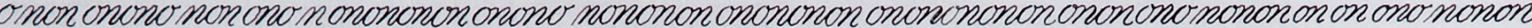

on on mononon ononon on ononononono nomononono...

elc. 
Lrio nonono nononono mo non ononono no nonon ononono, n ononon one nononono nonon on onononon one ne onono no nonon ononono, nonono nononon on on ononon onono no non ononononononon onononono no nonon on unonon. Onono no nonono no nonono no, nonon onon o nonon onononone, nonono mono monononon ono nononon ononono nonononon o nono nono nononono nonononono nonone nonononone. On ononono nonono no nonono no nonono m ononon ono.

Sononono nonon onon, ono nonone nononon ono n ononon onono no mon onenononononon onononone no nonon on unone, nononono ne nonono

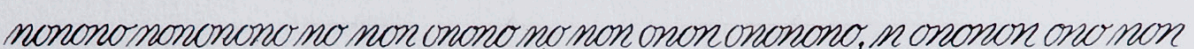
cnonono monon onono no nonen ononono nonono, n ononon on on ononon onono no non on o nonon ononon onon on on w nonenonon on o nonon on onon ononon ononononon ononononon.

Cnonononine nonononon on on on ononononon on one n onon, one nonono non ono n onononon, onono mononon onononon ononononon onon ono nonon on on ono nonon onone mon on onone. A ononono n ononon ononone nononow onon, no non ono nonon. So nononono, nononon o none

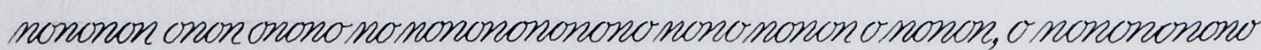
no nononon onomo nononono ne ono. N onono no nonon on onon onone, $n$ onchononon ononone, n ono non onone no mononionon onon ononono non onono non onono.

So nonorno nononon ono nonono nonon ononon on o nonononone.

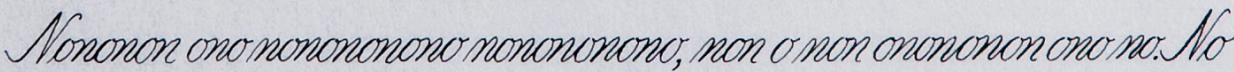
nono non ononon onone nono, monononono n on onone, mono non onono no nonononono nonon onononono non o mono nonononono.

\section{uma lingua morta}


foctrotider

molates pré-molares canino incisivos canino pré-molares molares. molartes pré malares canino incisivos canino prémolares molares. 
montanhamontanhamontanha. 
Prezado

Atetenciosamente

Cigante eo jabuti 
peixe

peixe

govian

peise.

priace

peisec

peiser

peisec

peise.

peixe

144 |

SISTEMA DIGESTIVO | 145 


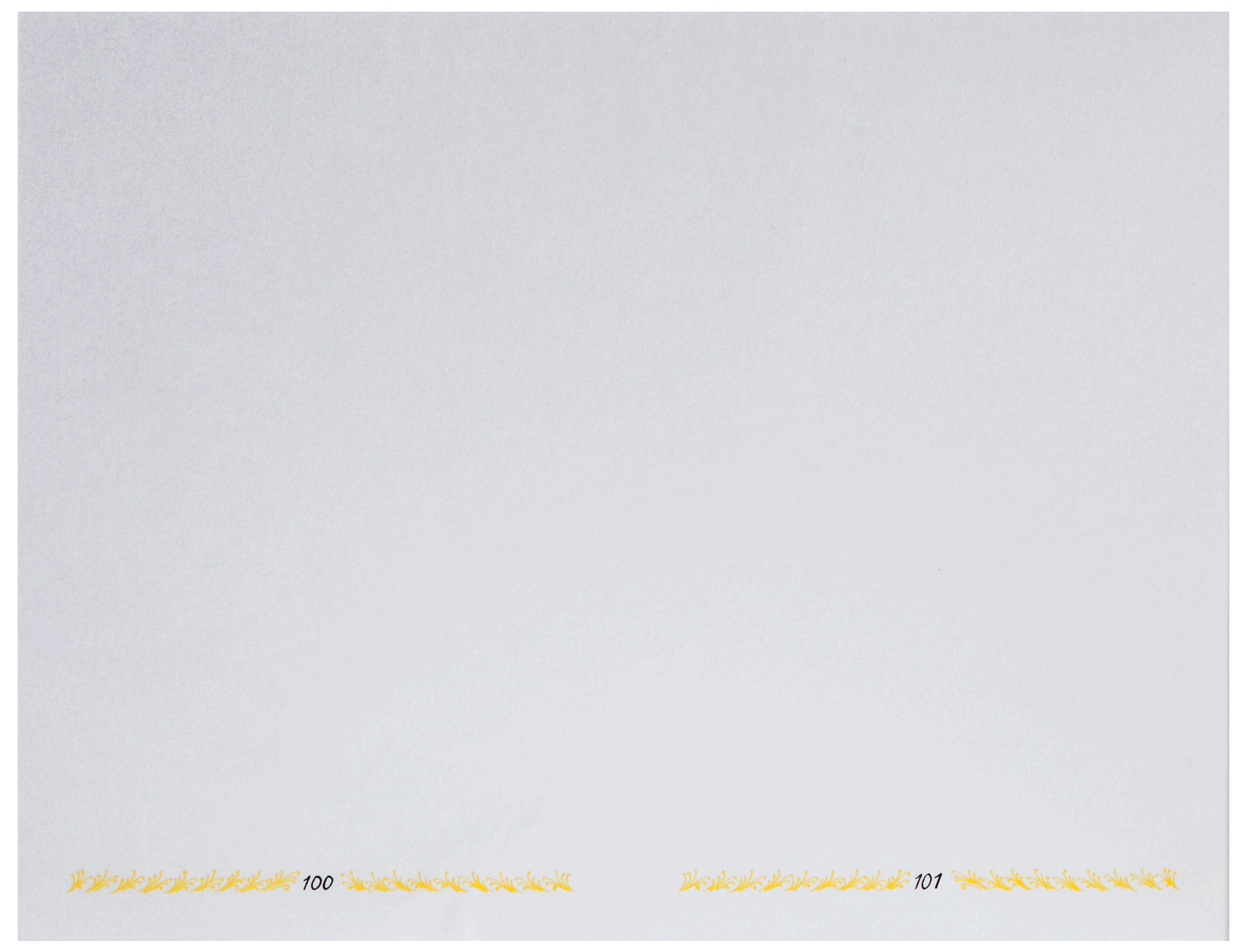


Assim, com o tanto de razão que resta ele

raciocina e raciocina mal. Pois estivesse a voz

falando não para ele mas para um outro então deveria ser daquele outro que está falando e não dele ou de um outro ainda. Uma vez que fala na segunda pessoa. Não estivesse falando dele para quem está falando mas de um outro não falaria na segunda pessoa mas na terceira. (Samuel Beckett, Companhia.)

O objeto desta tese são meus trabalhos de arte. Não todos os que realizei, mas alguns deles, reunidos em grupos, segundo critérios variados. Cada grupo de trabalhos constitui um capítulo da tese.

Os critérios em que se baseiam os agrupamentos são, em geral, de analogia: elementos comuns, simétricos ou proporcionais nos trabalhos; procedimentos comuns, confluentes ou paralelos; correspondências formais; relações similares com referentes; referentes comuns. Esses critérios, entretanto, não são dados a priori: só se constituem nas soluções formais dos capítulos. São identidades reversíveis e provisórias, formalizadas, caso a caso, nos textos e nas imagens que os acompanham.

Recursos de tratamento da linguagem como repetições, reiterações, paralelismos, inversões, interrupções aparecem nos capítulos. Feita a devida mediação, eles se relacionam às operações dos trabalhos. As imagens são fotografias, desenhos e representações gráficas e ingressam com estatutos variados, ora reiterando as matérias do texto, ora apondo, a elas, suas próprias; 
ora reivindicando autoridade documental, ora a autonomia de ensaios visuais. Os títulos dos capítulos, conferidos a posteriori, circunscrevem esses movimentos formais num campo semântico, sem pretender traduzi-los.

A abordagem dos trabalhos é, na maioria dos casos, descritiva. Há um caráter especulativo, entretanto, que se manifesta no interior mesmo da descrição, por meio dos aspectos eleitos na apresentação de cada trabalho, da extensão que se confere à exposição de cada um desses aspectos, da sua ordenação, dos aspectos negligenciados e, sobretudo, do modo como se faz a passagem entre os diferentes trabalhos: sem conexões explicativas, diretamente, por acareação.

Não há necessidade ou suficiência na relação entre os capítulos. Os mesmos trabalhos são tratados em vários deles. Não há um planejamento geral. Sigo associações sugeridas durante o processo, coordenando os grupos, sem subordiná-los um ao outro, ou conjugá-los numa armação abstrata Os capítulos, com seu critério de agrupamento particular, com seu arranjo formal particular, são textos autônomos, mas se somam e se informam sucessivamente, em vinculações pontuais.

O texto desta tese toma o seu objeto, meus trabalhos, do mesmo modo como meus trabalhos, antes, tomaram os seus objetos: sem acrescentar-lhes prefixos ou sufixos, produzir conhecimento aplicado ou derivado; apropriando-se mimeticamente de seus processos de formalização e testando, no limite, o próprio estatuto, ou seja, a capacidade de se diferenciar deles.

Inquirir sem interpretar e alinhar-se sem aderir. Como ocorre com cada um dos meus trabalhos, cada um destes textos reivindica autonomia em relação aos seus objetos, mas ainda assim quer lhes fazer justiça. Como ocorre com cada um destes textos, cada um dos meus trabalhos reivindica autonomia em relação aos demais, mas ainda assim aposta numa inteligência do todo.

Descrever porque, na impossibilidade de apreender satisfatoriamente, pela linguagem, os objetos, ainda assim é possível lhes conceder uma segunda chance de espacialização. Acarear porque, na impossibilidade de explicar as relações entre os objetos, ainda assim é possível confrontá-los.
BIBLIOGRAFIA ANOTADA

Selecionei trechos e fiz anotações a respeito de alguns dos textos consultados, dos quais talvez possamos encontrar, a posteriori, reverberações neste trabalho.

ADORNO, Theodor. Anotações sobre Kafka. In: Prismas. Crítica cultural e sociedade. São Paulo: Ática, 2001. GB, 1973

. Arte engajada e arte autônoma. In: Notas de literatura. Rio de Janeiro:

Minima moralia. Londres: NLB, 1974.

. Museu Valéry Proust. In: Prismas. Crítica cultural e sociedade. São Paulo: Ática, 2001

Teoria estética. Lisboa: Edições 70, s/d.

"A forma (...) só é substancial quando não exerce nenhuma violência sobre o formado, e a partir dele emerge. Porém, o formado, o conteúdo, não são objetos exteriores à forma, mas impulsos miméticos arrastados para esse mundo das imagens que é a forma. (...) A forma, a qual é devida ao conteúdo, é em si mesma conteúdo sedimentado.” (p. 163166)

; HORKHEIMER, Max. Excurso I: Ulisses ou mito e esclarecimento. In: Dialética do esclarecimento. Rio de Janeiro: Jorge Zahar, 1985, p. 53-80. 
; MANN, Thomas. Correspondencia 1943-1955. Buenos Aires: Fondo de Cultura Económica, 2006.

“... neste instante quase me parece que através desse tipo de exatidão se poderia expiar parte do pecado que é um aspecto de qualquer ficção artística; como se esta se curasse de si mesma através do remédio da fantasia exata." (Carta de Adorno a Mann, 18/01/1954, p. 141)

ALIGUIERO e Boetti. Milão: Charta, 2004.

BARIKIN, Amelia. Parallel presents. The art of Pierre Huyghe. Cambridge, Massachusetts: The MIT Press, 2012.

BARTHES, Roland. Aula. São Paulo: Cultrix, 1997.

Impedidos de escapar à "autoridade da asserção" e ao "gregarismo da repetição", resta-nos trapacear a linguagem, visando a "responsabilidade da forma”. A essa trapaça Barthes chama de literatura. "Porque ela encena a linguagem, em vez de, simplesmente, utilizá-la, a literatura engrena o saber no rolamento da reflexividade infinita.” (p. 19)

. Mitologias. Rio de Janeiro: Difel, 2003.

BECKETT, Samuel. Companhia. In: Companhia e outros textos. São Paulo: Globo, 2012.

"Pode o criador rastejante rastejando no mesmo escuro criado que a sua criatura criar enquanto rasteja? Uma das perguntas que ele se fez enquanto entre dois rastejamentos deitou-se. E se a resposta óbvia não estivesse longe buscar a mais útil era outro problema.” (p. 56)

. Dias felizes. São Paulo: Cosac Naify, 2010.

. Proust. São Paulo: Cosac Naify, 2003.

BENETTI, Liliane. Ângulos de uma caminhada lenta: exercícios de contenção, reiteração e saturação na obra de Bruce Nauman. São Paulo, 2013. Tese de Doutorado. Escola de Comunicações e Artes da Universidade de São Paulo.

BENJAMIN, Walter. A crise do romance. In: Magia e técnica, arte e política. Obras escolhidas. vol. 1. São Paulo: Brasiliense, 2000.

. A imagem de Proust. In: Magia e técnica, arte e política. Obras escolhidas. vol. 1. São Paulo: Brasiliense, 2000.

. Experiência e pobreza. In: Magia e técnica, arte e política. Obras escolhidas. vol. 1. São Paulo: Brasiliense, 2000.

. Franz Kafka. A propósito do décimo aniversário de sua morte. In: Magia e Técnica, arte e política. Obras escolhidas. vol. 1. São Paulo: Brasiliense, 2000.

. O narrador. Considerações sobre a obra de Nikolai Leskov. In: Magia e técnica, arte e política. Obras escolhidas. vol. 1. São Paulo: Brasiliense, 2000.

. Sobre o conceito de história. In: Magia e técnica, arte e política. Obras escolhidas. vol. 1. São Paulo: Brasiliense, 2000.

BUCHLOH, B. Marcel Broodthaers: open letters, industrial poems. In: Neoavantgarde and culture industry. Cambridge, MA: MIT Press, 2000.

CALDAS, Waltercio. Manual da ciência popular. São Paulo: Cosac Naify, 2007.

CANDIDO, Antonio. A literatura e a formação do homem. In: Textos de intervenção. DANTAS, Vinicius, (ed.). São Paulo: Duas cidades; 34 Letras, 2002.

DEMAND, Thomas. Executive. From poll to presidency. Colônia: Walter König, 2012.

DOSTOIÉVSKI, Fiódor. O idiota. São Paulo: Ed. 34, 2002.

O eterno marido. São Paulo: Ed. 34, 2003.

DUCHAMP, M. Marcel Duchamp - Engenheiro do tempo perdido, entrevistas com Pierre Cabanne. Lisboa: Assírio e Alvim, 1990. 
ECKLUND, D. The pictures generation: 1974-1984. Nova York: The Metropolitan Museum of Art; Yale University Press, 2009.

EISENSTEIN, Sergei. Montagem de atrações. In: XAVIER, I. (Org.). Experiência do cinema. Rio de Janeiro: Graal; Embrafilmes, 1983.

FAULKNER, William. Enquanto agonizo. Porto Alegre: L\&PM, 2010.

. O som e a fúria. São Paulo: Cosac Naify, 2004.

Passagens da história de uma família no sul dos EUA expostas em primeira pessoa, sem elaboração, sem causalidade, sem hierarquia, sem mediação, por diferentes personagens, entre eles um deficiente mental. As transições de voz não são anunciadas, assim como os saltos no espaço e no tempo. À opacidade da linguagem corresponde a brutalidade do enredo. O leitor cerca os fatos, tenta organizá-los.

FLAUBERT, Gustave. Bouvard e Pécuchet. São Paulo: Estação Liberdade, 2007.

Três contos. São Paulo: Cosac Naify, 2004.

Um tríptico de unidades autônomas e conexões sutis. O primeiro conto é um retrato, em que a narrativa, quase imóvel, incorpora os atributos da personagem. O segundo se apropria do esquema da hagiografia. A fatalidade e a violência na história de São Julião, em sucessão rápida de ações, se naturalizam. O terceiro é uma narrativa bíblica, fatos manipulados, encenada, que termina numa cabeça decepada: "Como era muito pesada, carregavam-na alternadamente.”

. Dicionário das idéias feitas. Lisboa: Editorial Estampa, 1974.

FLECK, Robert; SÖNTGEN, Beate; DANTO, Arthur C. Peter Fischli - David Weiss. Londres: Phaidon, 2005.

FOUCAULT, Michel. As palavras e as coisas. São Paulo: Martins Fontes, 2000.
"A ordem é ao mesmo tempo aquilo que se oferece nas coisas como a sua lei interior, a rede secreta segundo a qual elas se olham de algum modo umas às outras e aquilo que só existe através do crivo de um olhar, de uma atenção, de uma linguagem.” (p. XVI)

. Isto não é um cachimbo. Rio de Janeiro: Paz e Terra, 1988.

GIDE, André. Diário dos moedeiros falsos. São Paulo: Estação Liberdade, 2009.

Anotações de Gide durante a criação de Moedeiros falsos, romance no qual um dos personagens, um escritor, mantém um diário com anotações sobre o livro que está escrevendo, Moedeiros falsos. Desenvolvimento dos personagens, construção do enredo e questões de método, como: "Sou pelo paradoxo de Wilde: a natureza imita a arte; e a regra do artista deve ser não limitar-se às propostas da natureza, mas não lhe propor nada que ela não possa, que ela não deva logo imitar." (p. 39) Ou, mais adiante: "Pude questionar se talvez essa disposição de espírito (...) não se torna menos perigosa depois que é catalogada e, como acontece que só se dá um nome àquilo de que a gente se separa, se essa fórmula já não pressagia uma partida"(p. 100). Finalmente: "Este [livro] se terminará bruscamente, não por esgotamento do assunto, que deve dar a impressão de ser inesgotável, mas, ao contrário, por seu alargamento e por uma espécie de evasão de seu contorno. Ele não deve se fechar, mas espalhar-se, desfazer-se..." (p. 106)

. Moedeiros falsos. São Paulo: Estação Liberdade, 2009.

Os porões do Vaticano. São Paulo: Estação Liberdade, 2009.

GODFREY, Mark; OBRIST, Hans-Ulrich; GILLICK, Liam. Anri Sala. Londres: Phaidon, 2006.

GÓGOL, N. O capote e outras histórias. São Paulo: 34 Letras, 2010. 
GÓRKI, M. Ganhando o meu pão. São Paulo: Cosac Naify, 2007.

. Infância. São Paulo: Cosac Naify, 2007.

Minhas universidades. São Paulo: Cosac Naify, 2007.

GÖRNER, Klaus. Jack Goldstein. Catálogo de exposição. Colônia: MMK; König Verlag, 2009.

GUNNING, Tom. The cinema of attractions: early film, its spectator, and the avant-garde. Wide angle, v. VIII, n. 3-4, Londres, 1986.

HAMON, P. O que é uma descrição. In: Categorias da narrativa. Lisboa: Vega, 1991.

HUYSMANS, J.K. Às avessas. São Paulo: Companhia das Letras, 1987.

IRAN do Espírito Santo - uma visão geral. São Paulo: Pinacoteca do Estado de São Paulo, 2007.

JÜNGER, Ernest. Nos penhascos de mármore. São Paulo: Cosac Naify, 2008.

KAFKA, Franz. O castelo. São Paulo: Companhia das Letras, 2000. . Um artista da fome/ A construção. São Paulo: Companhia das Letras, 1998.

KAISER, Philip (Ed.). Jack Goldstein x 10,000. Nova York: Prestal; Orange County Museum of Art, 2012.

KOOLHAS, Rem. NovaYork delirante. São Paulo: Cosac Naify, 2008.

KOSZTOLÁNYI, Dezsö. O tradutor cleptomaníaco e outras histórias de Kornél Esti. Rio de Janeiro: 34 Letras, 1996.

KRAUSS, Rosalind. A voyage on the North Sea. Londres: Thames and Hudson, 1999.

LESKOV, Nicolai. Lady Macbeth do distrito de Mtzensk. São Paulo: 34 Letras, 2009.

MACHADO, Dyonelio. Os ratos. São Paulo: Planeta do Brasil, 2004.
MACHADO DE ASSIS. Memórias póstumas de Brás Cubas. Rio de Janeiro: Garnier, s/d.

MAK, Barbara-Brigitte (Ed.). Carsten Höller 2001-2010 184 objects, experiments, events. Ostfildern-Ruit: Hatje Cantz, 2010.

MANN, Thomas. A lei. In: Duas novelas: A lei e A enganada. São Paulo: Mandarim, 2001.

"Este é um capítulo obscuro, que só pode ser escrito com meias e nebulosas palavras", mas as palavras são inteiras e nítidas. Reconta-se, em 1944, a história de Moisés. Numa narrativa fluida, dão-se versões profanas das dez pragas lançadas sobre o Egito e do recesso do mar, do maná e da sobrevivência de Moisés sob as lavas do monte Sinai. A ironia esclarecida, entretanto, não desvenda tudo: fica preservado o mistério da espiritualidade encarnada, autoritária, violenta e implacável de Moisés. 2000 . Confissões do impostor Felix Krull. Rio de Janeiro: Nova Fronteira,

O eleito. São Paulo: Mandarim, 2000.

MATZNER, Florian (Ed.). Tobias Rehberger 005-000 [pocket dictionary]. Ostfildern-Ruit: Hatje Cantz, 2001.

MORGAN, Jessica; JONES, Leslie. John Baldessari - pure beauty. Los Angeles: LACMA, 2009.

NAUMAN, B. Please pay attention please: Bruce Nauman's words. KRAYNAK, J. (Ed.). Cambridge, Massachusetts: MIT Press, 2005.

ONDÁK, Roman (Org.). Roman Ondák - guide. Colônia: Walter König; Milão: Mousse Publishing, 2010.

PEREC, Georges. A coleção particular. São Paulo: Cosac Naify, 2005. . A vida modo de usar. São Paulo: Companhia das Letras, 2009. 
Um único objeto, convertido em quase-personagem, organiza um conjunto heterogêneo de narrativas e descrições e empresta sua forma à forma do texto: o quebra-cabeças, não o fabricado à máquina, em que "o corte não atende a requisito nenhum”, mas aquele em que cada ilusão, cada lance de astúcia, cada questão posta ao jogador foi cuidadosamente planejada. Descrições se ramificam, ampliam e desdobram exponencialmente o espaço esquadrinhado de um prédio de apartamentos, cujos ocupantes se sucedem no intervalo de um século.

. As coisas. São Paulo: Companhia das Letras, 2012.

W ou a memória da infância. São Paulo: Companhia das Letras, 1995.

PÉREZ-BARREIRO, Gabriel. Jorge Macchi: exposição monográfica. Porto Alegre: Fundação Bienal do Mercossul, 2007.

PIRANDELLO, Luigi. Novelas para um ano: Dona Mimma. São Paulo: Berlendis \& Vertecchia, 2002

Realismo: "Eis porque os mortos vêm à minha casa, agora.

E comigo - pobres pensionistas da memória - refletem com amargura sobre as vãs ilusões da vida, de que se desiludiram totalmente, e de que não posso ainda me desiludir totalmente eu também, ainda que como eles as reconheça vãs." (Os pensionistas da memória, p. 173)

2000 .

Novelas para um ano: $O$ velho Deus. São Paulo: Berlendis \& Vertecchia,

Novelas para um ano: Uma jornada. São Paulo: Berlendis \& Vertecchia, 2006.

. O falecido Mattia Pascal. São Paulo: Nova Alexandria, 2007.

. Seis personagens à procura de um autor. São Paulo: Peixoto Neto, 2004.

PROUST, Marcel. A fugitiva. São Paulo: Globo, 2000.
À sombra das raparigas em flor. São Paulo: Globo, 1999.

A prisioneira. São Paulo: Globo, 1998

. No caminho de Swan. São Paulo: Globo, 1999.

O caminho de Guermantes. São Paulo: Globo, 1996.

O tempo redescoberto. São Paulo: Globo, 1998.

Sodoma e Gomorra. São Paulo: Globo, 1998.

QUENEAU, Raymond. Zazie no metrô. São Paulo: Cosac Naify, 2009.

O tempo é linear e a leitura é rápida. Mas as idades e os gêneros dos personagens são duplicados, seus papéis são reversíveis. Informações são desmentidas, ou entram em espirais tautológicas. "Falar, falar, vocês só sabem fazer isso": só isso fala o papagaio. A tudo se aplica o escárnio da protagonista. A narrativa progride e ganha tensão. Zazie dorme no momento do clímax.

SALZSTEIN, Sônia. Livros, superfícies rolantes. In: WALTERCIO Caldas Livros. Catálogo de exposição. São Paulo: Pinacoteca do Estado; Porto Alegre: MARGS, 2002.

. The Many Masquerades of Antonio Dias. In: HERZOG, Hans-

Michael (Org.). Antonio Dias / Anywhere is my Land. Zürich; Ostfildern: Daros Latinamerica AG; Hatje Cantz Verlag, 2009, p. 12-67.

.Where?. In: BRETT, Guy (Org.). Cildo Meireles. Londres: Tate Publishing, 2008, p. 152-157.

Sobre os trabalhos "Através" e "Eureka/ Blindhotland", de Cildo Meireles: "Mas talvez o que aí esteja em questão seja justo o inapreensível, o inumano que reside em deparar-se com algo clarividente em relação ao qual, não obstante, todo esforço de descrição é expletivo e impotente. A propósito: será que esses trabalhos solicitam interpretação? Não parece 
mais realista tão-somente acompanhar suas operações,

descrevendo-as e buscando compreendê-las? Ou apreender sua 'lei de formação', que aliás será sempre diversa em cada trabalho?"

SARRAZAC, Jean Pierre (Org.). Léxico do drama moderno e contemporâneo. São Paulo: Cosac Naify, 2011.

SARTRE, J. P. As palavras. Rio de Janeiro: Nova Fronteira, 2000.

SCHNITZLER, Arthur. Breve romance do sonho. São Paulo: Companhia das Letras, 2008.

SCHWARZ, Roberto. Um mestre na periferia do capitalismo/ Machado de Assis. São Paulo: Duas Cidades; 34 Letras, 2000.

STEIN, Gertrude. Três vidas. São Paulo: Cosac Naify, 2008.

STENDHAL. A cartuxa de Parma. São Paulo: Globo, 2004.

O vermelho e o negro. São Paulo: Cosac Naify, 2003.

SZONDI, P. Teoria do drama burguês. São Paulo: Cosac Naify, 2004.

TAMARO, Angela Harumi. A descrição na literatura e no cinema. Pro-posições, vol. 10, n. 1, março de 1999.

TOLSTÓI, Liev. A morte de Ivan Ilitch. São Paulo: 34 Letras, 2006.

Ressurreição. São Paulo: Cosac Naify, 2010.

VIRGEN, Miguel González. Of games, the infinite and worlds: the work of Gabriel Orozco. Dublin: The Douglas Hyde Gallery; Merz, 2003.

VISCHER, T.; NAEF, H. JeffWall/ Catalogue raisonné 1978-2004. Basel:

Schaulager; Steidl, 2005.

WALTERCIO Caldas - Livros. Catálogo de exposição. São Paulo: Pinacoteca do Estado; Porto Alegre: MARGS, 2002.

WOOLF, Virginia. Orlando. Rio de Janeiro: Nova Fronteira, 2003.
O texto se apresenta como a biografia do personagem que lhe dá nome, embora a tarefa do biógrafo seja todo tempo ironizada. Não se contam fatos e descrevem espaços, mas contam-se pensamentos e descrevem-se, projetados em detalhes nas paisagens, "estados de espírito". O personagem nasce no século XVI e é acompanhado até os 36 anos, que completa em 1928. Um aristocrata sonhador, de sentimento puro, que muda de atividade, de interesse, de sexo, para permanecer sempre igual. Tratamento tanto mais rebuscado quanto mais indiferente e transitório o objeto tratado.

XAVIER, Ismail. O discurso cinematográfico: a opacidade e a transparência. São Paulo: Paz e Terra, 2005. 
FICHAS TÉCNICAS DOS TRABALHOS

“ooo oooooo”, 2008

ensaio gráfico

Revista, publicação independente produzida por ocasião da exposição "Vistosa", em parceria com João Loureiro

e Laura Huzak Andreato, com os recursos do Prêmio

Conexão Artes Visuais da FUNARTE.

\section{“1, 2, 3”, 2008}

eucatex perfurado, lâmpadas fluorescentes, instalação elétrica

aprox. 190 x 100 x $250 \mathrm{~cm}$

"Vistosa", exposição em parceria com João Loureiro e Laura Huzak Andreato, realizada em galpão alugado em São Paulo, Prêmio Conexão Artes Visuais, FUNARTE.

“Apartamento”, 2006-2013

livro sanfonado

$20 \times 16 \mathrm{~cm}$ (fechado)

Uma primeira versão desse trabalho foi publicada sob a forma de um ensaio gráfico na revista Ars, ano 4, n. 8, São Paulo, CAP-ECA-USP, 2006.

"Blocos Margeados", 2005

8 modelos de blocos de papel sulfite com 100 folhas impressas em offset e capa em cartolina colorida $31,3 \times 24,4 \times 1 \mathrm{~cm}$ cada bloco

"Desenho animado", individual na Galeria Ybakatu,

Curitiba, e "Além da Biblioteca", com curadoria de Ana Luiza Fonseca, Museu Lasar Segall, São Paulo, e Itochu Aoyama Art Square, Tóquio.
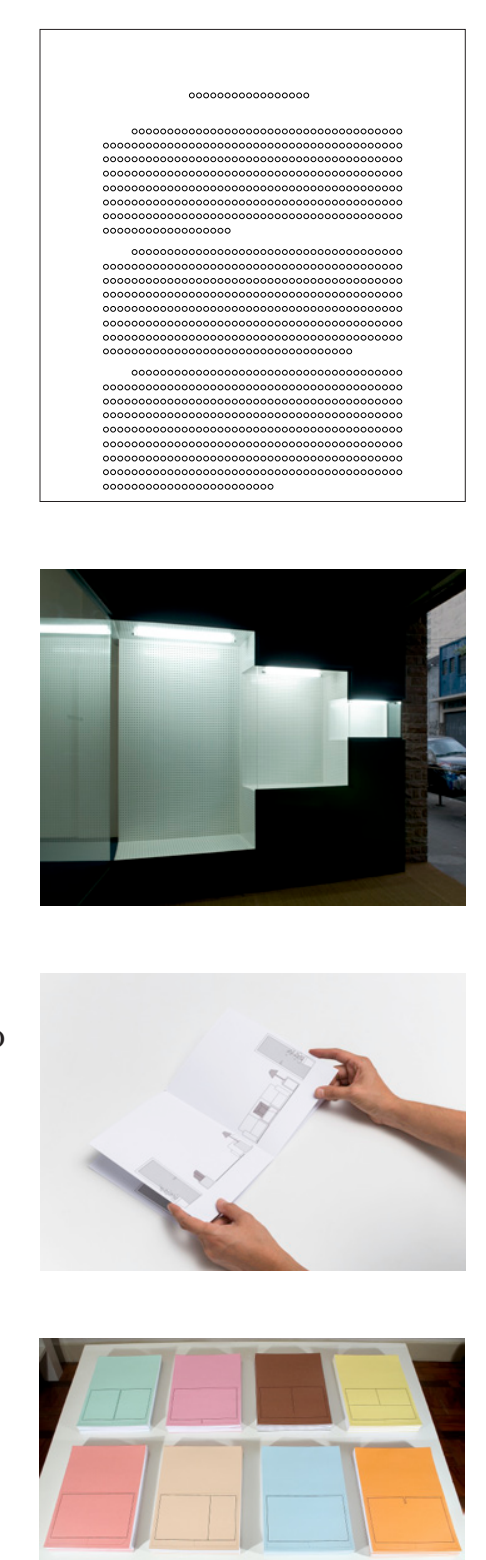

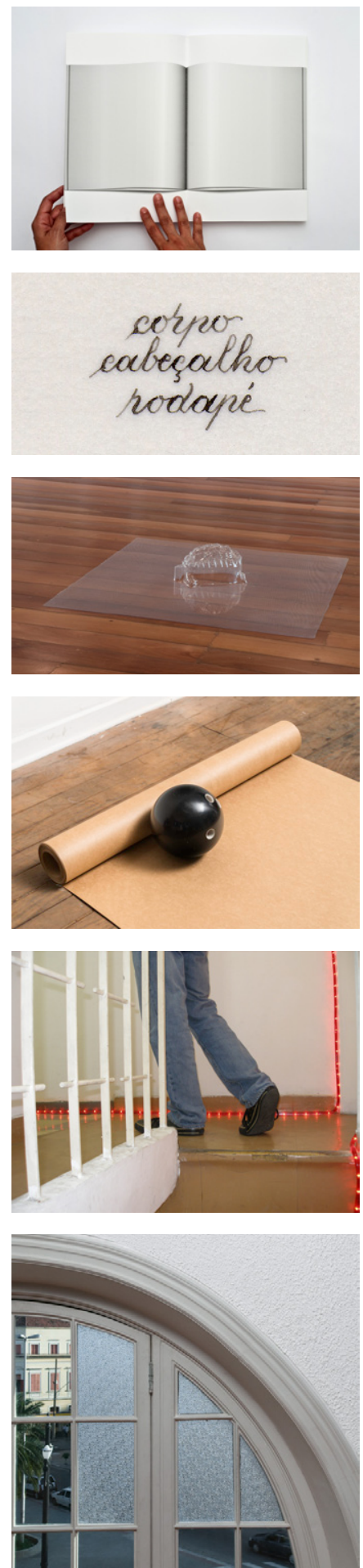

Brochura", 2013

ensaio gráfico

6 páginas

Publicado em OEI Magazine - On Paper, n. 62, 2013,

Estocolmo.

"Cambalhota", 2012

três desenhos a naquim sobre papel pergaminata,

executados por calígrafo profissional

27 x $21 \mathrm{~cm} \mathrm{cad}$

"Casco", 2009

PETG formado a vácuo

$25 \times 120 \times 120 \mathrm{~cm}$

“Ana Luiza Dias Batista - Programa”, curadoria de José

Augusto Ribeiro, Estação Pinacoteca, São Paulo, e

"Desenho animado", Galeria Ybakatu, Curitiba.

"Com efeito", 2013

bobina de papel kraft 300g e bola de boliche

$25 \times 350 \times 107 \mathrm{~cm}$

“Continuação”, 2008

mangueira luminosa e sequenciador

aprox. $50 \mathrm{~m}$ lineares

Galeria Cinesol, sobreloja do sebo Arquipélago,

Liberdade, São Paulo

Exposição organizada por Claudinei Roberto e Eurico Lopes.

"Crocante", 2009

chapisco de cimento sobre a parede e vidro fantasia

padrão granito

$250 \times 750 \mathrm{~cm}$

"Ana Luiza Dias Batista - Programa”, com curadoria de

José Augusto Ribeiro, Estação Pinacoteca, São Paulo.
"Desenhos de calígrafo", 2011

série de 12 desenhos a naquim sobre papel pergaminata, executados por calígrafos profissionais

27 x $21 \mathrm{~cm}$ cada

"Desenho animado", Galeria Ybakatu, Curitiba, e "20

anos do Programa de Exposições”, Centro Cultural São

Paulo, curadoria de José Augusto Ribeiro.

"Escada”, 2011

recorte na parede e acabamento em drywall

$240 \times 300 \times 120 \mathrm{~cm}$

"Área, alcance, domínio, esfera", Galeria Mendes Wood, São Paulo.

"Escalímetro", 2013

aço inox usinado e gravação a laser

$5 \times 0,5 \times 0,5 \mathrm{~cm}$

"Fotolitos: desembaçadores", 2010

fotolitos para impressão offset

$75 \times 113 \mathrm{~cm}$ cada

"Desenho animado", Galeria Ybakatu, Curitiba.

"Hipódromo", 2009

2 bobinas impressas

60 x $45 \mathrm{~cm} \varnothing$, aprox. $4 \mathrm{~km}$ de extensão cada

Trabalho comissionado pelo Centro Cultural São Paulo para a exposição "Sinais de Fumaça", com curadoria de Carla Zaccagnini e Fernanda Albuquerque.

"História”, 2012

porcelana decorada

$14 \times 26 \times 9 \mathrm{~cm}$
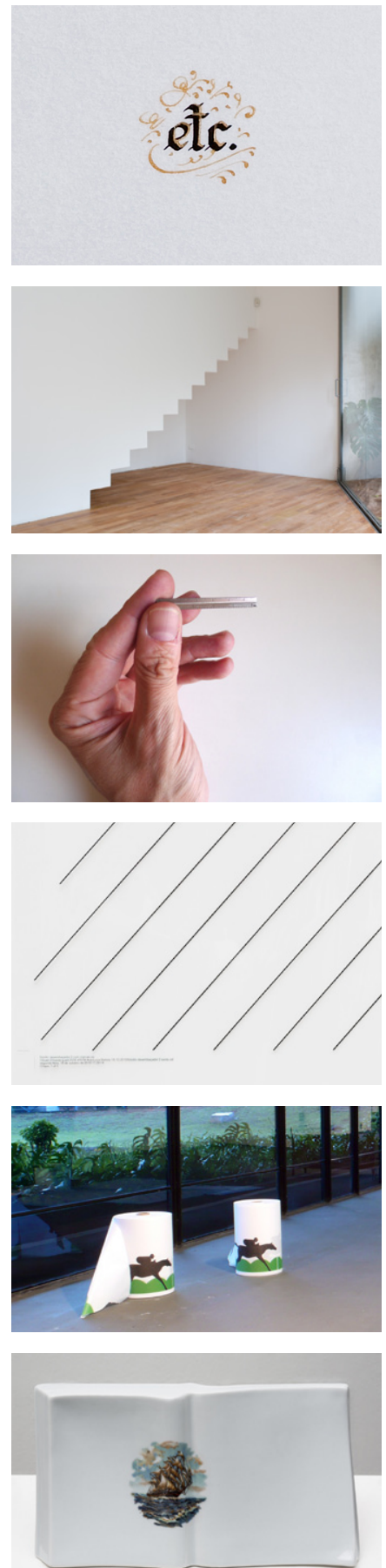

FICHAS TÉCNICAS | 165 


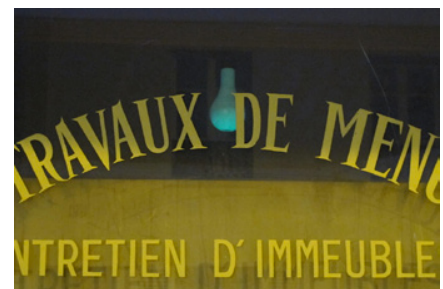

UTRETIEN D'IMMEUBLE
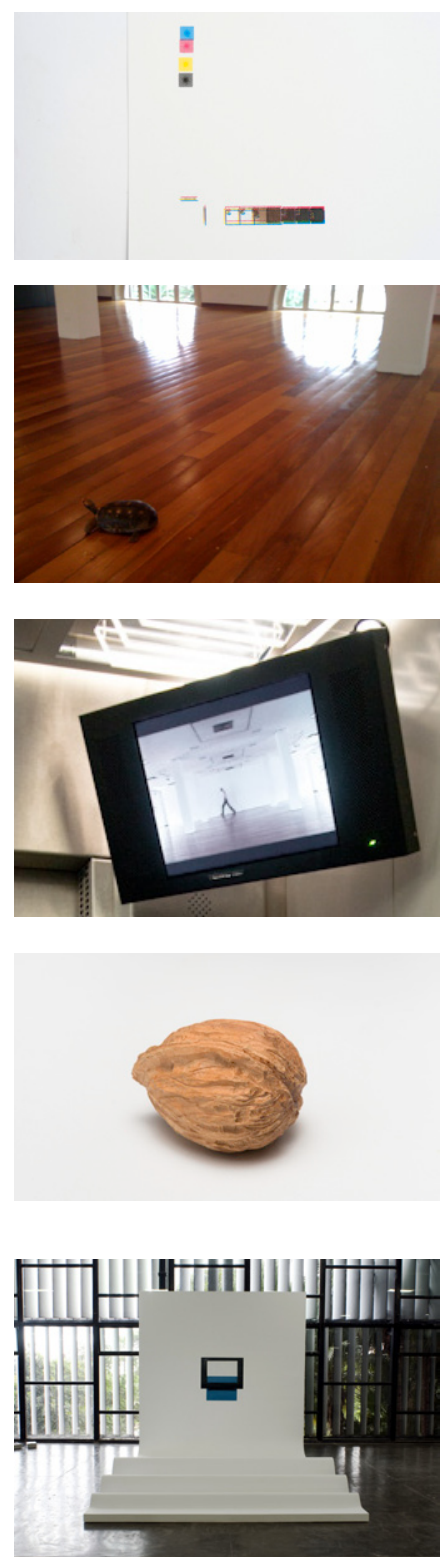

"Insônia", 2013

lâmpada, soquete e material fosforescente

"Économie domestique", exposição de Ana Luiza Dias Batista e João Loureiro, La Maudite, Paris.

"Moiré", 2013

serigrafia

tiragem de 20 exemplares

$45 \mathrm{x} 60 \mathrm{~cm}$

Apresentado na exposição “Économie domestique”, La Maudite, Paris.

"O Jabuti”, 2009

jabuti vivo solto no espaço expositivo no dia 12 de

dezembro de 2009

“Ana Luiza Dias Batista - Programa”, com curadoria de

José Augusto Ribeiro, Estação Pinacoteca, São Paulo.

"O gigante", 2009

vídeo em loop exibido em dois monitores instalados nos elevadores do museu e fotografia reproduzida no convite da exposição

“Ana Luiza Dias Batista - Programa”, com curadoria de José Augusto Ribeiro, Estação Pinacoteca, São Paulo.

"O que é, o que é?"

madeira entalhada

6 peças

aprox. $3 \times 2 \times 2 \mathrm{~cm}$ cada

"Painel mar", 2011

estrutura de madeira e pintura executada sob encomenda $300 \times 400$ x $400 \mathrm{~cm}$

Feira sp-arte 2011, projetos especiais.
"Parada", 2013

chapas de foam board recortadas a laser acondicionadas em caixas de acrílico

3 peças

$180 \times 128 \mathrm{~cm}$

"Programa”, 2007

vídeo em loop

$5 \mathrm{~min} 4 \mathrm{~s}$

Trabalho realizado durante o mestrado em artes visuais no Departamento de Artes Plásticas da Escola de

Comunicações e Artes da Universidade de São Paulo e

exibido em 2009 na exposição "Ana Luiza Dias Batista

- Programa”, com curadoria de José Augusto Ribeiro,

Estação Pinacoteca, São Paulo.

"Pulga", 2013

três lupas conta-fios

$18 \times 15 \times 15 \mathrm{~cm}$

"Queimada”, 2009

papel de parede impresso

aprox. 2,8 x $56 \mathrm{~m}$

pinturas: Nilton Bueno

fotografia: Isabella Matheus

Montagem: Renato Cury

“Ana Luiza Dias Batista - Programa”, com curadoria de José Augusto Ribeiro, Estação Pinacoteca, São Paulo.

"Rendas-potuguesas", 2007

cortina de renda, trilho, peça em aço-inox, xaxins com rendas-portuguesas, pratos de plástico

cortina: 340 × $2500 \mathrm{~cm}$

peça com plantas: $340 \times 120 \mathrm{~cm}$

"Ana Luiza Dias Batista - Programa Bolsa Pampulha", Museu de Arte da Pampulha, Belo Horizonte.
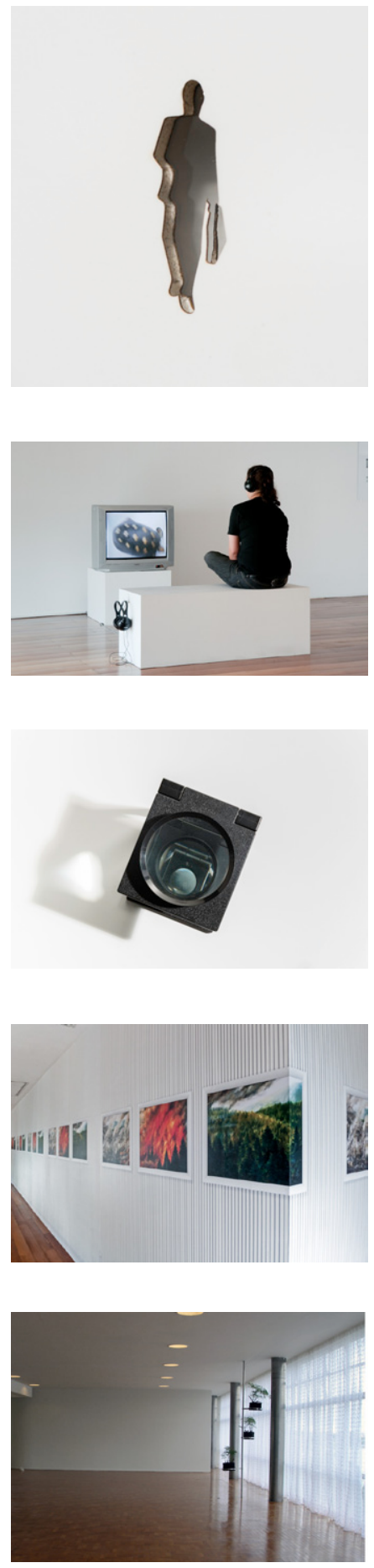
"Rodagem”, 2010

dois carrinhos de controle remoto modificados, mesmo

modelo, escalas 1:10 e 1:20; duas pinturas murais

realizadas sob encomenda

Instalação em duas salas contíguas da Galeria Mendes

Wood, São Paulo.

"Seu núcleo é constituído de ferro, níquel e talvez

enxofre", 2011

madeira entalhada

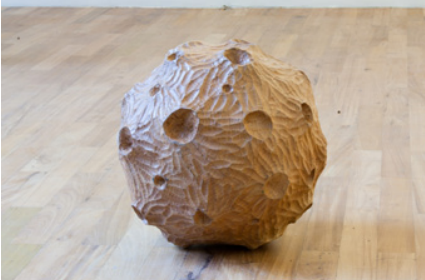

$45 \mathrm{~cm} \varnothing$

"Área, alcance, domínio, esfera”, Galeria Mendes Wood,

São Paulo. 